\title{
Metaphors and Space \\ Exploring the Life within the House
}

\author{
A thesis submitted to \\ the Faculty of Graduate and Post Doctoral Affairs \\ in partial fulfilment of the requirements for the degree of \\ Master of Architecture (M.Arch Professional)
}

Azrieli School of Architecture and Urbanism, Carleton University, Ottawa, Canada 2011 (c) Sarah Danielle Margreta Rogers 
Library and Archives
Canada

Published Heritage

Branch

395 Wellington Street

Ottawa ON K1A ON4

Canada
Bibliothèque et

Archives Canada

Direction du

Patrimoine de l'édition

395 , rue Wellington

Ottawa ON K1A ON4

Canada
Your file Votre référence

ISBN: 978-0-494-81656-1

Our file Notre référence

ISBN: 978-0-494-81656-1
NOTICE:

The author has granted a nonexclusive license allowing Library and Archives Canada to reproduce, publish, archive, preserve, conserve, communicate to the public by telecommunication or on the internet, loan, distribute and sell theses worldwide, for commercial or noncommercial purposes, in microform, paper, electronic and/or any other formats.

The author retains copyright ownership and moral rights in this thesis. Neither the thesis nor substantial extracts from it may be printed or otherwise reproduced without the author's permission.
AVIS:

L'auteur a accordé une licence non exclusive permettant à la Bibliothèque et Archives Canada de reproduire, publier, archiver, sauvegarder, conserver, transmettre au public par télécommunication ou par l'Internet, prêter, distribuer et vendre des thèses partout dans le monde, à des fins commerciales ou autres, sur support microforme, papier, électronique et/ou autres formats.

L'auteur conserve la propriété du droit d'auteur et des droits moraux qui protège cette thèse. $\mathrm{Ni}$ la thèse ni des extraits substantiels de celle-ci ne doivent être imprimés ou autrement reproduits sans son autorisation.
In compliance with the Canadian Privacy Act some supporting forms may have been removed from this thesis.

While these forms may be included in the document page count, their removal does not represent any loss of content from the thesis.
Conformément à la loi canadienne sur la protection de la vie privée, quelques formulaires secondaires ont été enlevés de cette thèse.

Bien que ces formulaires aient inclus dans la pagination, il n'y aura aucun contenu manquant.

\section{Canadä}




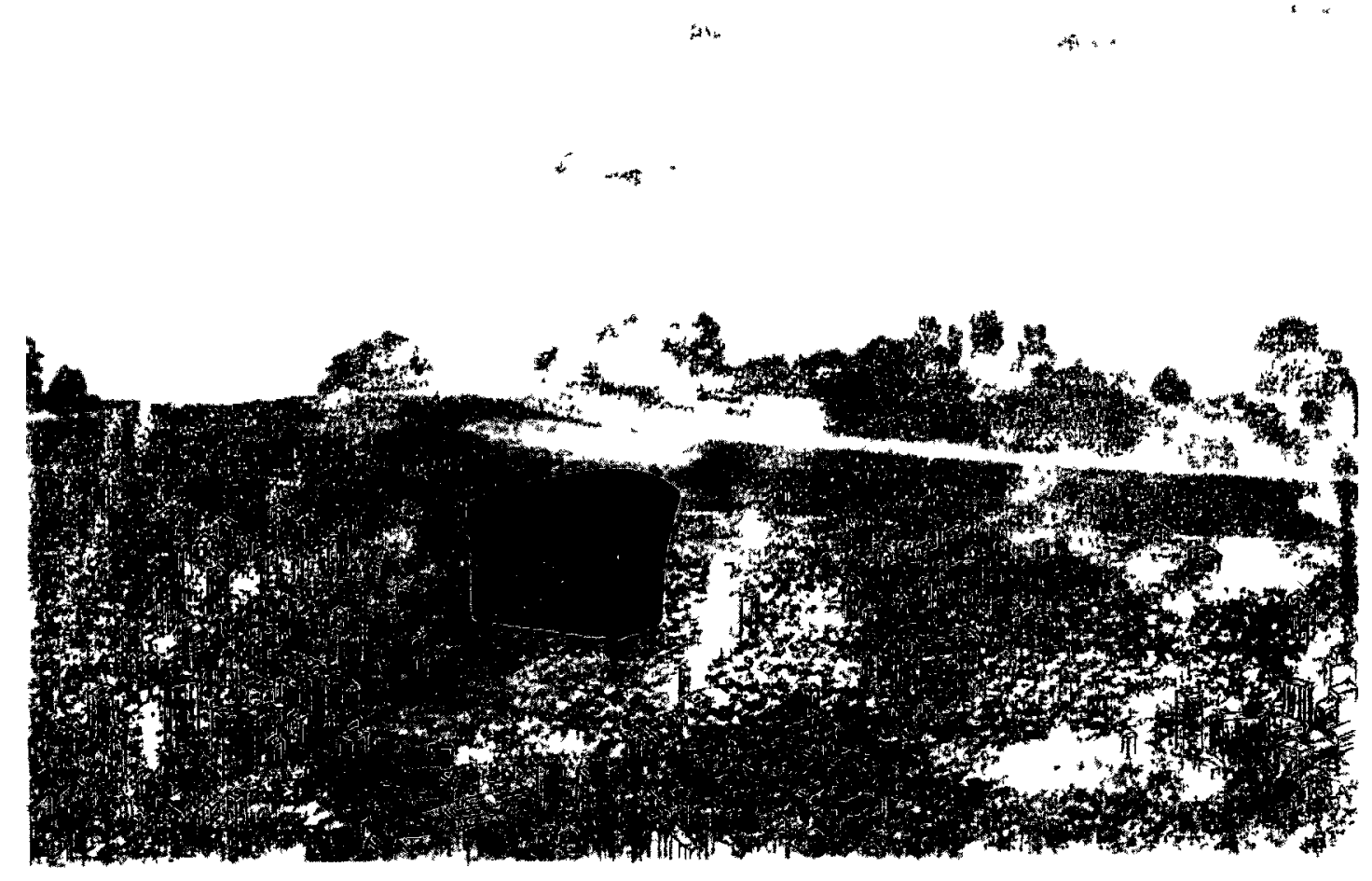




\section{Abstract}

As a place where we devote a great measure of our lives, the house is overlooked, for the intrinsic need of more housing and hurriedness of construction, at both the urban and suburban scales. The house is overlooked for what it really is, how it generates discourse, lives, and is recalled in memories, on a daily basis, and through our entire lives. Through the discovery of the phenomenological traits of the house, a new definition of the house arises, and demands a new approach towards the quality, and the arrangement of our lives within it. Shifting into the urban context, this new approach can be integrated to create density within the city, while creating discourse and life within the house. These discourses can emerge through the occurrences of space-metaphors as provoked through architectural expressions of form, light, arrangement, and materiality. 
To my family,

Who has only shown me love and support for all the endeavours I choose to take on To my boyfriend,

Who has stuck through everything with me, and has been my rock and strength when I needed it most 


\section{Contents}

Frontispiece

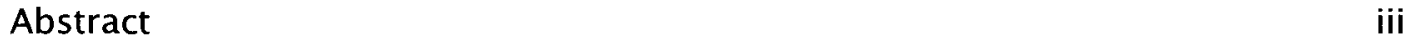

Prologue viii

Introduction iv

Chapter 1 The House 1

Chapter 2 Houses of Today

$\begin{array}{ll}2.1 \text { Suburban Houses } & 6\end{array}$

2.2 Apartment Style Condominiums 16

2.3 Urban Infill Houses 18

Chapter 3 The Space-Metaphor

3.1 Creating Space-Metaphors

3.2 Triggering Space-Metaphors

Chapter 4 An Urban Community

$\begin{array}{ll}\text { 4.1 The Story } & 56\end{array}$

4.2 Overview of Project 63

4.3 Church as Community Centre 67

4.4 Bed and Breakfast $\quad 70$

4.5 Commercial

4.6 Residential $\quad 79$

$\begin{array}{ll}\text { Conclusion } & 90\end{array}$

Appendix $\quad 93$

List of Illustrations 103

$\begin{array}{ll}\text { Works Cited } & 107\end{array}$ 
"In this remote region, memory and imagination remain associated, each one working for their mutual deepening. In the order of values, they both constitute a community of memory and image. Thus the house is not experienced from day to day only, on the thread of a narrative, or in the telling of our own story Through dreams, the various dwelling-places in our lives co-penetrate and retain the treasures of former days. And after we are in the new house, when memories of other places we have lived in come back to us, we travel to the land of Motionless Childhood, motionless the way all Immemorial things are. We live fixations, fixations of happiness."

- Gaston Bachelard

1 Bachelard, Gaston. The Poetics of Space. Boston: Beacon Press, 1969. pg. 5-6 


\section{Prologue}

Growing up with no siblings, and in a rural area where no friends lived close by, the house became my playmate. It echoed and listened when I talked to my dolls, my bears, and myself. It spoke and sang me to sleep late at night when everything was quiet and it even shared the delights of a thunderstorm from within its protective arms. By no means was this house anything out of the ordinary, but through the closets, the nooks, and the corners I developed a close relationship with it.

When I moved into an apartment in the city, it was not the same. With bare, flat walls, the qualities of the place remained hidden. It was not until another person moved in that the apartment began to show some quality. Due to lack of space, niches that were never needed before became places for shelves; every nook and corner was utilized. The need for more space, when none was to be found, forced an interaction with the space unlike before. This interaction between the space and myself brought about a transformation of the apartment. The apartment was no longer blank walls, but something more; the interaction had begun to bring it to life, and it became my home. 


\section{Introduction}

The exploration in this thesis emphasizes the qualities within the house that are seldom thought of as important. It sets out to discover their role in bringing the house to life. In the Poetics of Space, Gaston Bachelard introduces a new way to think about the 'house'; the house is not only able to adapt to the personal idiosyncrasies of the inhabitant, but also to the different manners in which the house influences the inhabitants ${ }^{2}$. For Bachelard, there is an intimate discourse between a house and its inhabitants. This discourse creates memories and hooks for other memories to hold on to. The house is not just a place that keeps you safe from the elements, but it is also a place for daydreaming and memory making. Consistent with Bachelard, Frank Lloyd Wright, sees the house as a place that should be our own little world. The specific qualities of the house form places of daydreaming and memories, and induce interaction and discourse between the inhabitant and their house. I argue that, while few consciously acknowledge this discourse, it is at the core of what we know as 'home'.

2 Bachelard, pg. vii 
With the hurriedness of construction, urban sprawl sweeping through the outlying city boundaries, and the diminutive scale of urban infill houses, the details of the house which cause this interaction and discourse may be overlooked, leaving houses lifeless. By analyzing urban and suburban developments, we explore whether current architecture of the house provokes, nurtures, and accentuates memories and interaction, or if the architecture fades into the background, rejecting interaction, and allowing memories to have been made anywhere. Though not all houses are completely lifeless, a lack of definition, or devices used, leave some spaces in a limbo state where they are can be neither dismissed, or interacted with, but rather a space that is just there.

A second analysis focuses on houses that possess character, and through this character provide not only the places for daydreaming and memories, but the ability to trigger other memories that add more meaning to a space. These spaces become space-metaphors, neither wholly imagined or built, but a hybrid of both. Each space has the potential for many different experiences since everybody has different memories that can be triggered. The space-metaphor, in conjunction with what we will define later as Character, creates spaces that are comfortable, meaningful, and unique, creating our own little world. At the urban scale, these space metaphors can be used to create spaces for daydreaming, and memories, that not only fit the redefined house, but still functions in a dense setting. 
The site that has been chosen to study the idea of the space metaphor is located in the Hintonburg neighbourhood of Ottawa, a pivotal community that is comprised of modest residential housing, and a traditional main street. While choosing programs that work with the existing composition of the site, (including a historic church) additional residential housing is designed to address the increasing density of the neighbourhood. Using Character to drive the design of the project, this thesis delineates the way in which the architecture of the house can facilitate, nurture, and accentuate our phenomenological experiences within. 


\section{Chapter 1 The House}

In the Poetics of Space, Gaston Bachelard describes a house as "an embodiment of dreams," with each nook and corner "a resting-place for daydreaming" ${ }^{3}$. Each room, or object, has the potential to transport you to another time or place. Something as simple as a scratch on the tip of a stair could take you back to a time when you fell down, landing on a similar staircase in your parents' home, possibly also reminding you of a favourite treat that cheered you up afterwords. Every part of the house has the ability to cause one to relive these memories. Bachelard extends this further to say that if a house "has a cellar and a garret, nooks and corridors, our memories have refuges that are all the more clearly delineated" ${ }^{4}$. The house is the backdrop for our memories, a place where we not only make memories, but a place where we are able to relive our memories, and our past. The backdrops for these memories are the walls, doorways, closets, and attics, which seemingly blend into the background of our everyday lives. Backdrops are accentuated and unambiguous when rooms are delineated from each

\footnotetext{
3 Bachelard, pg. 15

4 Bachelard, pg. 8
} 
other and desıgned for their specific purpose - for instance in a combined living and dınıng area. When dınıng is added to a living space, it tends to be an added extra couple of feet in a corner to accommodate a table and chairs. Nothıng separates the spaces. The furnıture is what delıneates it, whereas a separately defined living and dinıng space can accommodate not only their original purpose but also the nooks and corners that Bachelard refers to. When nooks and corners are created in the rooms of a house, they can be embellished to suit the needs of that specific room. a reading nook in a living space, or a corner that the dishes are housed In, these are the elements that make spaces more remarkable than a blank wall, or common piece of furniture. Each defining feature of a house is a hook that a memory can hold on to These definıng features can begin to work together to form the character of a house. A storage room under the stairs, in the eyes of a child, is not a storage room it is a fort a king needs to defend, while his queen waits for hım, the shelves, ladders leadıng to the highest tower of the lowest dungeon. In each new nook and corner is a new adventure, and the definıng features are the tools to create a world of ones own. It is through these defining features of a house that Character is formed and the life of a house can be delineated.

In the begınnıng of his career in 1894, Frank Lloyd Wright introduced ideas of what circumscribes a house, ideas which he contınued to argue for the rest of his life. In Wright's paper, The Architect and The Machine, he states that the home is "our own little world withın the great world - for every man's home should be that to hım"5. He attempted to incorporate this idea in all of the houses he designed. This begs the question - what is our own little world and how is a house able to provide us with our own little world? Our world provides the essentials of what we need, a place to eat,

5 Wright, Frank Lloyd, and Bruce Brooks Pfeiffer Frank Lloyd Wright Collected Writıngs New York 
sleep, cook and other basic human needs. But our world needs to incorporate our nonessential needs as well. These are the various activities and objects that make us happy and most comfortable. If these needs are met within the house, then our house is our world, and as such, provides us with what we need as individuals.

Character, Wright explains, is "individual significance" and "the result of nature expression on the soul of life-principal of anything 'organic' whatsoever - to the degree that the idea or life-impulse achieves consistent form to our senses" ${ }^{\prime 6}$. Building on Wright's definition of character, we can begin to define the character within the house. A stone with a crack may be said to have character, but when built into the wall of a home, it is only one of many integral parts that contribute to the character of a house. The character of a house is made up of many components such as materials, form, arrangement, and lighting. Each singular component has the potential to contribute to the overall character of a house, and only then, when all the components work and meld together, is the character of a house clearly defined. Therefore, it is not just one characteristic, but the conglomeration of many different characteristics that play off of each other to develop the whole character of a house. While the concept of character is straight forward, the interaction between the inhabitant and the character of the house gets complicated. For each individual, the characteristics of the house change, and the spaces are manipulated and adapted to the inhabitant. These unique and defining features are what begin to create an interaction and discourse between the inhabitant and their house.

The character of a house, as previously described, is formed by components that are

6 Wright, pg 268 
unique unto itself. Though some of these characteristics will come in the form of texture, smell, and sound, the main form of expression of a house is its appearance. Since appearance is also associated with style, we must be clear on how character and style are dissimilar. Wright describes the difference between character and style as "the difference between truth and beauty."' To be beautiful, it is not always possible to be able to show everything. Sometimes it is necessary to keep hidden something that does not fit in to the whole design in order to make it beautiful. Whereas with truth, you do not hide anything, you show everything. The same applies with character and style. A stylistic design is a design that follows a specific set of rules, and will hide anything that does not fit within those rules, because if it did not, it would not be beautiful in the context of the style. But a truthful design, takes the natural way things are and works with that to create a whole - this is character. Truthful design does not lie about what it is or is not, nor does it make people think it is anything other than it is. It is honest and does not deceive. It is true then, that not all character will be beautiful, but, in its own way, it is beautiful because it is truthful. So, it is for this reason that it can be very hard to tell if a house has style rather than if a house has character. Many market driven houses of today are built in a particular 'style' but this does not necessarily mean that the house has a character. These styles are just illusions that allude to individuality, uniqueness and character, but in reality, it is common with no character, and no life. Styles in a house, when they are a consequence of character, do provide life in a house, but styles that are not a result of character are frequently used as a disguise.

Though the character within a house can form an interaction and discourse between the inhabitant and their house, Bachelard views that the interactive role between people and

7 Wright, pg 268 
their house starts from the very beginning of our lives:

In the life of a man, the house thrusts aside contingencies, its councils of continuity are unceasing. Without it, man would be a dispersed being. It maintains him through the storms of the heavens and through those of life. It is body and soul. It is the humans being's first world. Before he is "cast into the world," as claimed by certain hasty metaphysics, man is laid in the cradle of the house. And always, in our daydreams, the house is a large cradle. A concrete metaphysics cannot neglect this fact, this simple fact, all the more, since this fact is a value, an important value, to which we return in our daydreaming. Being is already a value. Life begins well, it begins enclosed, protected, all warm in the bosom of the house ${ }^{8}$

From the very beginning a house shelters, and keeps us safe. That alone, makes it significant in our lives, and according to Bachelard, this significance is realized right from when we were a child. This significance of a house can be translated into a special sense of belonging to something. Just as a child will belong to its mother because she will look after him, so too can it be said about a house. Wright states that "people should belong to the building just as it should belong to them"'. Though Wright is using this as a reference to the scale of the building, it can also be expressed as the phenomenon of actually belonging to a place. Through the character of a house, you begin to get the feeling that the house is really just an extension of yourself, it is there when you need to be by yourself and provides a place where you can retreat to. It is a place to keep all of your precious items, as well as a place that encompasses what you need to feel safe and secure - it's a soft place to fall.

\footnotetext{
8 Bachelard, pg. 7

9 Wright, pg. 250
} 


\section{Chapter 2 Analysis of Suburban and Urban Houses}

We spend a lot more time in a house than we realize. We sleep, eat, and relax after work. On days we feel lazy and frequently on holidays and weekends, we spend our time in the house. The house is our own little world that we can withdraw into, and invite others into. It is a way to show ourselves visually to our friends, family, and new acquaintances. As discussed in Chapter One, there are key aspects of a house that must be present in order for the life of the house to emerge. The house is a backdrop for our memories, and as such, needs to delineate our daydreams and memories. It is through these unique features, generated by arrangement, materiality, form, and lighting, that the character of a house is created, and consequently, through our interaction and additions to the house, the life within a house is created.

\section{Suburban Houses}

The development to be used for this analysis of market-driven suburban homes is the Jackson Trails Community, located in Stittsville, a small suburb of Ottawa, Ontario, developed by Tamarack and Tartan developers in 2006. Boasting over forty different 
floor plans between the two developers, the community provides

...spacious front porches [that] draw people from their homes to enjoy the outdoors; recessed garages [that] will lend the feel of openness to the community and reduce the dominance of the automobile; [and] sidewalks [that] will encourage residents to stroll the neighbourhood, mingle with neighbours, visit a playground area and connect with a network of recreational pathways. ${ }^{10}$

Though no doubt street life and the community aspect of this neighbourhood was an important consideration in the development of Jackson Trails community, it is the interior that we spend most of our time. The attention to detail of the interior is what can create a life within a house, and as such, allows for a discourse between the house and its inhabitant.

\section{Analyzing Floor Plans}

The floor plans for houses of Jackson Trails show the organization of the house. After a basic analysis of the 47 available models for the community, the following conclusions can be made:

1) As the house gets smaller (from 3500 to 1400 square feet) the first room to be cut out of the ground floor plan is the living room. This shows that the house is increasingly becoming more private.

2) Most homes have the kitchen and dinette open to the family area, in an open concept plan, and depending on whether there is a living room or not, the dining room is often open into the family areas.

3) When the houses reach approximately 2000 square feet, the number of bedrooms typically decreases from 4 to 2 . Of the total number of homes, two

10 "Jackson Trails." tamarackhomes.com. Tamarack. n.d. Web. 2 March 2011 
thirds of them have 4 bedrooms, some also have the option of adding a fifth bedroom.

4) Most family rooms, and kitchens are pushed to the back of the house, while the living rooms and dining rooms face the street. When the house is smaller, usually influenced by a narrower lot, only the garage and foyer front the street, with 'proper' areas in the middle and the family room and kitchen in the back.

Though there are a total of 47 different models available in the Jackson Trails community, all can be found in other communities in and around the City of Ottawa, and are not unique to the Stittsville area. Significantly, 31 of the 47 models have a minimum of 4 bedrooms, and therefore the majority of the homes are very large. According to the 2006 Canadian Census, there were a total of 449,300 households in the Ottawa-Gatineau region. Of these, 314,310 were families, of which 16 percent were families with 3 or more children. The average number of children per home in this region in 2006 was 1.1 children." This is reflected all over Ontario, with an average of only 1.2 children per home. ${ }^{12}$ According to this data, 16 percent of families in the Ottawa-Gatineau region are served by 66 percent of the homes designed today, while the other 84 percent of families are expected to choose from the remaining 33 percent of homes designed for the smaller family. For the above reasons, this ultimately means that many families will choose a house larger than required, or if only the smaller houses are built, the community will not have a variety of housing designs.

11 Statistics Canada, 2006 Census of Population. Catalogue no. 97-553-XCB2006007 (Ottawa-Gatineau Code505)

12 Statistics Canada, 2006 Census of Population, Catalogue no. 97-553-XCB2006007 (Ontario Code35) 


\section{Analyzing the Model Homes}

Keeping in mind that a model house does not actually have a real family or individual living in it, it should still have a character that one can feel and begin to have a discourse with. Out of the 47 possible homes in Jackson Trails, 6 model houses were featured: from Tartan, the Royal Edward, the Beckwith, and the Lindsay; and from Tamarack, the Oriole, the Bristol, and the Dorset. Of these, the Royal Edward is the largest at 3,231 square feet, the Beckwith, Dorset, and Bristol are approximately 2,400 square feet, and the Lindsay, and Oriole are the smallest, at approximately 1,600 square feet.

The Royal Edward (III. 1) being the largest of the group, has 4 bedrooms, a loft, study, sun room, joined living and dining area, 2.5 baths, as well as a family room. Each room has ample space, and, of all the model homes, has the most character. The character in this house is created by the use of form, arrangement, and lighting to create specific atmospheres. Starting in the living room, a two-story height, there is a curved stair that defines it as a separate entity from the hall way, and at the second floor height there is a detail that allows for artwork or special family heirlooms to be displayed (III. 2). The form of the stair and the double height ceiling shows off the area as a special place and create a strong, yet cozy space, as the stair gives the illusion of wrapping around you. In the dining room, atmosphere is created by three highlighter windows that are placed close to the ceiling. As these windows lead into the sun room, the light entering into the dining room is soft and subtle. The kitchen and family room are separated by half walls, allowing the spaces to be separate but at the same time keeping a visual connection to each other. The use of the half wall also creates a nook, (denoted as the breakfast area on the plans) which allows for a place to get away. The sun room is also a nice place to 
retreat to (III. 3). At the top of the stairs, there is an open landing which can allow for a further getaway without completely removing yourself from the rest of the house. It is a space that can convert to anything, from an office, to a play area. With the view down Into the living area, thıs space is a great place for kıds to ımagıne in. Unfortunately, many of the materiality and lightıng features, such as the stone fireplace in the family room, and pot lights are an upgrade in this home. As such, this means that the atmosphere that the materials and lightıng create cost more money than the base price of the house. The fireplace Itself, though presenting the idea of a strong element in the family room, is false, not structural, which effects the integrity of the house. The Royal Edward is the only model home that has every single upgrade avallable. This makes it tougher to see the true architecture The architecture has to be even more pronounced to be able to show itself through all the 'make up' that is put on it. The make up itself can be considered the style. It consumes the visual of the architecture to hide what the architecture really is.

In the middle range houses, there are still 4 bedrooms, and each home has a study on the main floor, though it is at this point that the houses begin to join rooms together. This happens in the Bristol by Tamarack, combinıng the family room and dinıng room Into one large space. The 'open concept' plan that is shown here (III. 4), though great for social relatıonshıps, provides few areas to place furniture agaınst, places to remove yourself, or niches for daydreamıng. The Dorset on the other hand, does the exact opposite. It has a fairly closed plan and offers many opportunitıes for a niche, or special features to be used, perhaps built in shelving in the wall. Unfortunately the walls are left bare, naked, unrealized, and unused. The Beckwith model attempts some play with the walls between the kıtchen, family room, and dınıng room (III. 5), using half walls, and a 
window from the family room to the kitchen to gives you a line of sight. In the living room, the necessity of the bulkhead is turned into a little niche for a couch, which begins to add some depth to the otherwise flat walls. Upstairs, two of the three bedrooms take into consideration a nook as a place for a particular purpose, in this case a desk area (III. 6). This nook in a smaller children's bedroom allows for a space that could be for painting, creating, reading, or dressing up in.

The last two homes, which range in the 1600 square foot region, noticeably have spaces that get even tighter and lack even more character than found previously. The Oriole, which takes the form of a bungalow, separates the dining and living area from the family areas using the kitchen (III. 7) and creating a long space down the length of the building. Though noted as a sun room, when extended outwards (as the model has done) it becomes the family room nestled behind 2 sets of doors from the kitchen. This is a unique way of keeping the family areas visually together with enough of a separation that different activities could be performed at the same time. The Lindsay on the other hand, is a two story home, keeping the social places on the main level, and bedrooms upstairs. There is not a separate formal living area, but the dining room is separated spatially with an archway and column, leaving it open for conversation, while giving the feeling of being in a different space. Similarly with the breakfast nook, the ceiling is raised to give the feeling of a different space from the kitchen. In both houses many of the rooms are constructed as squares and rectangles, with little definition.

It is noticeable that as the houses get smaller, the spaces are not as delineated or detailed as the larger houses. Understandably, the smaller houses have fewer rooms to delineate and detail, but rooms such as the dining and family area, the kitchen opening 
Into the famıly room, and the lack of 'formal' lıving room can provide more opportunities to be creative in the combinations of rooms, how they come together, and how they are delıneated in a way that works well for the inhabıtant. In thıs way, form, materiality, arrangement, and lightıng contribute substantıally to the indıviduality of the house which creates a harmonıous character. Then agaın, large houses, lıke the Royal Edward, do not have these opportunities of creativity because they have walls separatıng most of the rooms. At the same tıme, this provides an opportunity that the suburban house does not often take: detailing walls and using them to add to the character of the house.

Therefore, both large and small houses have opportunities that are not capitalized upon, and a potential character which is not given the opportunity to show itself. 


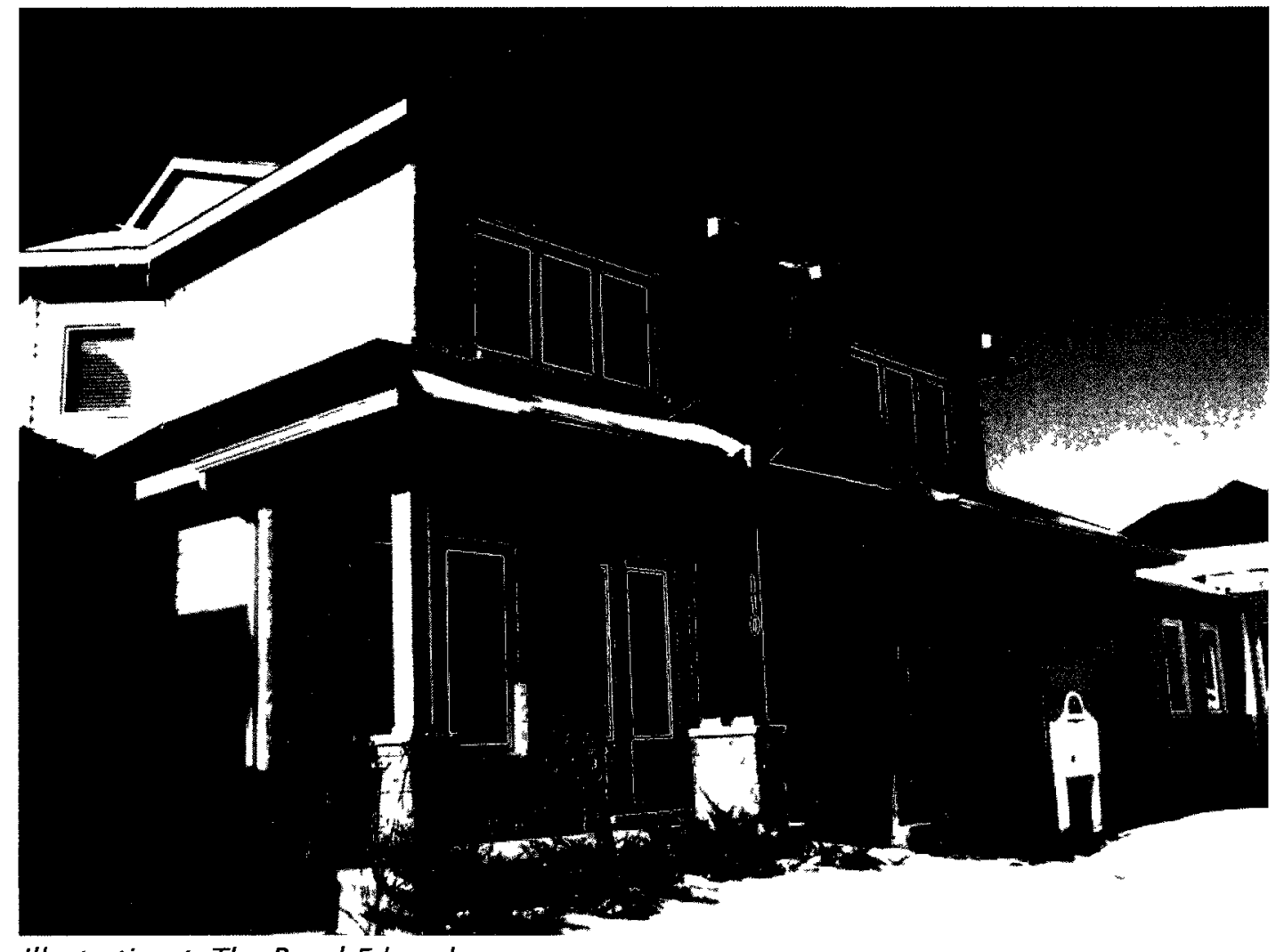

Illustration 1: The Royal Edward

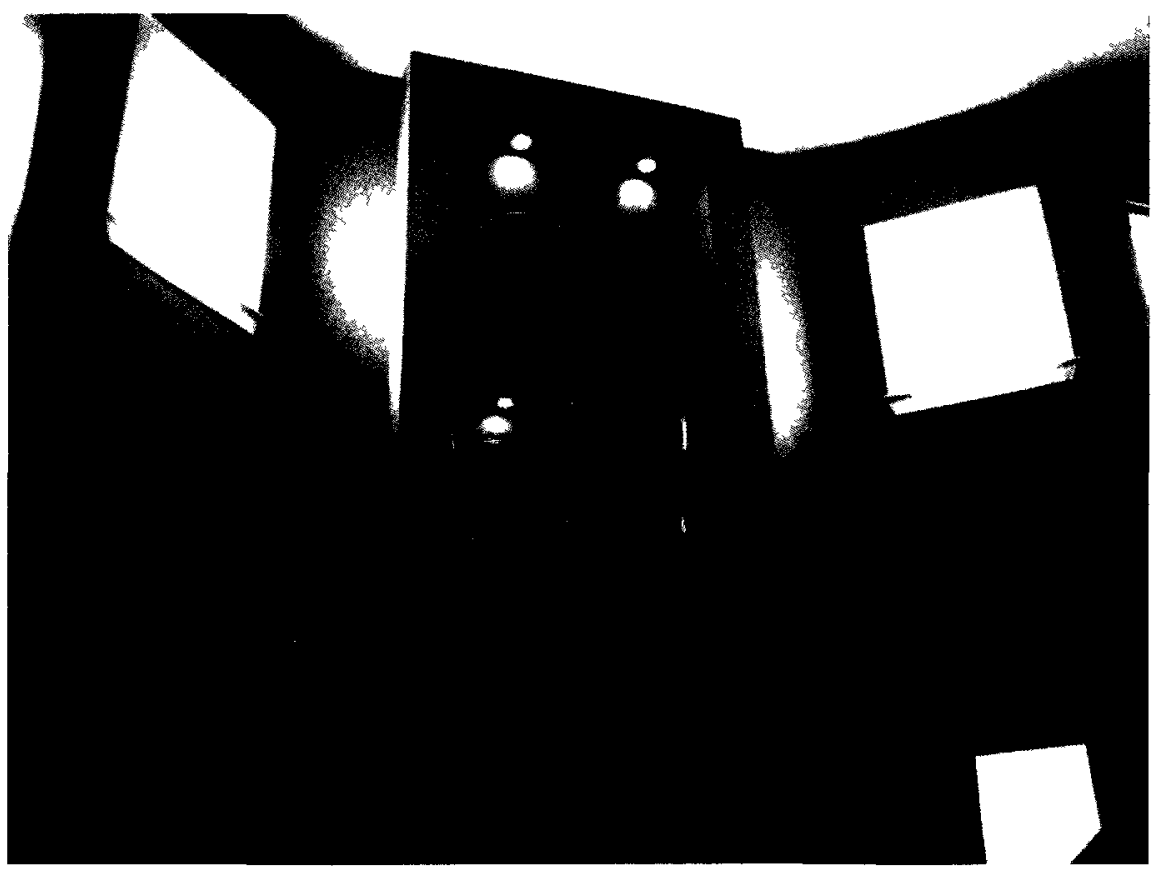

Illustration 2: Drywall framing detail in living room 


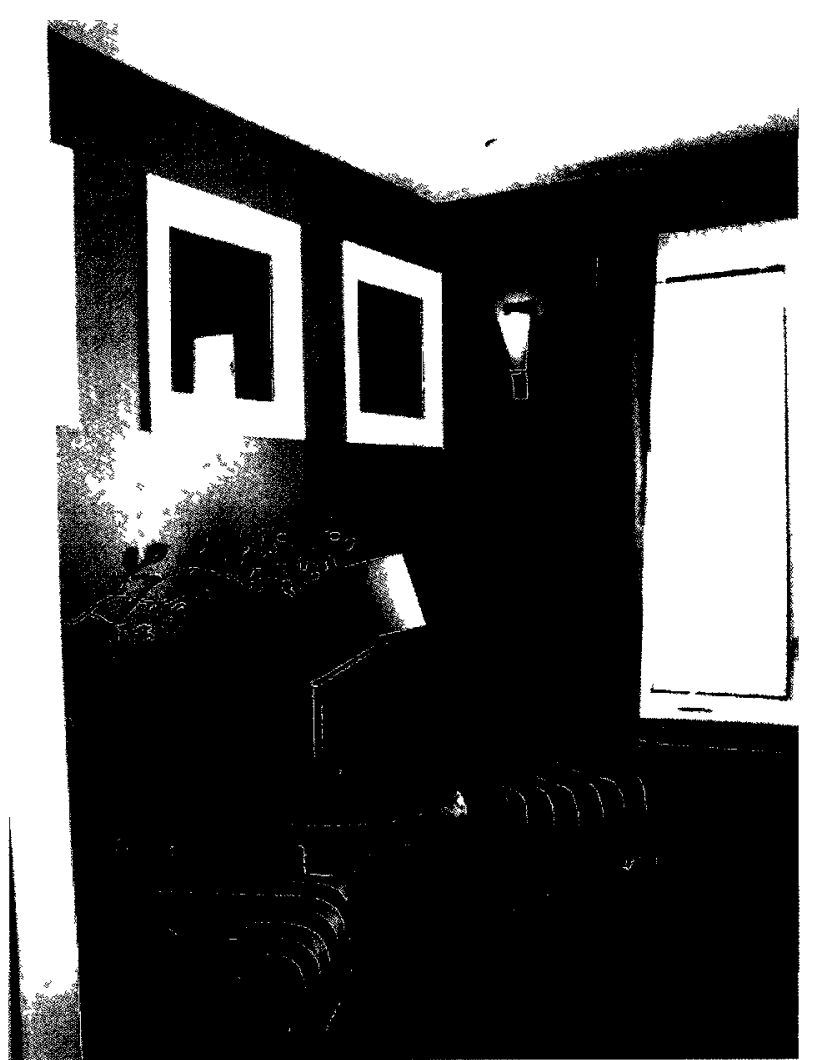

Illustration 4: Sun room, windows above chairs lead to dining room

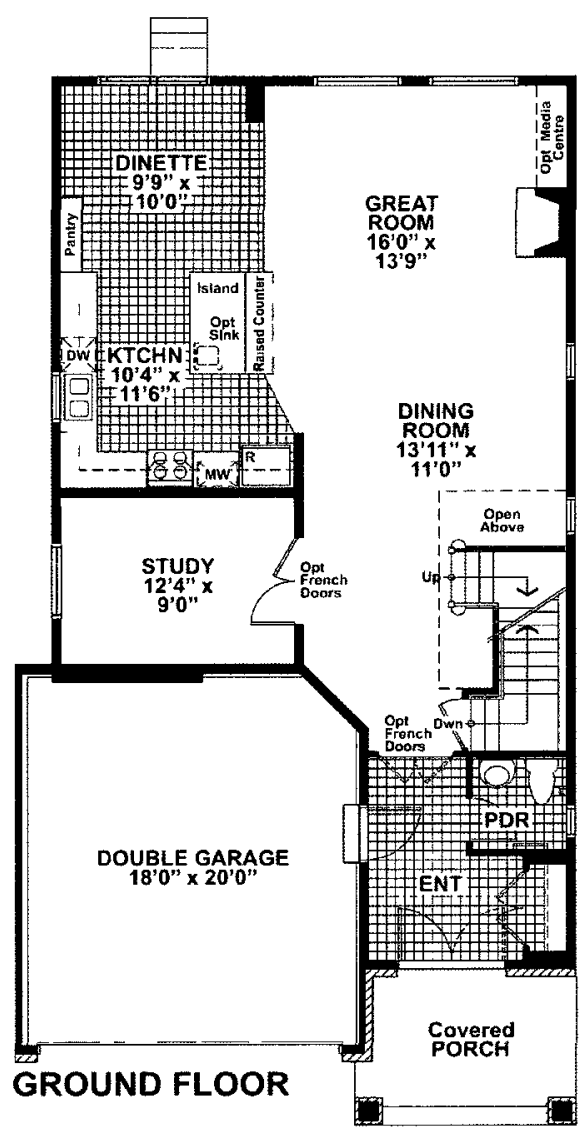

I/lustratıon 3: The Bristol, ground floor plan

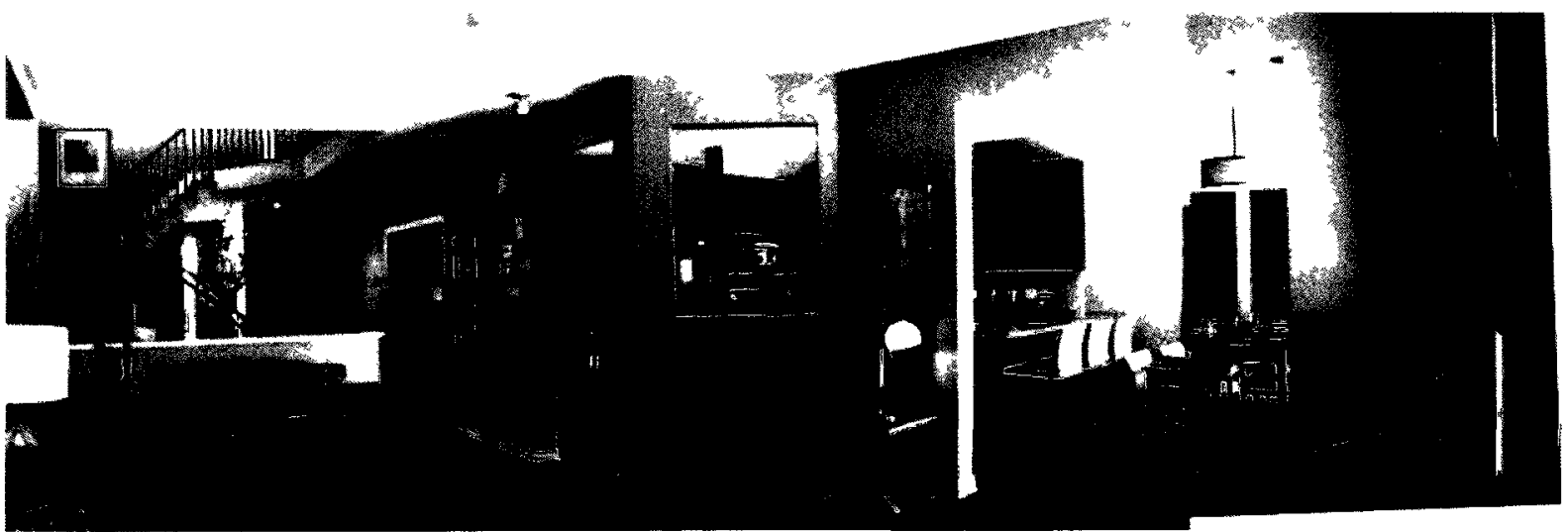

IIIustration 5: Beckwith, lookıng from family room to dınıng area (In front of stairs), kitchen and dinette 


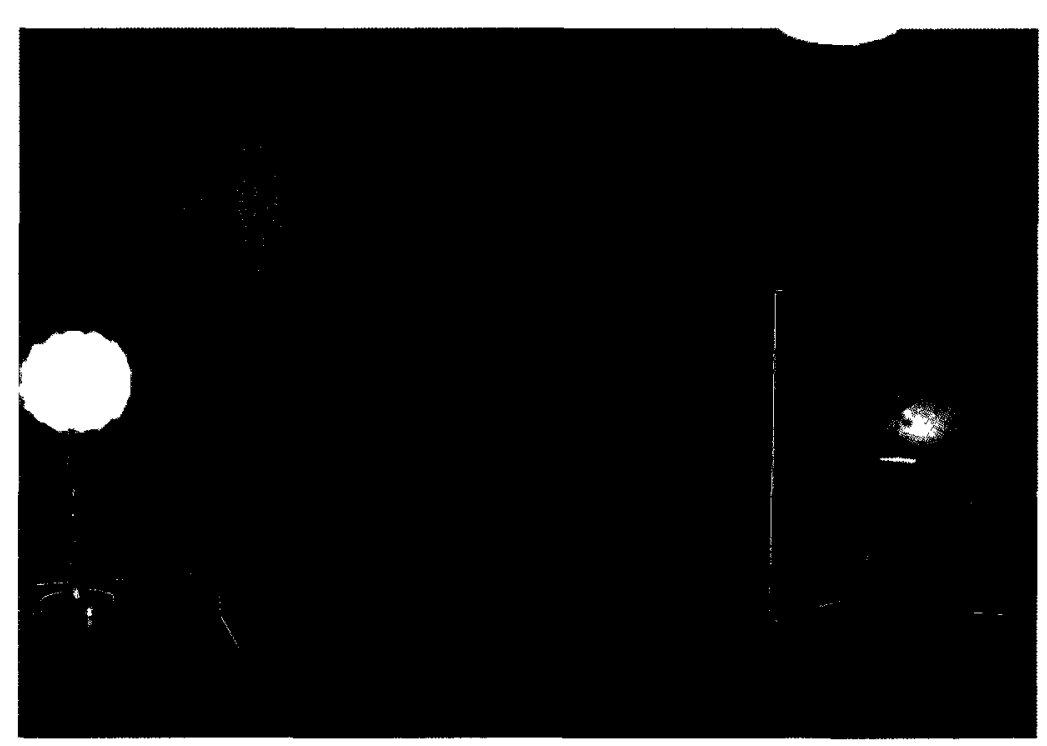

Illustration 6: Nook in childrens bedroom

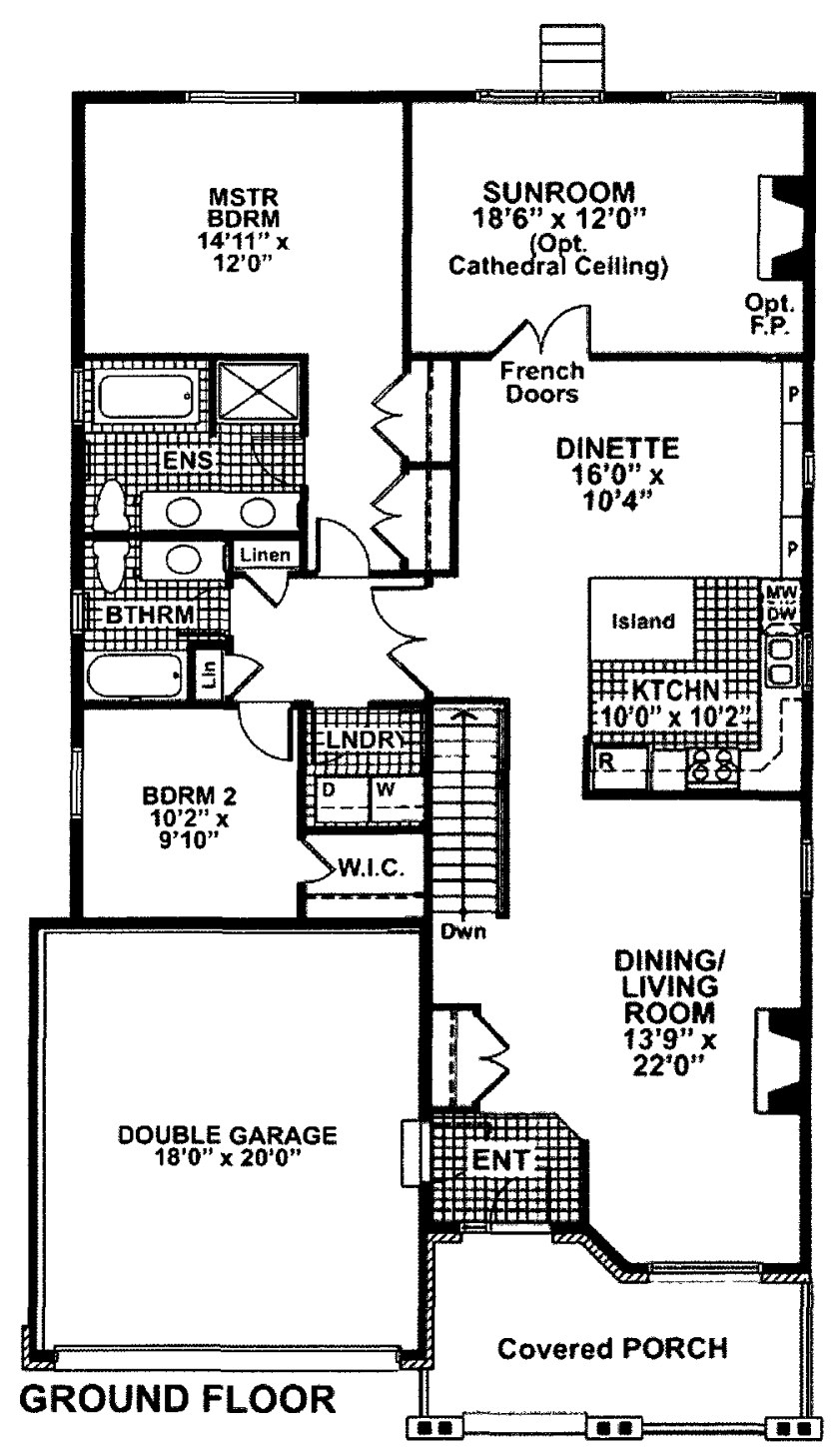

Illustration 7: The Oriole, ground floor plan 


\section{Urban Houses}

\section{Apartment Style Condominiums}

Though apartment style condominiums are not a typical 'house' they are still spaces that can take advantage of the concept of character to create an interaction with its inhabitant and convey a life through the architecture. One such new condominium development is hōm, developed by Domicile Developments (III. 8). Analyzing the apartment style condominium is different than analyzing the suburban house, as many of the units are bought before a layout can been seen, but similar 'styles' of layouts are shown so one can extrapolate the spaces into the desired or chosen floor plan. Each floor $(2$ to 10 ) has 11 layouts which consist of 2 two bedrooms plus den, 3 two bedrooms, 2 one bedrooms, 3 one bedrooms plus den, and a single bachelor unit. Out of the eleven typical floor plans (III. 9) (excluding penthouse suites), hōm has two suites modelled in their showroom. Neither unit were made as they would be seen when built, as ceiling heights were not shown, some walls were omitted to allow a potential buyer to flow through the show room. Over all, the way that Domicile represented their units gives the buyer a general understanding of the size of the spaces, and how they are put together. As there are no unique features such as the framing detail above the fireplace in the living room (III. 2) in the Royal by Tartan, any nook, corner, or niche in these units can be seen in plan view

The two units built in the show room were the 01 suites (III. 10) and the 02 suites (III. 11). Beginning with the 01 suite, it is 977 square feet, with two bedrooms, and two baths. 
The living, dining and kitchen area are one large room, with a bedroom exiting from the kitchen, and another from the living room. Only one of the five units that have two bedroom (with or without a den), the 09 suites, have both bedrooms together and separated from the rest of the apartment. In apartment houses space is so valuable that a hallway can be seen as wasted space. Though this is not a traditional way of organizing a layout for a single floor house, it is one solution to eliminate the wasted space of the hallway. Unfavourably, this means that there are not private and public domains, and forces the whole house to become private. In this particular suite, there is a slight separation in the living area which creates a nook for a single chair (III. 12). Unfortunately this nook is very small and seems to limit the size of the living area to that one corner, while the dining area is very prominent and a large table can be accommodated (III. 13). Though this would be a very suitable place for entertaining guests, the lighting and character around the dining area do not enforce this idea. If this were an apartment that would accommodate a lot of entertaining, a couple of conceptual ideas would be to have a sliding partition between the living and dining area to keep the space intimate, or provide special lighting to keeps the dining area lit, while diminishing the presence of the other rooms. This can be achieved by the application of dimmable pot lights around the dining area. While set low, they define the space in use and make it intimate. A second feature that could be added to solidify the concept of entertainment is using built in shelving or creating special nook for the glassware and plates. The nook would become a showcase for the dishes, while allowing ease while putting them away constantly, or taking them out.

The second unit modelled was a one bedroom apartment, with den. At 781 square feet, this apartment only has one oversized bathroom with two entrances, joining the den and 
the bedroom (III. 10). By designing the washroom in this configuration, it becomes the main bathroom as well as an en suite bathroom. Unlıke in the 2 bedroom unit, the protrudıng column in the lıvıng room and kıtchen/dınıng space proportıons each space equally, netther one overshadowing the other. Though proportioned equally, the blank walls leave much to be desired (IIl. 14), and do not promote a discourse or provide opportunities of daydreaming in a nook. In small spaces like these, it is necessary to include niches, nooks and corners to delineate the spaces but also to provide the opportunities of the architecture transformıng into furnıture, instead of addıng more furnıture and makıng the space smaller than it is. When the architecture begins to become part of the furniture it not only begins to create a discourse with the inhabitant, but it also begins to include spaces for the non-essential activities that we need in our own world as well.

\section{Urban Infill Houses}

Simılar to condominiums, the urban infill projects analyzed were also bought before they were built. Though not all houses are bought before construction, small developers generally need some of the units to be pre-purchased to finance the construction, therefore not allowing the buyer a chance to see the types of spaces that they will be living in. Three different infill projects will be used in this section of the analysis, each which were suburbs, but over many years, the area has been annexed by the city and has become urban, and in need of densification. Located on Illustration 15, the three separate sites can be seen, 224 Royal Avenue, 171 Carleton Avenue, and Armstrong Street. 224 Royal is a single semi-detached house, whıle 171 Carleton incorperates two semı-detached houses, both designed by Hamel Desıgn. The Armstrong development, 
designed by James A. Colizza Architect Inc., combines 4 single houses, and a double on the site. While 224 Royal has had an inhabitant for ten months, the other two sites were still under construction.

Starting with 224 Royal (III. 16), this house uses the open plan concept for its main floor, combining the kitchen, family, and dining rooms, 3 bedrooms and a den/office on the third floor, and recreational room in the basement (III. 17). The open plan on the main floor does not allow for nook and niches, it does begin to allude to a discourse, but a quiet one that is not being heard. Firstly, behind the couches, the wall is sunken in a little, and formed on the other side by the cabinetry of the kitchen, forms a niche about twelve inches deep (III. 18). The inhabitant have placed a large painting there that fit well, but as the couch is facing away from this niche, the space becomes circulation, and greatly underused. The stone column which the living room couches are focused towards, though a large form in the area of the living space, when combined into the other rooms becomes less of an element and tends to blend into the wall. This is also emphasized by the fact that the windows are similarly large, and the mass of light coming in and the mass of the stone element conflict with each other (III. 19). On the upper level, the den becomes a niche to retreat to, while the double height bathroom gives one a completely difference experience. In the master bedroom varying ceiling heights delineate the bed space, with circulation space, and create unique spaces for storage, or showcasing of personal items (III. 20).

171 Carleton and the Armstrong development, though under construction, allow a unique opportunity to view architecture at its rough stages, before it is painted and furniture is placed. At this stage in construction, the architecture should be fully able to show itself 
without competing with furnishings and decoration. Each of the four units at 171 Carleton Avenue, has exterior sımilarities to 224 Royal, and use many windows in the stairwells to bring light into the centre of the house (III. 21), and corner windows to extend the interior spaces outwards (III. 22). In one of the units though, a very unıque and 'fortunate accident' occurred around the fireplace. The initial plan had a regular enclosed fireplace in it, but with the addition of the window, and excess piping that was not taken into account in the initial desıgn stages, the fireplace evolved into a piece that is promınent in the design (III. 23). With the unique 'c' shape of the drywall formıng and enveloping the fireplace, and the bench that starts at the end wall, intersect with the fireplace, and contınues on for a couple more feet (stoppıng at the dinıng area), this single element can spawn many different types of discourse and allows the inhabitant to interact with it in many different ways. By including a covered roof terrace (III. 24), another room is created that increases the chances for more discourse, this time with the exterior architecture.

Lastly, is the Armstrong development, desıgned by James A. Colızza Architect (III. 25). This site is comprised of 4 single houses, and a semI-detached house (III. 26). In the singles, the quality of light that comes into each unit gives them a lightness. Corner windows are also used in this design to make the spaces seem larger. Though not many, there were a few special characteristic of the houses that began to create a discourse. First was the use of the open closets (III. 27). Though sımılar to a regular closet, these ones were open to either hallway or adjoinıng rooms to bring more light into the centre. The ledge created by this void is where discourse can begin, and snippet of view can be caught leading to a curiosity of the spaces beyond. The arrangement of the rooms, and the layout of them lead to some interesting view across the whole space alluding to a 
larger space as well (III. 28). In one of the semi-detached houses, a portion of the kitchen which is full height, with an office/den above looking into the double height space (III. 29). The other semi-detached unit, uses interior windows to generate interaction and glimpses between spaces (III. 30).

Though the new urban houses did portray more definition, and character in the interior, than the suburban house, there is still not enough character to create a cohesive whole. The characteristics are fragmented and are few and far between. In a larger house, there are more opportunities for unique characteristic, while in a smaller house, the characteristics should be more defined to create a stronger impact. One common feature of all of the houses was the drive to provide large windows and lots of sunlight. While this is good, it is not always beneficial for all spaces and their activities. Light, like the dimensions of the room, needs to be tailored to the activity, and the inhabitant. As a special place, a world of our own, it is key that the house and its inhabitant should not only be and provide the essentials but enhance the experiences of being home. Through the character of the house a discourse between the house and its inhabitant develop, allowing for daydreaming, resting places, places to retreat to, and vibrant memory backdrops. The characteristics of the houses will stay with us as memories that will be brought back to the surface of our minds at another time, when another space reminds us of them. The link between the two spaces form the discourse with the architecture, which we can consider to be space-metaphors. 


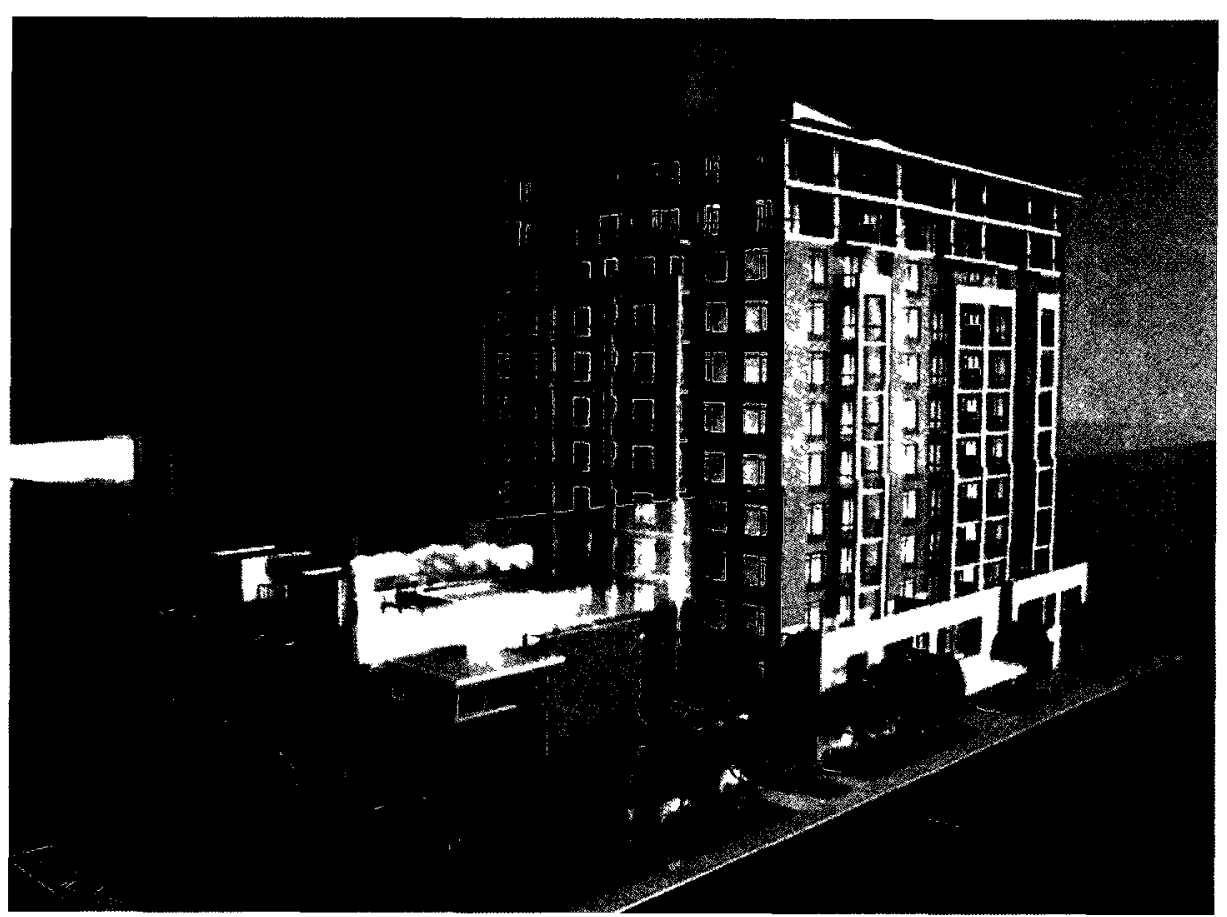

Illustration 8: Scale model of Domicıle development hōm

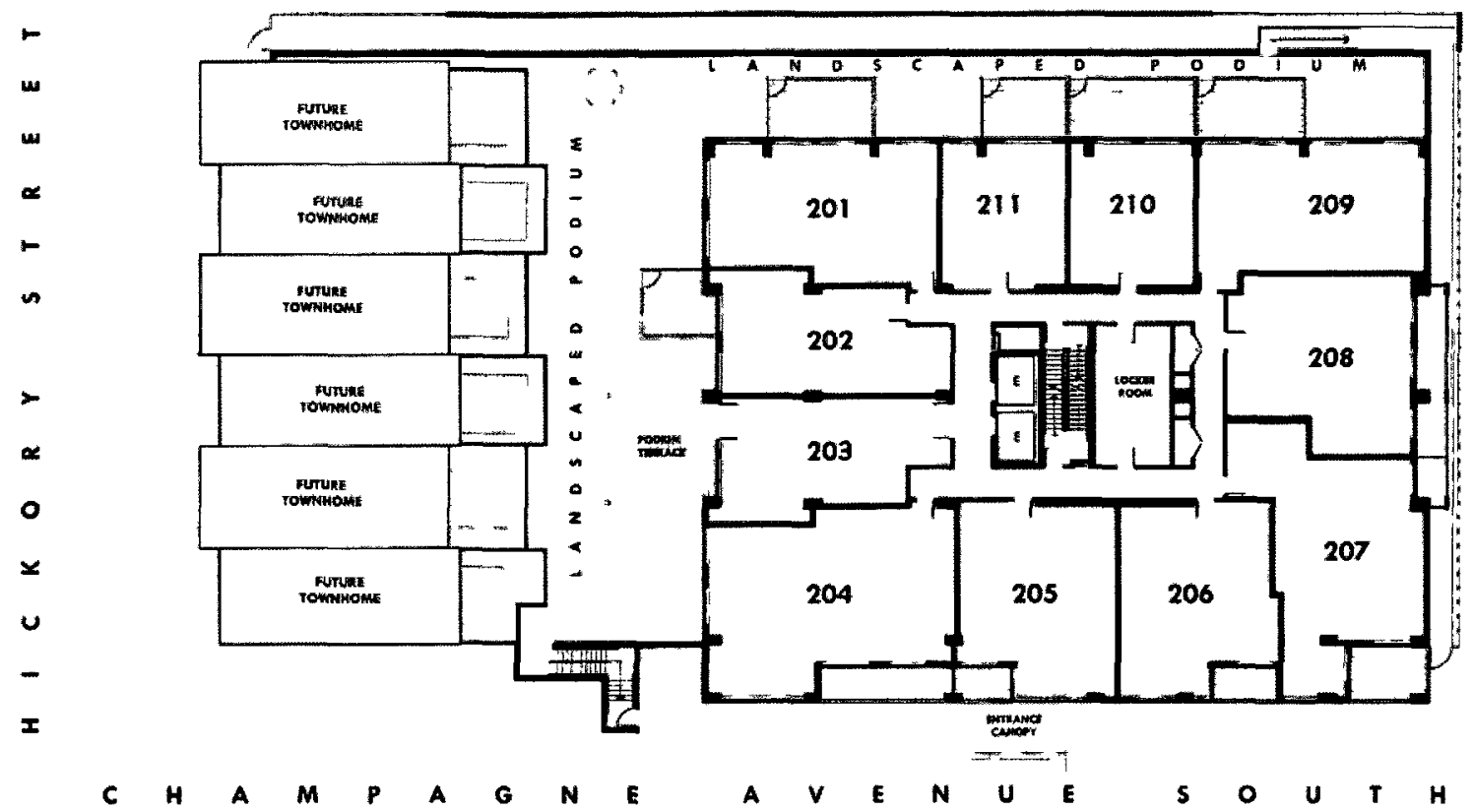

Illustration 9: Typical floor layout with 11 different units 


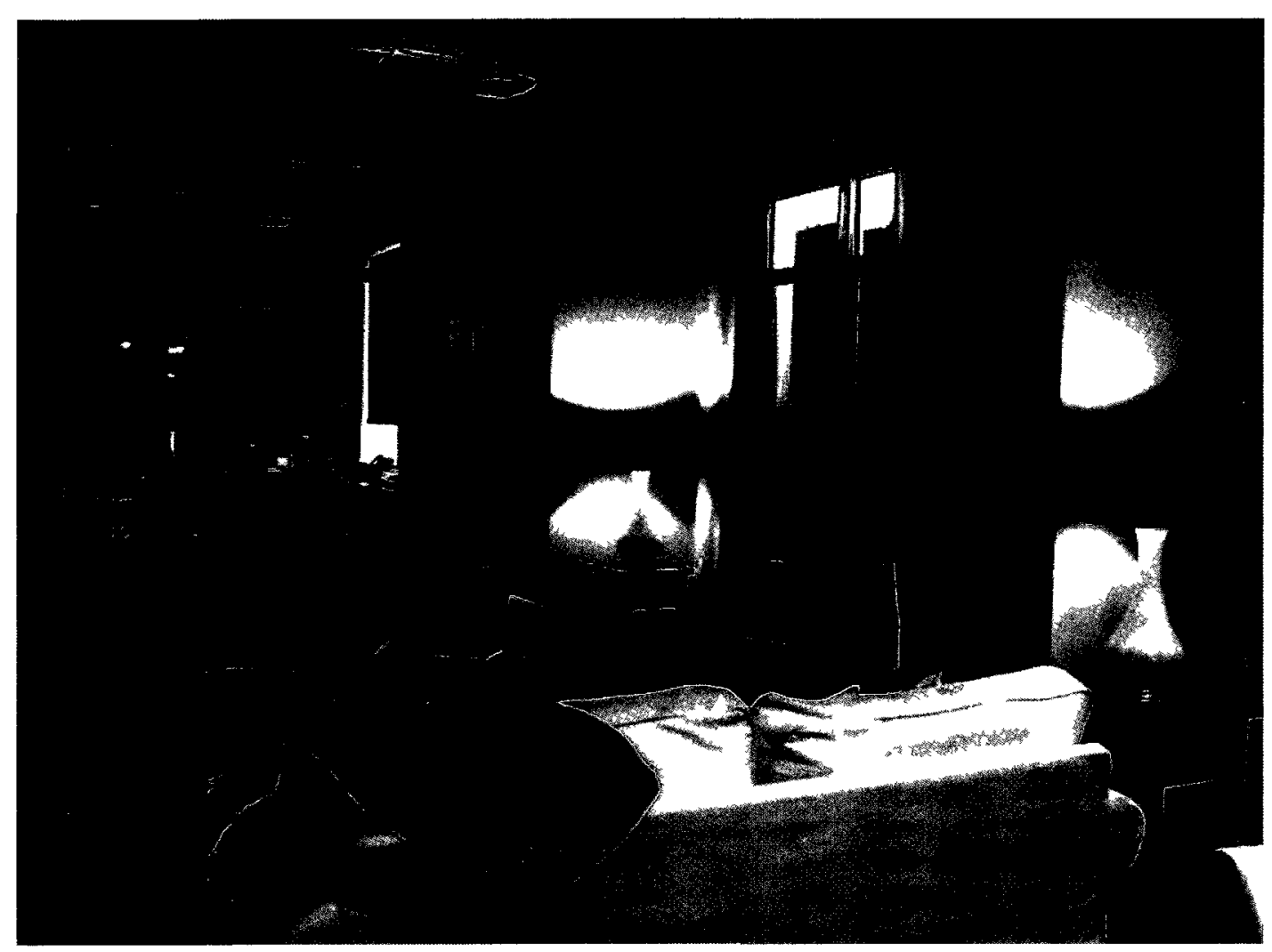

Illustration 12: LIving space of an '01' surte, nook for a single chair

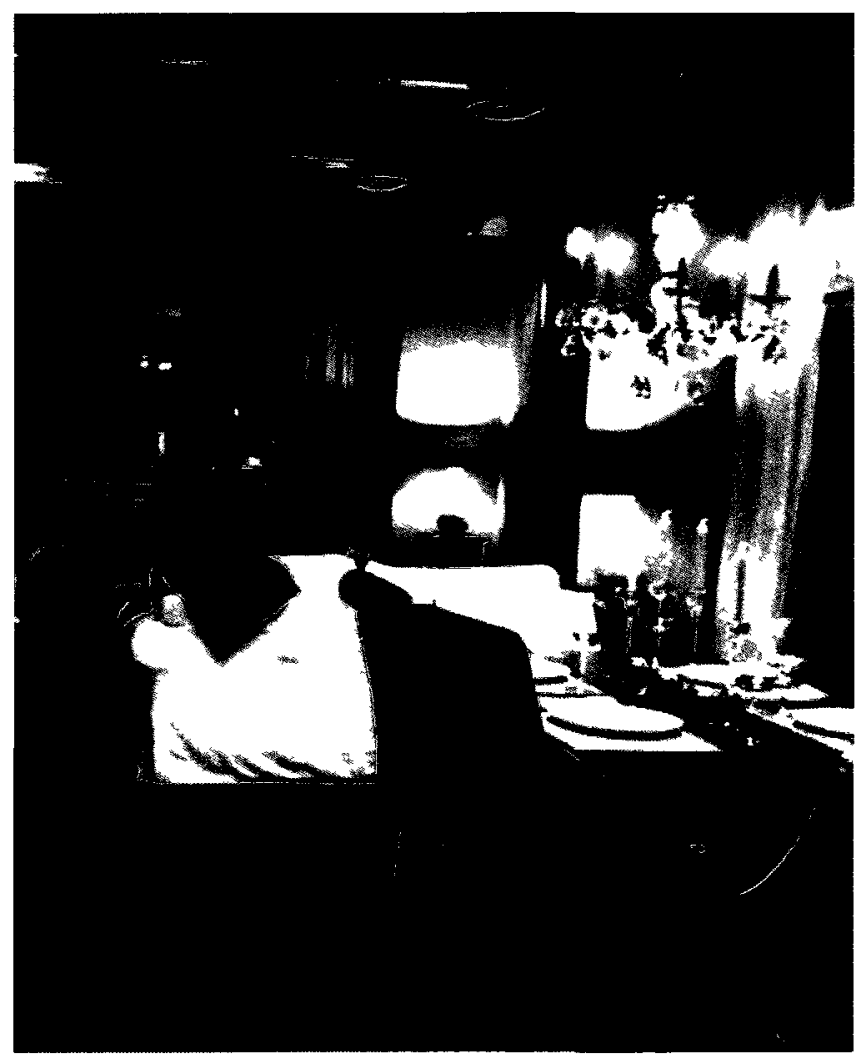

Illustration 13: Large dıning area 



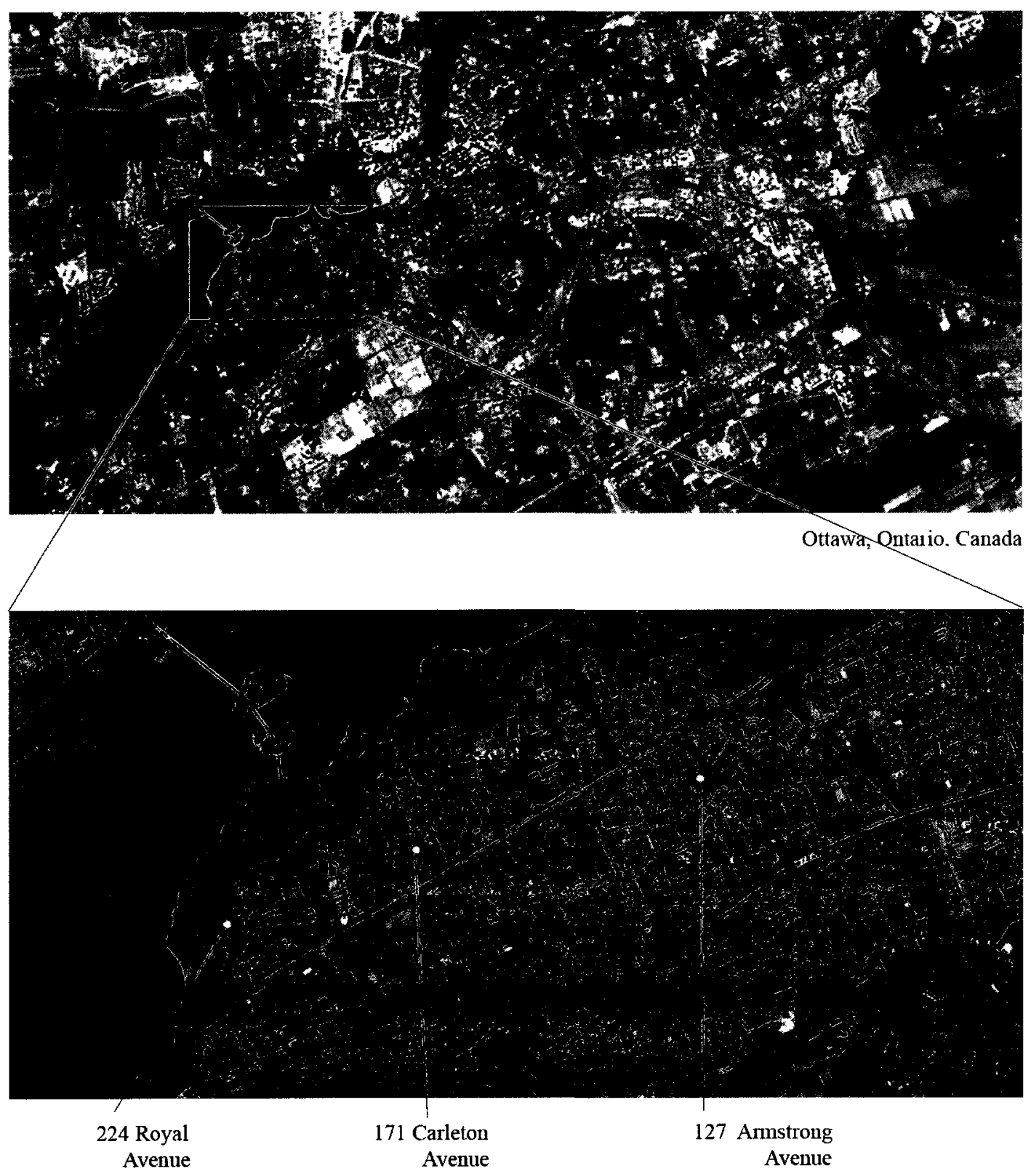

Illustration 15: Locations of Urban houses used in Analysis 


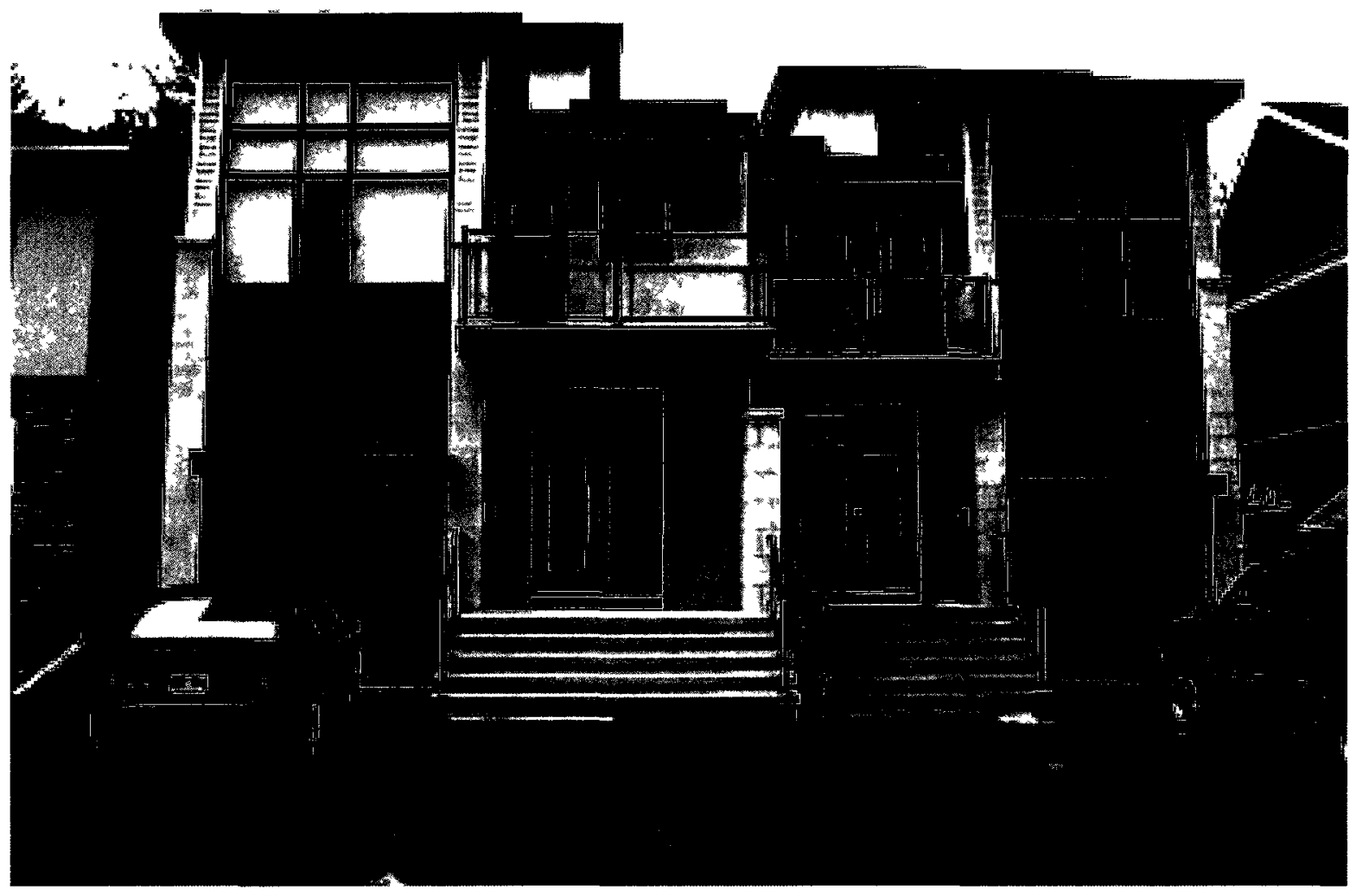

Illustratıon 16: 224 Royal by Hamel Desıgn 


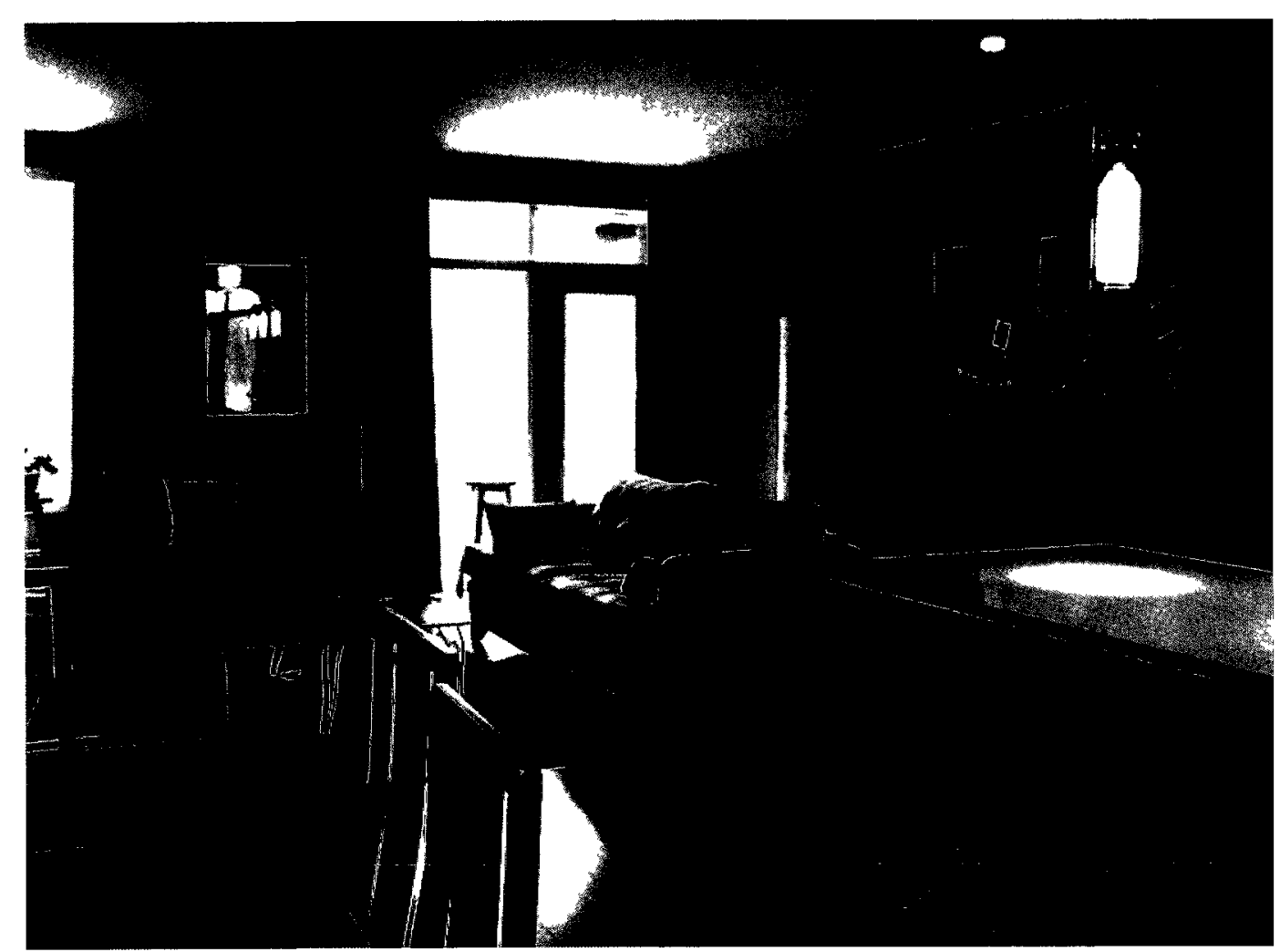

IIIustration 18. Niche on back wall behınd living area

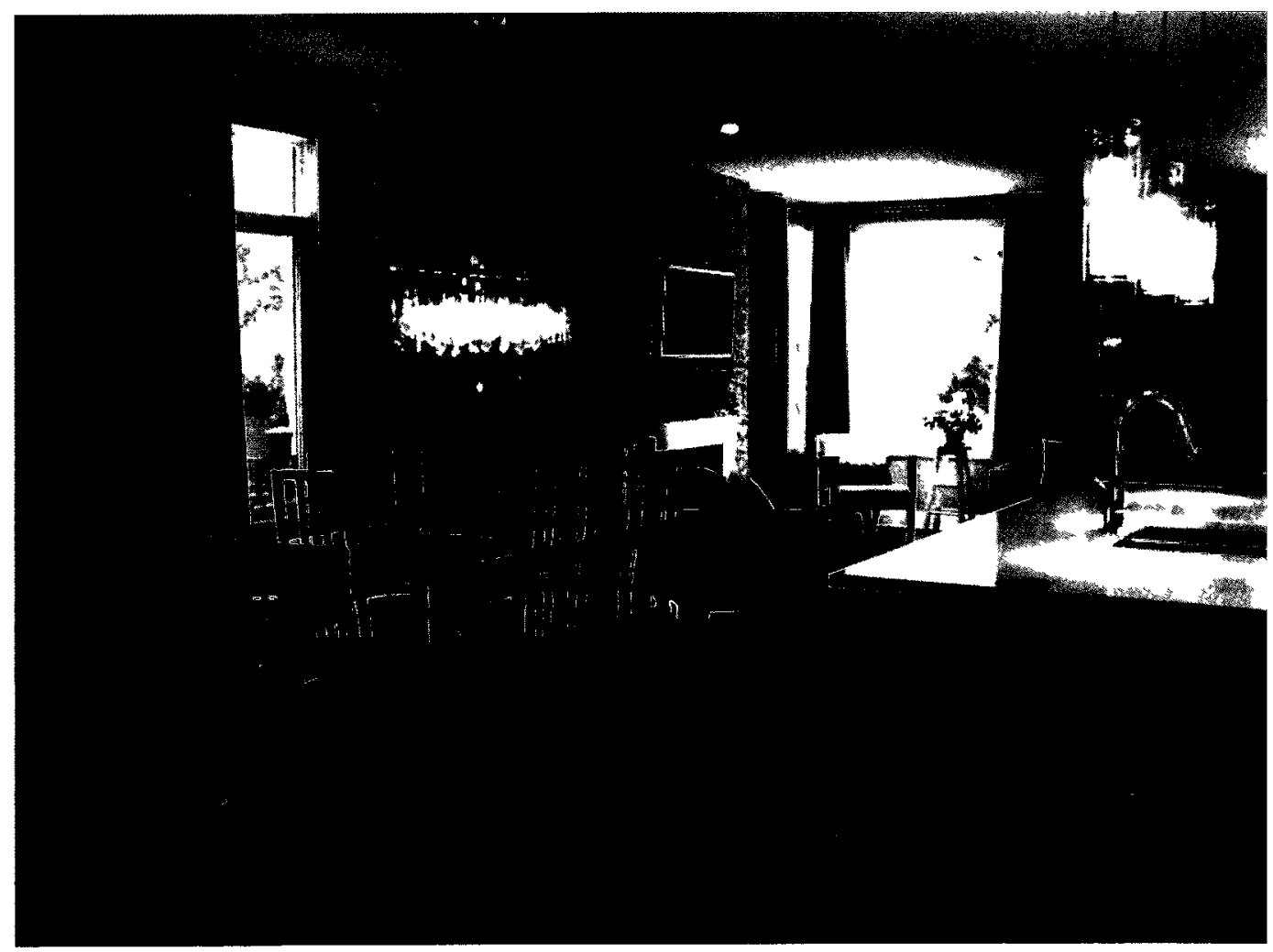

IIIustratıon 19: Stone wall in living area and dınıng area 


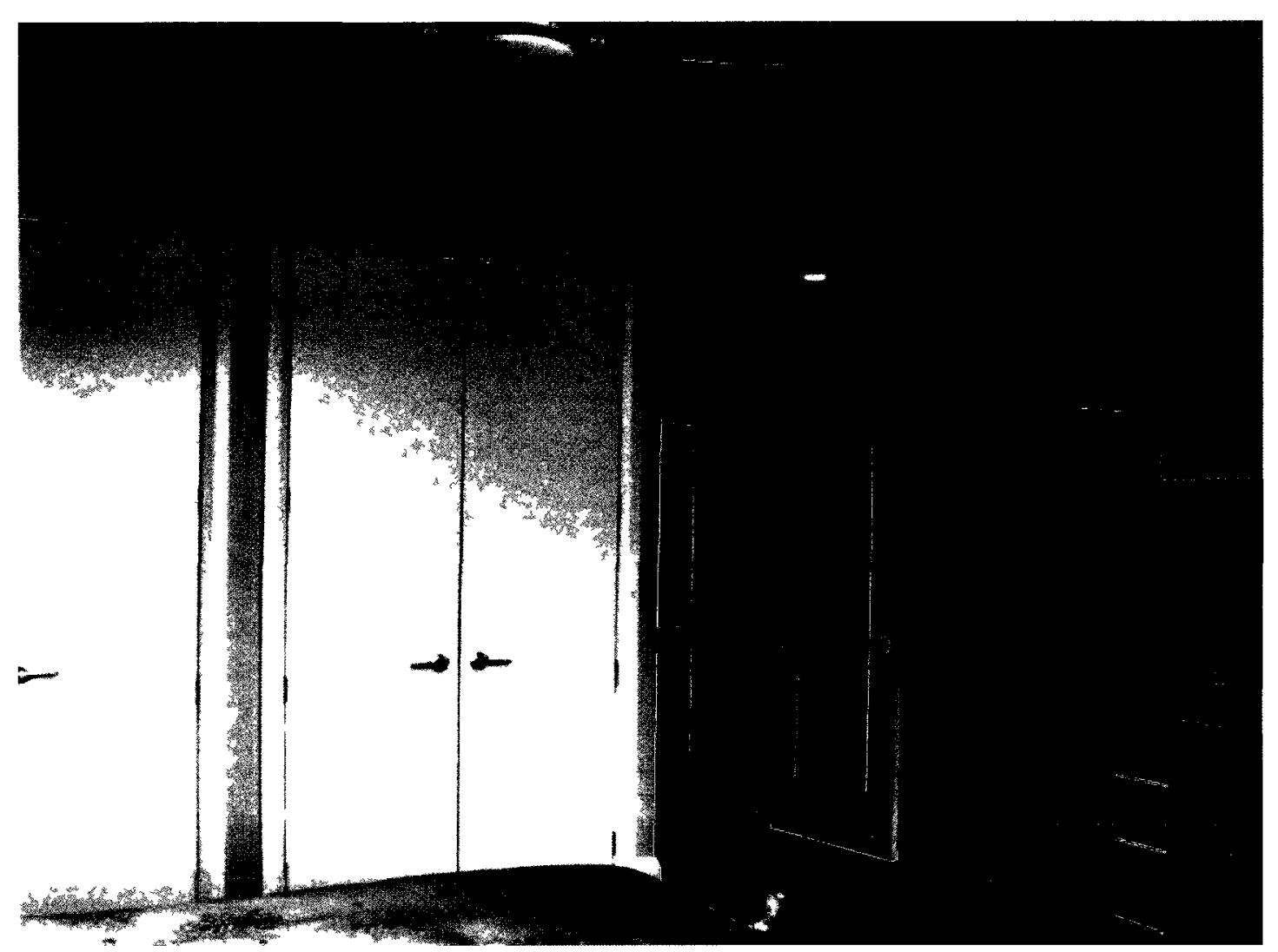

Illustration 20 Celling heights in master bedroom delıneate spaces, and create unique areas for storage or showcasing

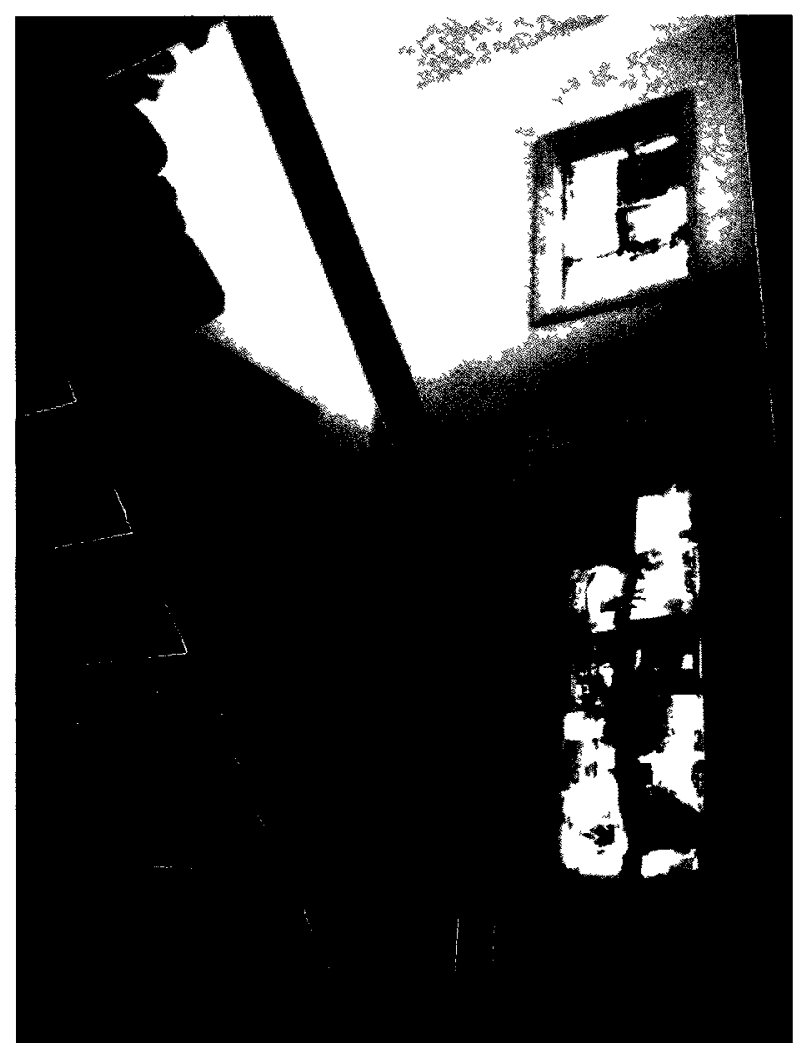

Illustration 21 Lots of light brought into stalrwells to bring light into the middle of the house 


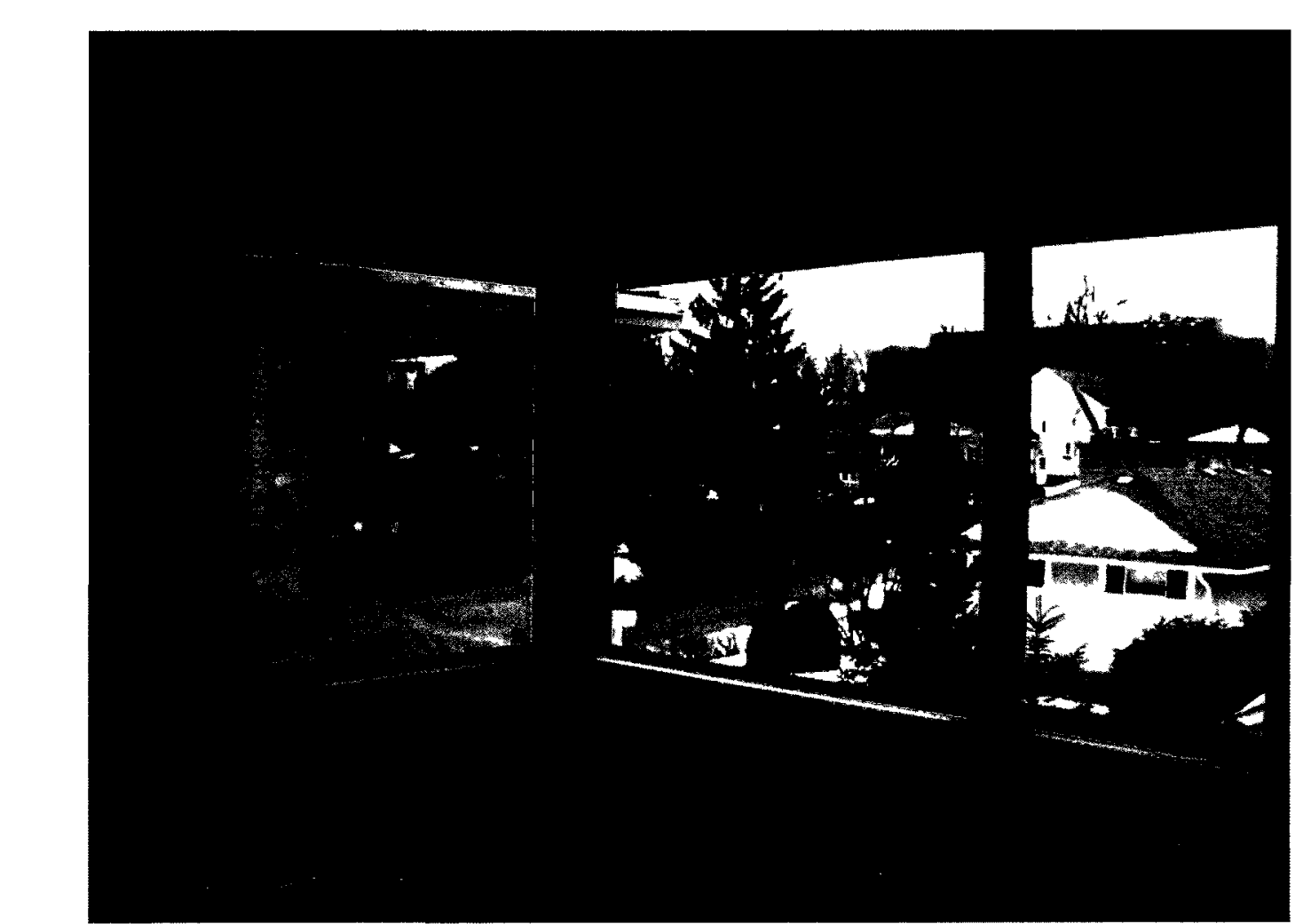

IIIustratıon 22. Corner windows help bring light in, as well as extend the interior out

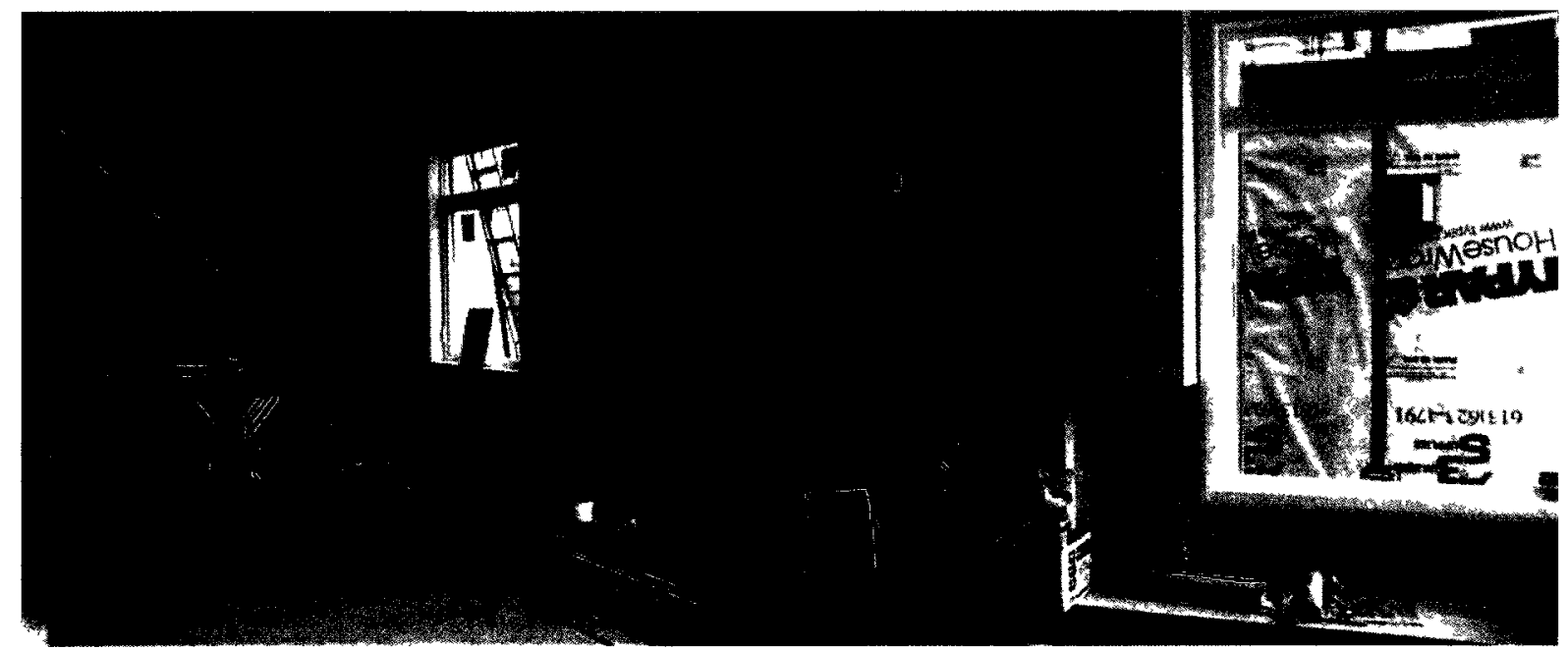

IIIustration 23. Fireplace adds a unique feel to the space, and increases the discourse between the architecture and inhabitant 


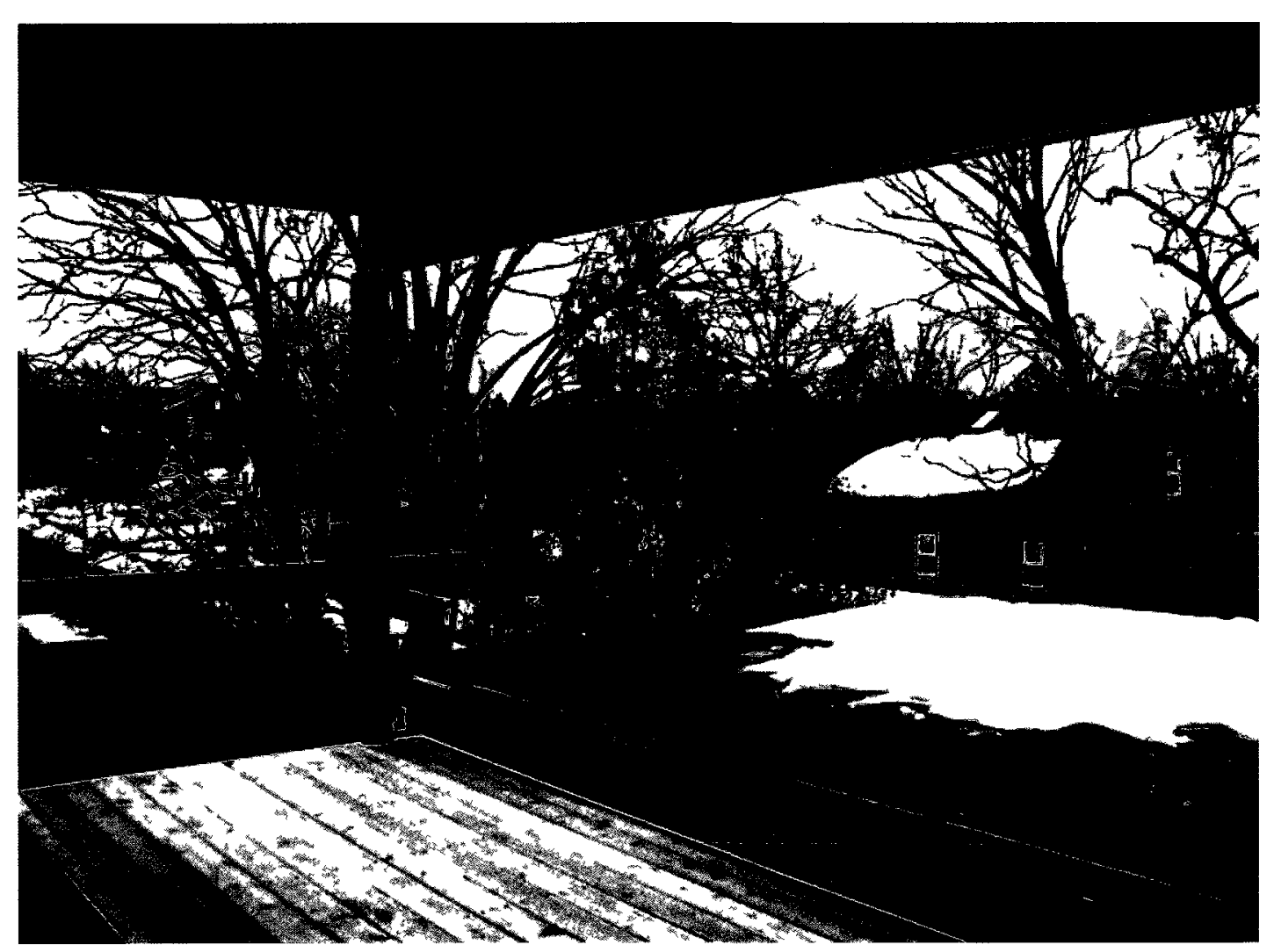

IIIustration 24 Roof terrace

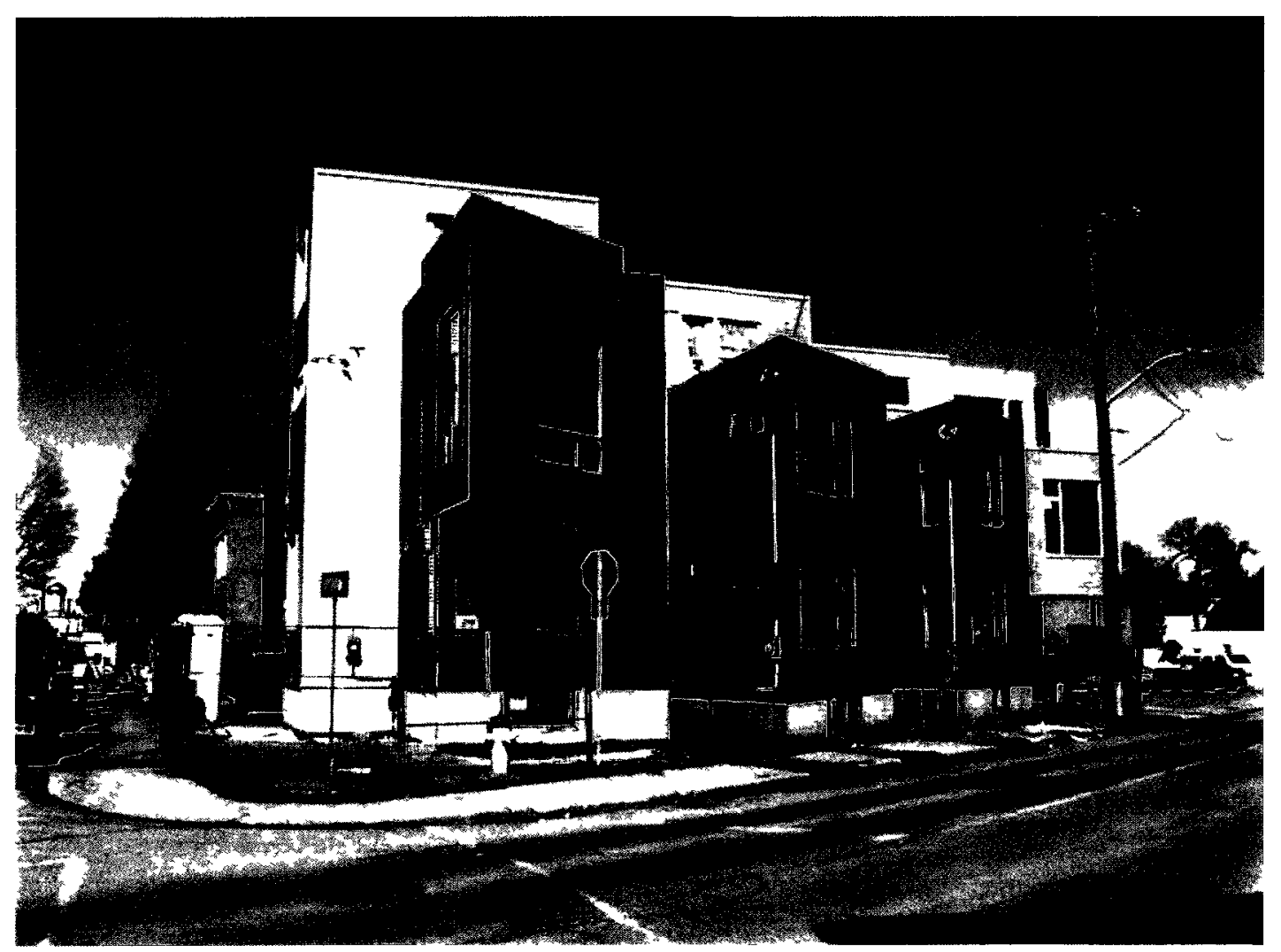

IIlustration 25127 Armstrong, by James A Colizza Architect 


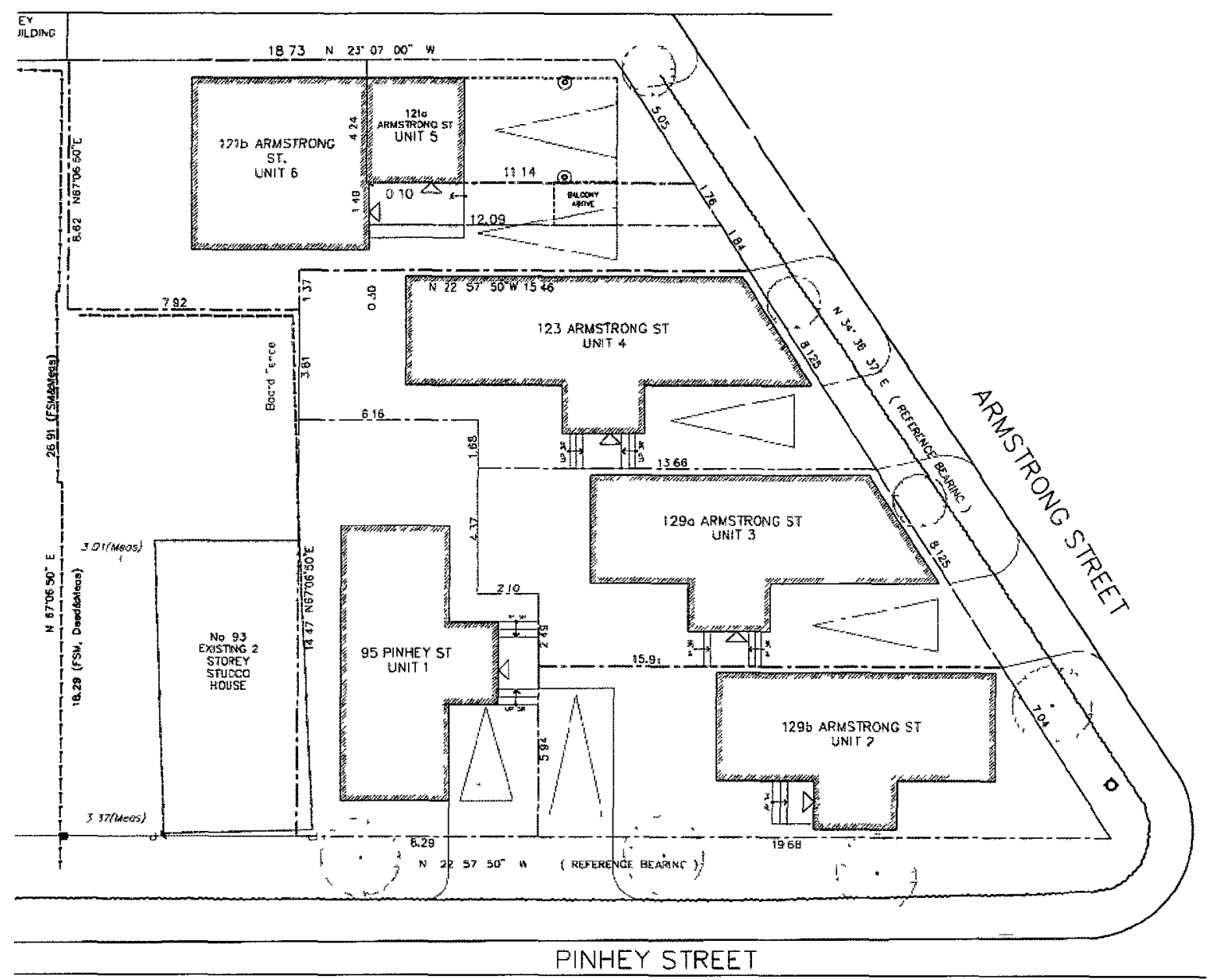

IIIustration 26: Site plan of the Armstrong development

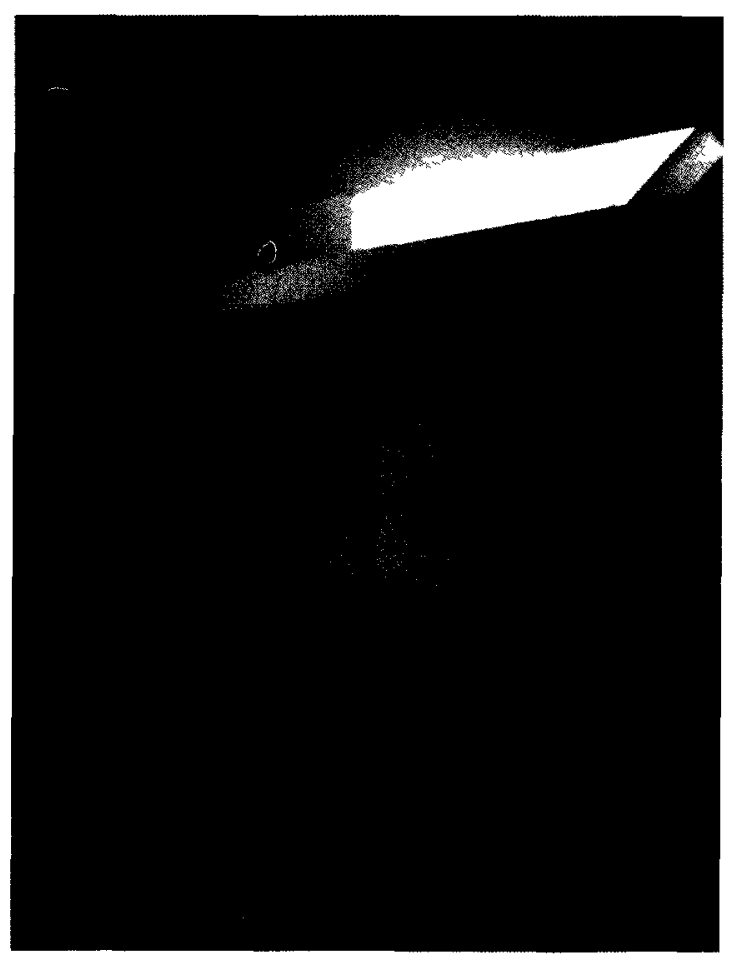

IIIustration 27: Open space above the closets, IIIustration 28: View from /Iving space into kitchen, create unique glimpses into other areas of the past stairwell 

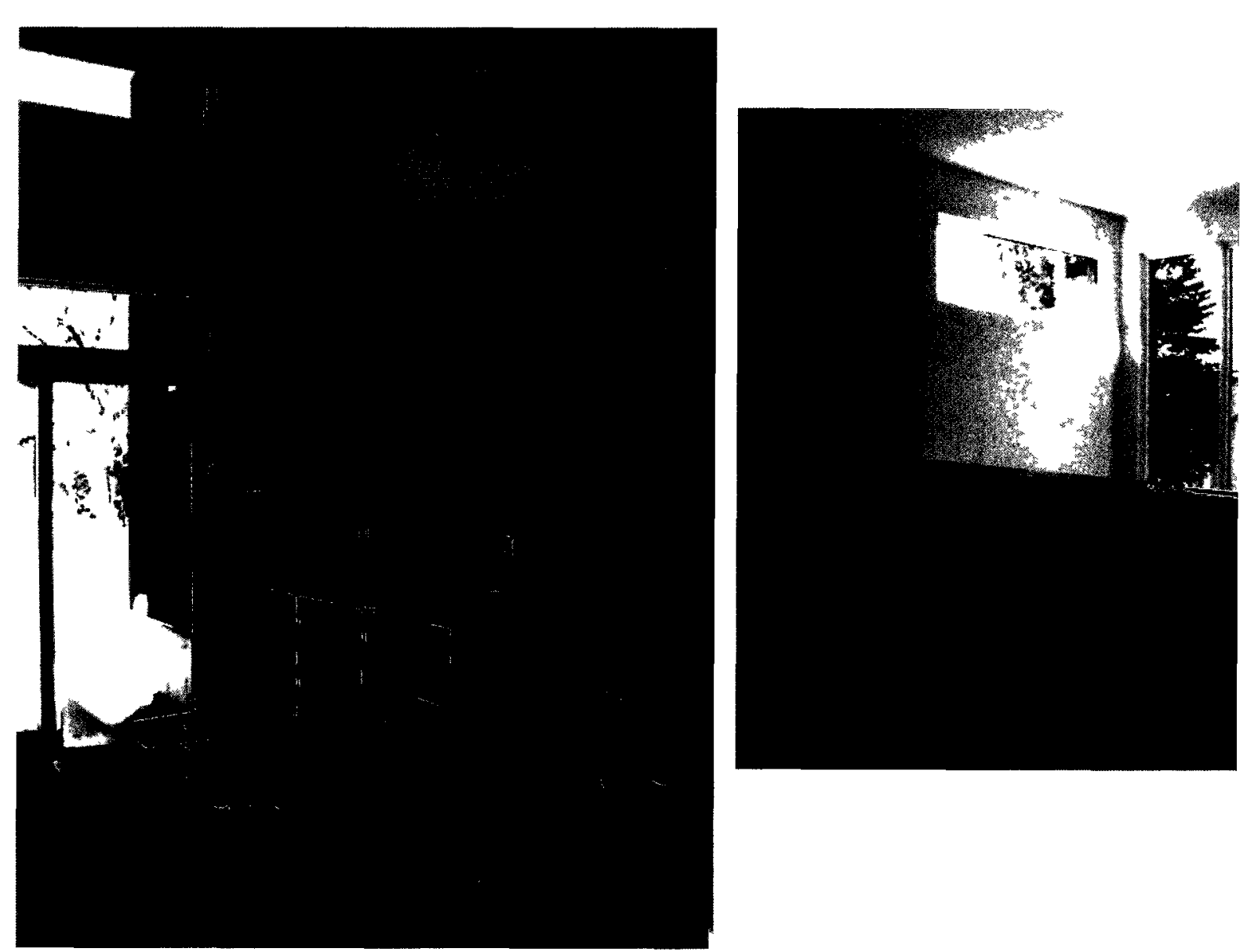

IIIustration 29 Kitchen with a double height portion, office (right) lookıng onto the double heıght

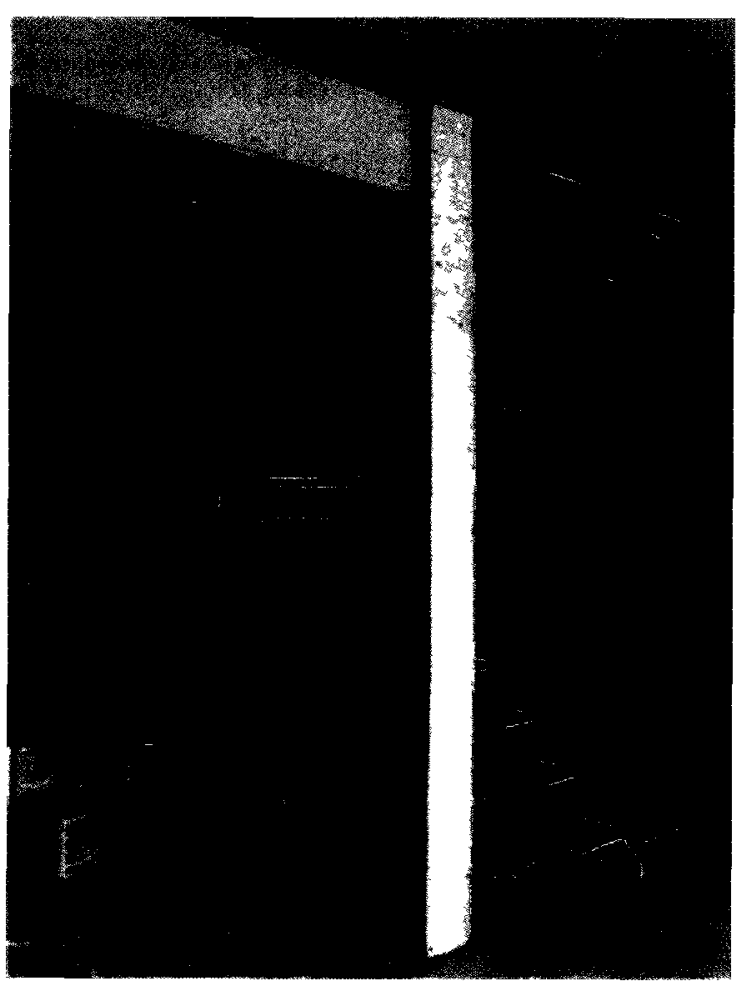

Illustration 30 Interior windows for views and glimpses into other areas of the house 


\section{Chapter 3 The Space Metaphor}

\section{Creating the Space-Metaphor}

The term metaphor typically relates to two words, one applying to the second word. On the topic of metaphor, Paul Ricoeur sees that "the feature of metaphor that we put above all other features - its nascent or emerging character - is related to the function of poetry as a creative imitation of reality"13. For example: The colour of a wool hat is snow white; we know that white, as a colour, could actually be slightly yellow, or beige, and there are even more subtle hues of white, but to describe white in in relation to snow, it takes on additional meaning other than just the colour of snow. The experience of looking at snow on a sunny winter day is so bright and sparkling, that it is hard to look at. Even though the hat does not have the same properties as snow, the words that describe snow are transferred to the hat, given it more meaning than just a plain white hat. Snow also carries the connotation of pureness, like after a snowfall, and the snow is untouched and pure. It is in this sense that the metaphor is a poetic reading of reality, a

13 Ricoeur, Paul. "Metaphor and the Main Problem of Hermeneutics." New Literary History 6.1, On Metaphor (1974) pg. 109 
thırd meanıng. Comıng back to the snow white hat, we have the meanıng of white (without pıgment) and the meanıng of snow (pure and blındıng). Combıned, they create a new meanıng - a hat which is bright and clean. This sımılar effect happens withın the confines of the house. The characteristics from materials, forms, lightıng, and arrangement withın the home project additional meanıngs into the space, creatıng a third meanıng of the space.

Space, as suggested by Susan Kent, editor of Domestic Architecture and the Use of Space, is static. In her essay entitled Activity Areas and Architecture: an Interdiscip/inary View of the Relationship between the Use of Space and Domestic BuIlt Environments she also adds that "architectural partitions usually are conscious manipulations by humans to create boundaries where they do not exist in nature"14. Not only are we creating boundaries withın our houses, it means we are makıng conscious decisions to form spaces as well. If space is in fact formed by boundaries, this presents the idea that it has a structure, which are the boundaries that create it. In contrast, noted physicist and philosopher of physics Max Jammer, does not see space as a result of creating boundaries. "The structure of space", as explained by Jammer is "not, in the last analysis, anything given in nature or independent of the human thought. It is a function of our conceptual scheme" ${ }^{m 5}$. Space, rather than having a structure as Kent suggests, is a perceptual construct of our minds. This theory corresponds with Bachelard, who views spaces as a place for day dreaming, a place that can take you elsewhere, and therefore a perceptual entity. These places are not always delıneated, or created by boundaries, but

14 Kent, Susan Domestic Architecture and the use of Space An Interdisciplınary Cross-Cultural Study Cambridge [England], New York Cambridge Universıty Press, 1990 Pg 2

15 Jammer, Max Concepts of Space, the History of Theories of Space in Physics 2nd ed Cambridge, Mass Harvard University Press, 1969 pg 173 
rather by the extent of our experiences and memories.

Following Jammer's theory, space can be understood as the relationship between the world and the imagination - our perception of reality. The perception of the spaces we inhabit form perceptual models in our minds. It is through these perceptual models that we are able to see, interpret, and remember the world. As a consequence of time and new experiences, the perceptual models begin to break down, and new perceptual models are made. Anthony Jackson describes this phenomenon in Space in Canadian Architecture:

our shifts in taste occur when new perceptual models are formed. Perception is at the same time cause and effect, both stemming from and itself inducing cultural conditioning. Its capacity for change lies in its composition. Being strands within a cluster of ideas and images, its components have their own evolutionary potential. New links can be made, new combinations can be formed. As the constituent parts of a mix begin to lose their mutual reinforcement, the apparent objectivity of the perception starts to fall apart. Not only do our judgements alter but so, apparently, does the very way we see ${ }^{16}$.

Since our perceptual models change over our lifetime, so does the way we perceive the spaces we occupy. This type of change in perception can be experienced when entering a room you have not entered for years. As one grows older, and has more life experiences, the way one views space becomes very different. To a child, everything is tall, and mysterious, but when the adult returns to the same space years later it seems small and less significant than it once was. Similarly, Bachelard notices the degradation of our perceptual models of space: "such dreams unsettle our daydreaming and we reach a point where we begin to doubt that we ever lived where we lived. Our past is 16 Jackson, Anthony.. Space in Canadian Architecture. [Halifax, N.S.] : Tech-Press, c1981. pg. 3 
situated elsewhere, and both time and place are impregnated with a sense of unreality" ${ }^{\prime 17}$. It is common that as your life progresses a space will begin to lose detail, and as a consequence you can begin to think it was only a dream. It is the extraordinarily vibrant and powerful perceptual models that will stay with us in our memory, while less powerful perceptual models will begin to break down, and ultimately become dreamlike.

So what does it actually mean to be a space-metaphor? As stated above, the spaces that we experience are perceptual spaces. This means that at the time you enter a space, all of the characters surrounding it can manipulate and change the overall experience of the space. Consequently, the perceptual models formed in your mind are space metaphors, meaning that, as you experience other spaces, the perceptual models that you have already created are recalled and contrasted with the new spaces. This new contrast can result in new combinations, or the taking away of part of the memory and replacing it with a different part of the new memory. If the original perceptual model was powerful and strong, you create a new model or memory in your mind, rather than adding or subtracting from the original. If the models are not strong, then your memories are manipulated, and assembled together and a fabricated memory is created. Therefore, space is never really perceived by its boundaries, but rather perceived through the extension of the imagination, experiences, and personal memories.

It is in this state of constantly changing perceptual models that the spaces around us begin to take on new meanings. As we experience a space, perceptual models are triggered, adding its meaning to the space we currently are inhabiting, consequently, adding another meaning to the new memory. Bachelard describes the metaphor in a

17 Bachelard, pg. 57 
sımılar way as Ricoeur, callıng it "a fabricated ımage," but "without deep, true, genuıne roots" ${ }^{\prime 18}$. Though space is a fabricated perception, it is also an interpretation that is built upon multıple realities from past experiences. Therefore, space is not without genuine roots, lıke Bachelard suggests, fabricated with multıple realıtıes that come from our experiences.

Though memories can be formed by any activity, or space, they must be strong to be recalled. For a memory to be recalled, somethıng withın the memory, a hook, somethıng unıque, needs to be present. When that hook is seen again, or is given reference to, it becomes the trigger for that memory allowing you to re-experience it. Its meaning is then transferred to the space it is remembered in, causing one to perceive it differently than they might have. In essence, the space metaphor, is a perception, and is fabricated from an amalgamation of ımagınation, realıty and our memory. It is through the process of creatıng these space metaphors that the life in a house is found. The house lives through your perception of it. While strong memories are formed through strong character features in the house, such as, materialıty, lıghtıng, form, and arrangement, memories are also triggered by these characteristics

\section{Space Metaphor Triggers}

In order to be able to create space metaphors, there must be triggers. As we wander through a house, its appearance, its nooks and crannies, its smell and, the quality of light, all provide triggers that can bring new or familiar meanıng to the space. It is the quality of the architecture that can create a metaphor. Wright describes a situation where

18 Bachelard, pg 74 
colours trigger memories:

mere accidental coloured chalk-marks on the sunlit sidewalk, perhaps, will make me pause and 'something' in me hark back to 'something' half remembered, half felt, as though an unseen door had opened and distant music had - for an instant, come trembling through my senses ${ }^{19}$

Just as Wright talks about coloured chalk as a trigger for memories or feelings that were once experienced, so too can the characteristics of a house become a trigger for our own memories.

Wright also claims that "it is the quality of depth that alone can give life or purpose to the other two dimensions and result in that integrity in architecture"20. For a house to have integrity, it must have a life, and, as we have already concluded, character is able to create space metaphors that bring life into a house. How then, does depth come into the equation? Depth, on its own, has many meanings: it can refer to a spatial dimension; complexity or obscurity; the amount of knowledge; intelligence; wisdom; insight; feeling in something; or simply a component of the the three dimensions. In each case, all of these definitions can relate or describe character, the unique features that are found in a house. While depth and character share some similar aspects, the quality of depth, and quality of character are not synonymous. The quality of depth, rather than meaning superiority, can be defined as the intensity, or visibility of the character within a house. It is possible that a house could have a couple of unique characteristics, but, if they are not intense enough, or visible enough they cannot trigger a space metaphor, and therefore create the life within a house. Therefore, all the components of depth must

\footnotetext{
19 Wright, pg. 269
}

20 Wright, pg. 318 
play a role in creating the character of a house, and they must work together to create an integrity that can form space metaphors to bring out its life. In the following section, we examine how these specific components such as, materiality, lighting, form, and arrangement, are able to form character within a house.

\section{Materiality}

The materiality within a house is an integral part of creating the space metaphor. Not only can specific materials become triggers themselves, but they can also create different atmospheres which also create space metaphors. Materials such as stone, wood, terra cotta, glass, and even steel, all have their own characteristics, and each defining character contributes to the whole character in a house. Bachelard turns to Henri Bosco's Malicroix and his description of his house called La Redousse ${ }^{21}$, where he states,

There is nothing like silence to suggest a sense of unlimited space. Sounds lend colour to space, and confer a sort of sound body upon it. But absence of sound leaves it quite pure and, in the silence, we are seized with the sensation of something vast and deep and boundless. ${ }^{22}$

The materiality of a house not only creates atmosphere and triggers memories with its visual appearance, but the properties of the material affect the sound of the room, and even the smell as Bachelard also recalls his own room:

I alone, in my memories of another century, can open the deep cupboard that still retains for me alone that unique odor, the odor of raisins drying on a wicker tray. The odor of raisins! It is an odor that is beyond description, one that it takes a lot of imagination to smell. ${ }^{23}$

\footnotetext{
21 Bachelard's footnote for the translation "Corruption of redoute: retreat"

22 Bachelard, pg. 43

23 Bachelard, pg. 13
} 
The materiality is so much more than just an element that is used to cover up the structure of the house. The use of materials can enliven and deliver us to our past, and to our deepest thoughts.

Wright also wrote about materiality in a house and consistently made sure that in his house designs the materiality was well thought out, and executed in a deliberate way. In reference to stone, Wright states that "the character of the wall will be determined also by the kind of stone, by the kind of mason, the kind of architect... but most of all, by the nature of the stone itself ${ }^{\prime 24}$. So it is not only the stone itself that will begin to create space metaphors, but also the treatment of the stone, who crafts it, how it is installed, and how it is used. Taliesin West, and Falling Water are two great examples of Wright's work which highlight the use of stone in separate ways.

Taliesin West, for example, uses the stones from the desert area, but rather than using them as a structural entity, he uses them for their materiality (III. 31). Desert stones are wired into concrete forms, and with concrete poured around them create a structural entity. The stones become part of the landscape of the walls, haphazardly strewn in the concrete like they would be across the desert. Also, by using the stone wall up to window heights and not cutting into them for windows, the stone portrays a feeling of being in a desert cave, providing a cool oasis for life to continue in the hot desert (III. 32). The colours of the stone are warm oranges, reds, greys and black, keeping the space bright. From the materiality alone, it induces a metaphor that provide us with the image of a cave, the desert, and warmth. And though each of these work separately, they also work together to form an entity.

24 Wright, pg. 272 
On the other hand, Falling Water, gives a different perspective on the use of stone. The stone on the floor is waxed so that when light shines off of it, it looks like there is a thin layer of water on it (III. 33), giving it a cooler feeling than the warm, dry desert stone at Taliesin West. The walls are also built from similar stone as the floor, which gives the feeling that the walls are rising out of the floor, like a rock wall that forms a waterfall, and you are in a cave behind it, safe and dry, looking out through the windows. Especially around the fireplace, stones, or seemingly rocks at this point, actually come up out of the floor, and become a part of the wall (III. 34). This strongly enforces the feeling that the floor is covered in a thin layer of water. Even the ripples of the stone itself, gives the illusion of sparkling water (III. $33 \&$ III. 34). The overall atmosphere is cool, but at the same time cozy and sheltered like a cave behind a big waterfall. Similarly, Taliesin West and Falling Water both give the atmosphere of a caves but in two very different ways. In this instance, it is easy to see how the choice of materiality can be crucial to convey the ideas and atmospheres you desire.

Form

Unlike the other triggers, form cannot be a trigger on its own. Form can be considered the amount of a material and its shape in a single area. EM $2 \mathrm{~N}$ architects suggest that using form you can "give the small volume strength, [and] create a strong shape that makes [an] identity" ${ }^{\prime 25}$. Creating strong forms is crucial in small homes, because you need the impact to make a space feel big, but a strong form that creates an identity is an essential part in formulating a character. A form can relate to a structural element, or can emphasize something that is important to the inhabitant. Form also provides the

25 Komanoya, Rico. Mini House Style. New York, NY: Harper Design, an imprint of Harper Collins Publishers, 2004. pg. 21 (EM2N Architects) 
much needed 'nooks and corners' that Bachelard talks about. "Every corner in a house, every angle in a room, every inch of secluded space in which we like to hide, or withdraw into ourselves, is a symbol of solitude for the imagination, that is to say, it is the germ of a room, or of a house"26. The form of the materialıty, or the shapes that create identities indulge in our need of these secluded spaces. These spaces are playful and contemplative. They create spaces that can become a niche for activities, or a focal point of the house.

Using this concept of form, Huttunen and Lipastı Architects were able to design a small house that had strong visual impacts Inside and out, called Villa Linnanmakı (III. 35) This villa uses the large domınant windows to create views that extend the interior to the exterior. As well, the large form on the second floor expresses an identity which can be distinguished within the landscape of the trees. This form is reminiscent of a tree fort high up in a tree, and the large panes of glass reinforce this Image (III. 36). If the WIndows had been small, and porthole like, they could instead create an opposite effect, of being deep under the sea, in a submarıne. Just the slight change in size can change the perception and character of this house. The form of the upper floor, as well, clearly delıneates it from the rest of the house makıng it a special place, somethıng out of the ordınary. In their description of the villa, Huttunen and Lıpastı Architects describe this as a room that can allow for children to play in, and adults to visit where the ceiling is high, but as the roof is sloped, one end of the form is only 3 feet high, and is perfect as a sleepıng area for children. It is in this way that the form plays a crucial part of the use of the space. The head height determınes who is allowed in certain areas, and creates special intımate corners for chıldren to use.

26 Bachelard,pg 136 


\section{Arrangement}

The arrangement of rooms, as well as the arrangement of the windows are essential when creating character in a house, and especially in a small house. Sarah Susanka, writer of The Not So Big House, and Creating the Not So Big House, finds that "aligning view and features" can "[give] the whole house an integrity that's palpable"27 as well as "[offering] unobstructed sight lines to whatever space is diagonally opposite the kitchen, dining, and living areas, the house will seem bigger and more welcoming" ${ }^{28}$. Arrangement not only provokes thoughts of other rooms in a house, or visually and socially connects them, but also plays with the arrangement of the rooms in our minds. As one thing connects to another, spaces begin to meld together turning into new spaces, or alluding to other spaces which seemingly could have been connected but were actually a different part of another house. Bachelard describes this situation as a "strange situation. The space we love is unwilling to remain permanently enclosed. It deploys and appears to move elsewhere without difficulty; into other times, and on different planes of dream and memory." ${ }^{29}$ In rooms that are clearly delineated with one or two entrances or exits, the rooms beyond turn into anything and everything from your life. Sometimes it is a classroom on the other side, sometimes the backyard, and even sometimes a room from a completely different house. The house transforms and shifts in your mind, slipping from place to place, and forming new perceptual models.

27 Susanka, Sarah. Creating the Not so Big House : Insights and Ideas for the New American Home. Newtown, CT: Taunton Press, 2000. Pg. 37

28 Susanka, Sarah, and Kira Obolensky. The Not so Big House : A Blueprint for the Way we really Live. Newtown, CT : [Emeryville, CA]: Taunton Press ; Distributed by Publishers Group West, 1998. Pg. 77 29 Bachelard, pg. 53 
Home in the Woods, designed by Jacobson Siverstein Winslow Architects in Inverness, Calıfornia is a perfect example of a small house that is designed to allude to space with the arrangement of the rooms, as well as form interesting connections and delıneation of room strategies (III. 37). This house was built for a single woman, who needed a space for entertainıng guests, and also wanted the potentıal for an office. At 1,150 sq. ft., this house is petite, but with the use of diagonal view, and alıgning features, it seems larger than it actually is. Simple features such as lowered beams around the dinıng area (which is just $7 \mathrm{ft}$. wide) delineate the space from the rest while keepıng it open (ill. 38). Not only do long lınes withın a house create a larger sense of space, but spacemetaphors begın to form from the unıque features which help delıneate each space. Niches and corners form around the open concept living and dınıng room, and as well walls and parts of the ceilıng become extra storage, and showcase her collection of dıshes, addıng a unıque touch to the space (III. 39) These niches become the 'restingplace for daydreamıng' as Bachelard describes.

Another house that capitalizes on the potential for room arrangement in a different way Is the Waddell House in Scotland. Buılt by Roderick Kemsley and Christopher Platt (Studio KAP), this is an addition which adds extra living area, kitchen, and study, to a pre-exıstıng house (III. 40, III. 41). The unıque relationshıp of the arrangement of rooms happens between the study, living area, and existıng house. As demonstrated in the photographs, from the informal living area you can catch glımpses into both the new study, which is also separated by an exterior terrace, and back into the existing buildıng (III. 42). The quick snıppet of views that one receives as they walk through these spaces allows hım to explore the house with his ımagination first, wonderıng where the spaces go, and what they look lıke, and what treasures are hidden behınd the walls, before they 
are able to physically explore the rooms.

\section{Lighting}

Though not a physıcal thıng on its own, lightıng plays an integral part in dictatıng the mood and atmosphere in a house, which in turn forms space metaphors. Even if one only experiences the effects of lightıng once in a room, or recalls movies, or even tales about that specific atmosphere, it is applied to other rooms that are simılar. Bachelard describes a situation where the cellar is always a frightenıng place: "In our civilization, which has the same light everywhere, and puts electricity in its cellars, we no longer go to the cellar carrying a candle But the unconscious cannot be civilized. It takes a candle when it goes to the cellar." ${ }^{30}$ Whether or not the candle is present when you enter a place that is notorious for being mysterious and ominous, the shadows still lurk in the corners makıng one's mınd race. Though when usıng natural light, a lot depends on the form of the windows which are to let the light in, and their placement within the house. A hıgh, long, thın window will let in a diffused light that washes over the room, and even on sunny days, the sun will not be shining directly into the room. The room can feel peaceful with this type of light as the light will never be intense. Simılarly, a larger window lets in a full amount of light and, intensifies the room. In the cellar, windows tend to be smaller and create sımılar effects, especially on a moon lit nıght. The attention to lightıng can define a room sometımes more than the partitıons or furniture In the room.

This concept can be seen in a vacation house in Maıne by Robert Knıght. Soft light from skylights are used in the study and upstairs hallway (III. 43), whereas on the main floor,

30 Bachelard, pg 19 
more conventional windows create intense lightıng in the lively areas of the house: the kıtchen and eatıng area (III. 44). The atmosphere between these two rooms is distınctly different, and begins to direct the types of activities that are performed in both. The atmosphere created in each of these areas also dırects the type of daydreaming that can happen. A softer space may invoke more contemplative thought, while a brighter space could lead to more adventurous daydreams.

Lightıng can also be used as a delıneation tool, especially in a multı-purpose space. Usıng lıghtıng, Sarah Susanka and James Larson, desıgned a house which, whıle it is open concept, uses lıght to distınguish different areas (III, 45, III 46). When everyone Is at the table, and the lights are only there, the rest of the house fades into the background and the 'eatıng area' then becomes a dınıng room. It creates a feelıng of separateness from the rest of the house. In reverse, when the 'living area' is in use, it is lit up and the dinıng area fades into the background, creating the feelıng that it is separate.

As it is clearly seen in the previous examples, the quality of depth can add a lot of character to a house. In most cases, it is a mixture of the four components together that create a strong character. Through the intensity of these components of depth, a character in a house materializes. It is this character that creates situations in the house where the memories from another space will apply to another formıng a spacemetaphor. It is through the space metaphors that the inhabitant is able to interact with their house and the life of the house is created. 


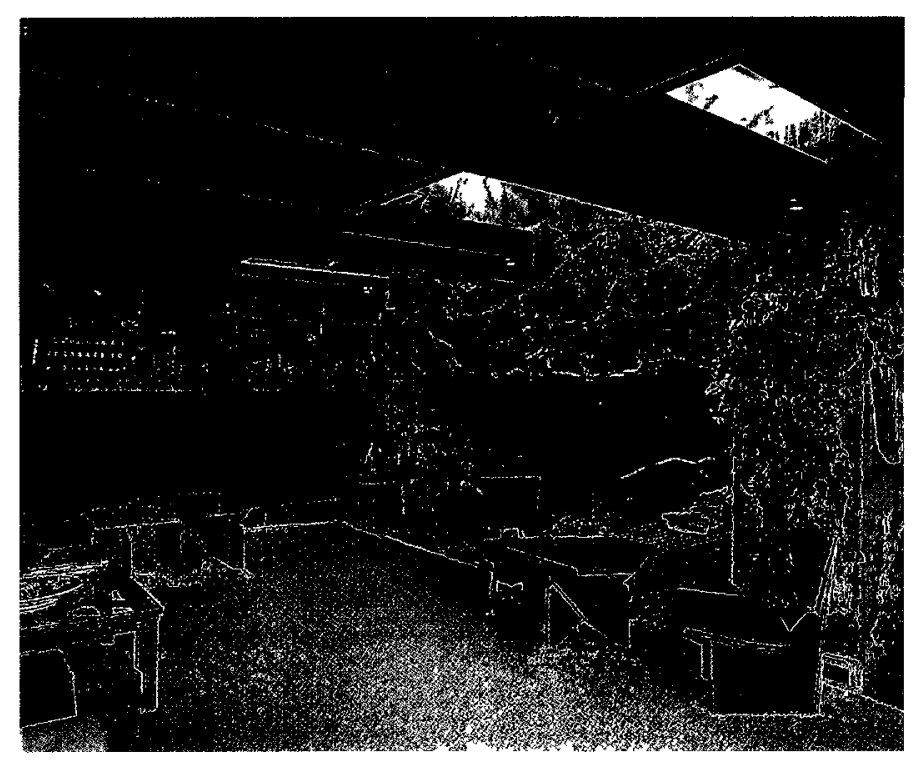

Illustration 31 Interior stone wall at Talıesın West

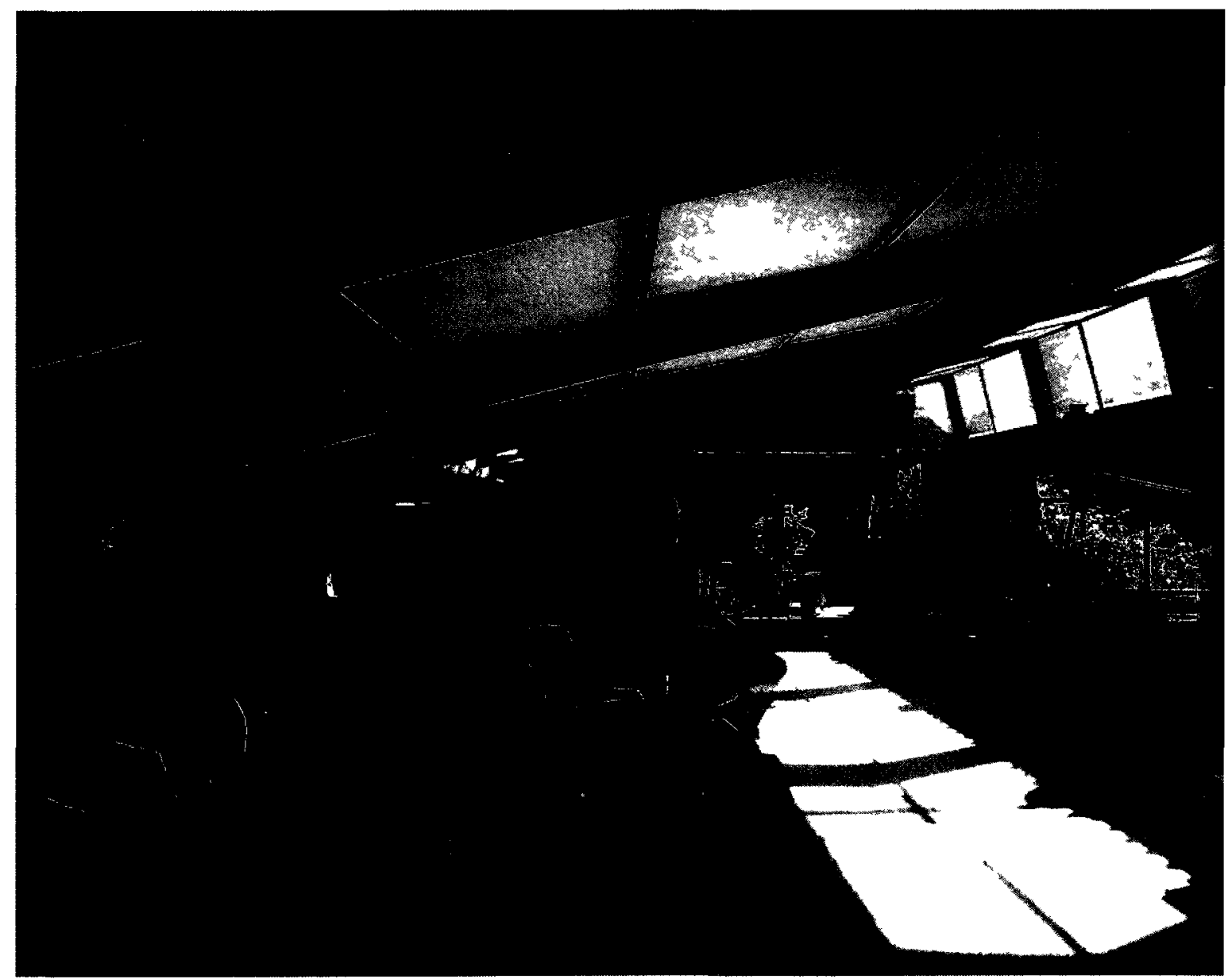

Illustration 32 LIving room at Talıesin West 


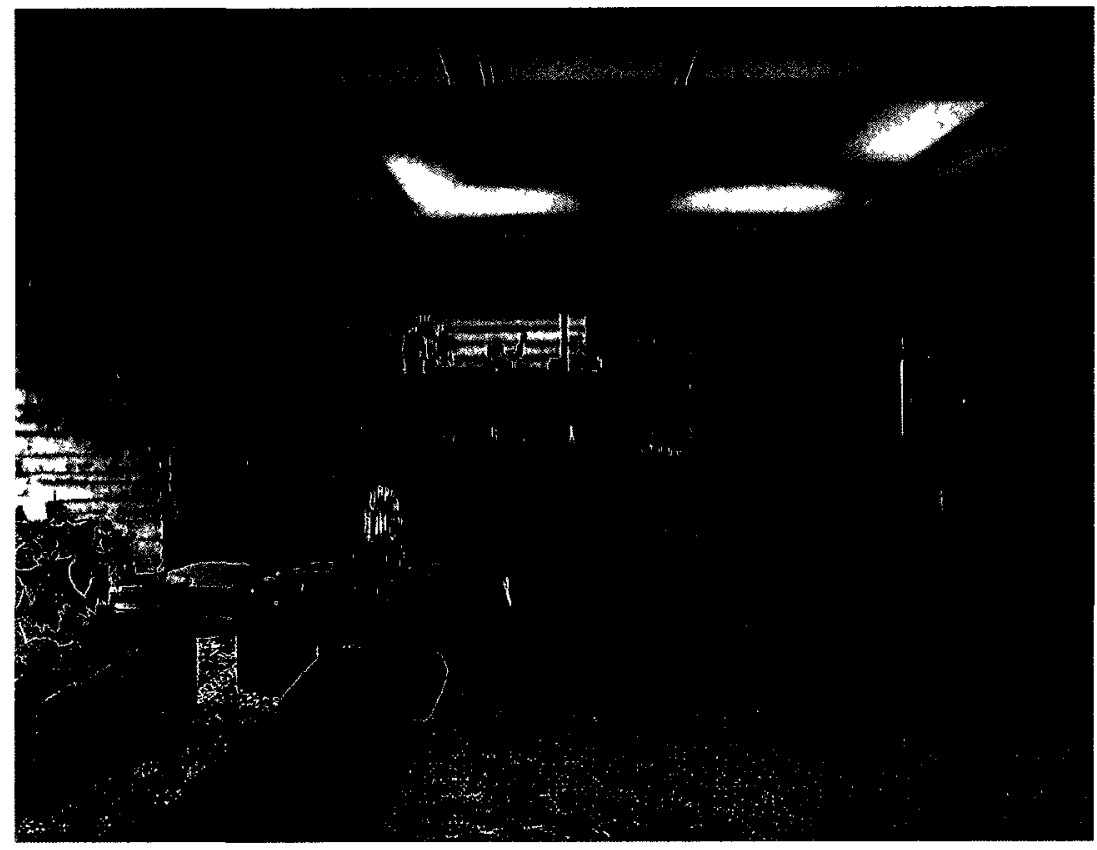

IIIustration 33: Falling Water

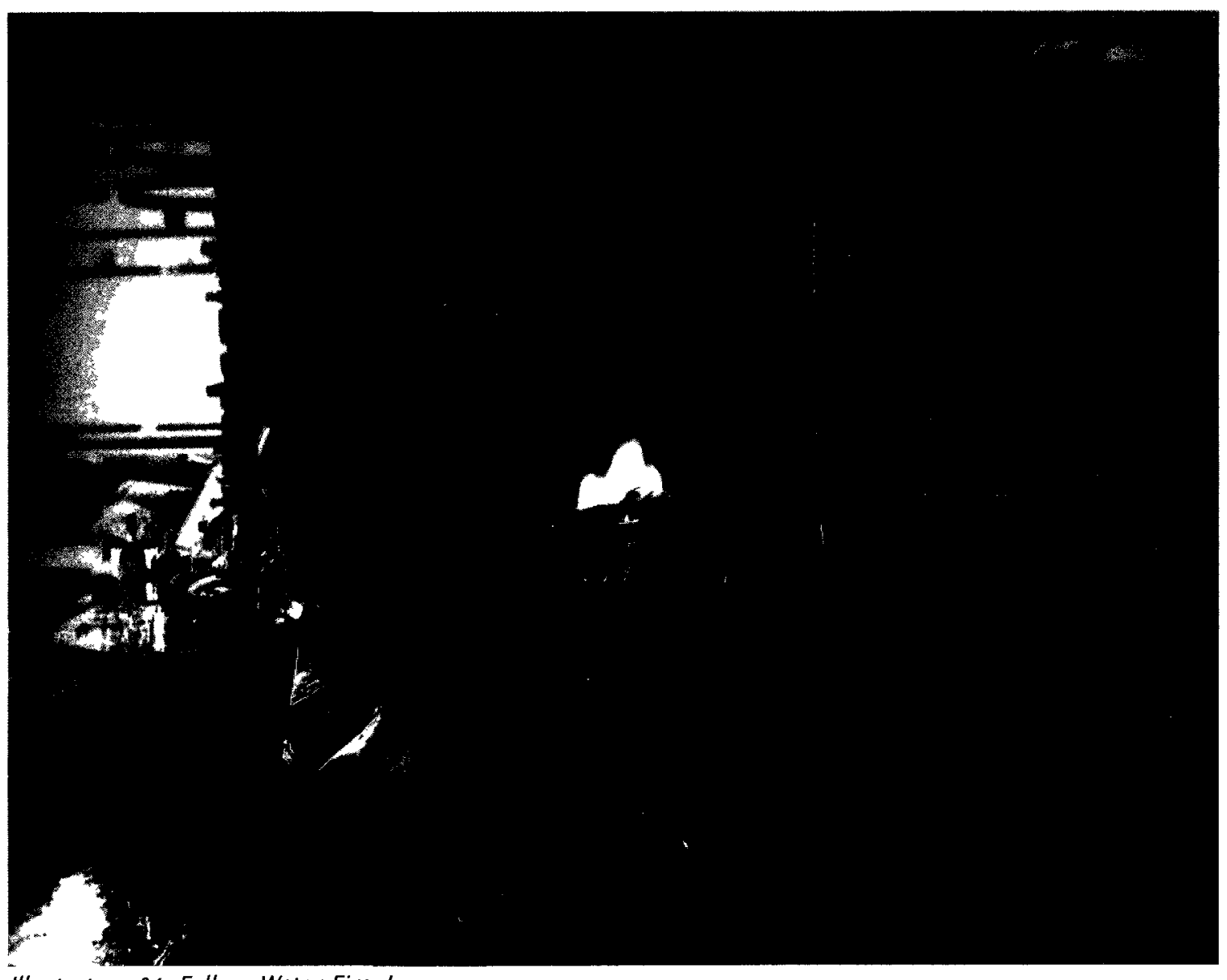

IIIustration 34: Falling Water Fireplace 


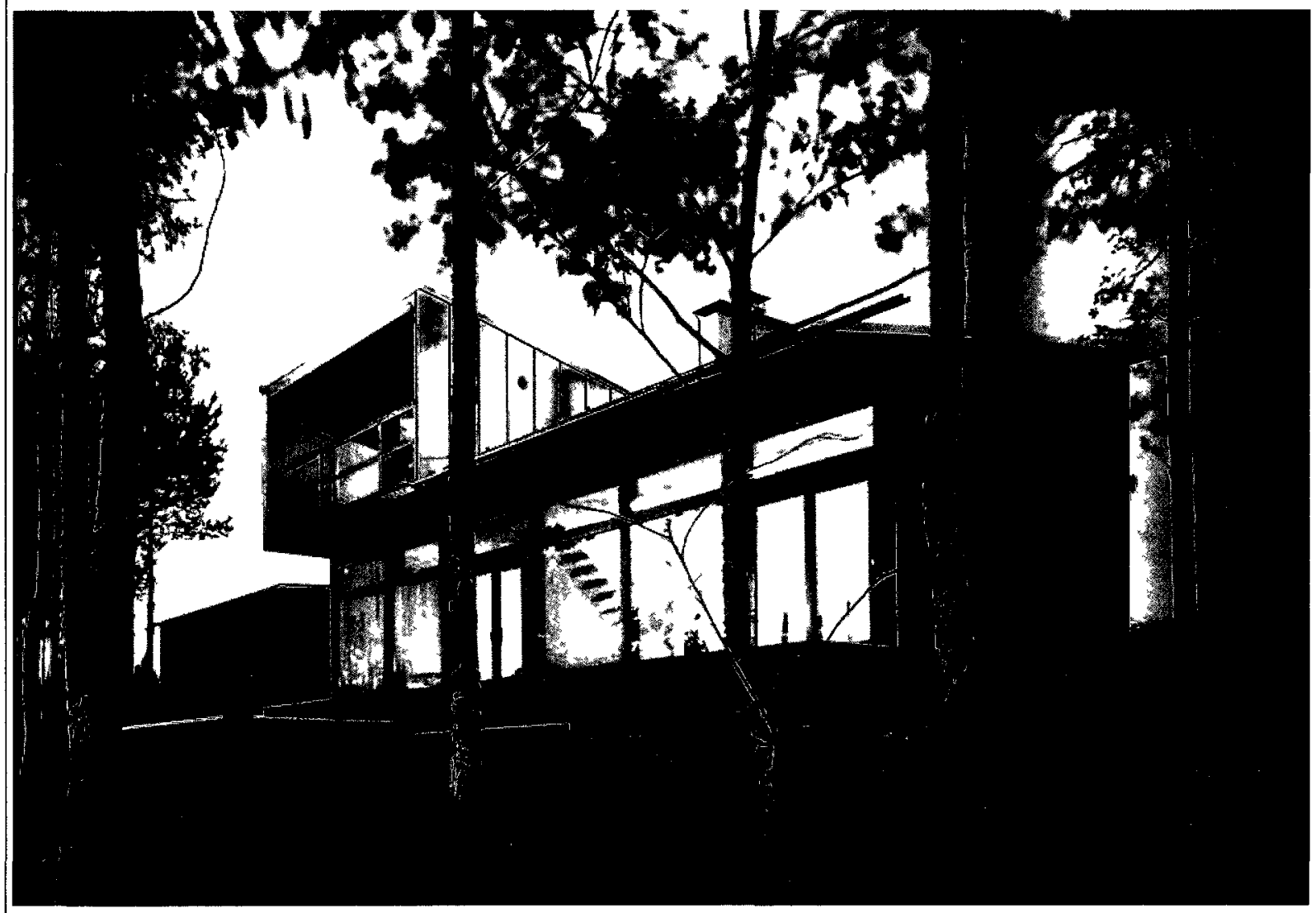

IIlustratıon 35 Villa Lınnanmakı

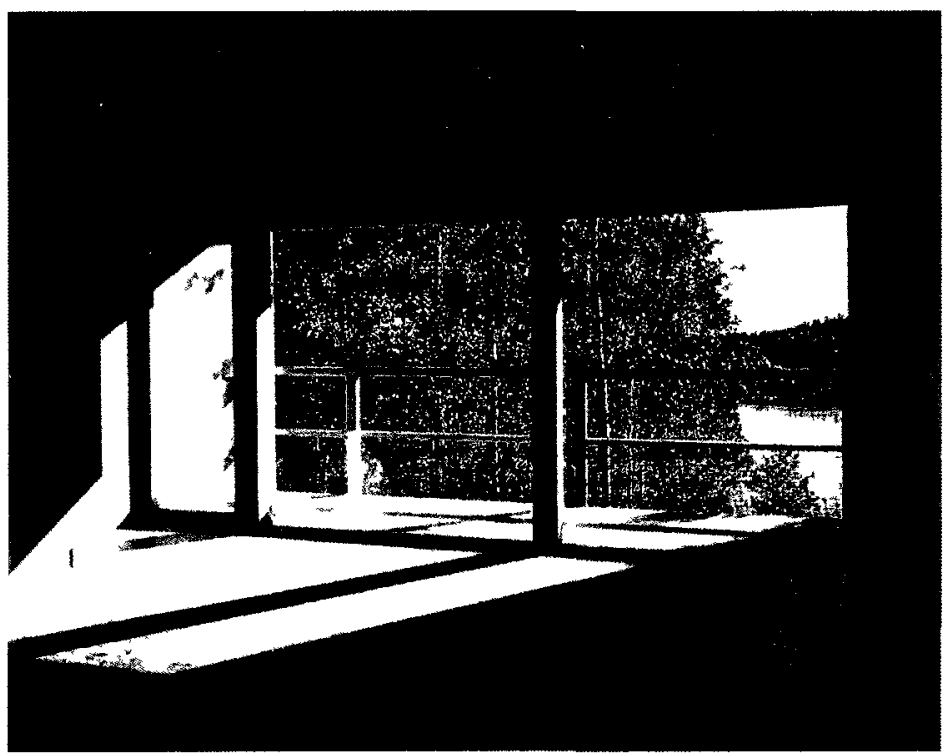

Illustratıon 36 Villa Lınnanmakı, upstaırs 


\section{Main Floor}

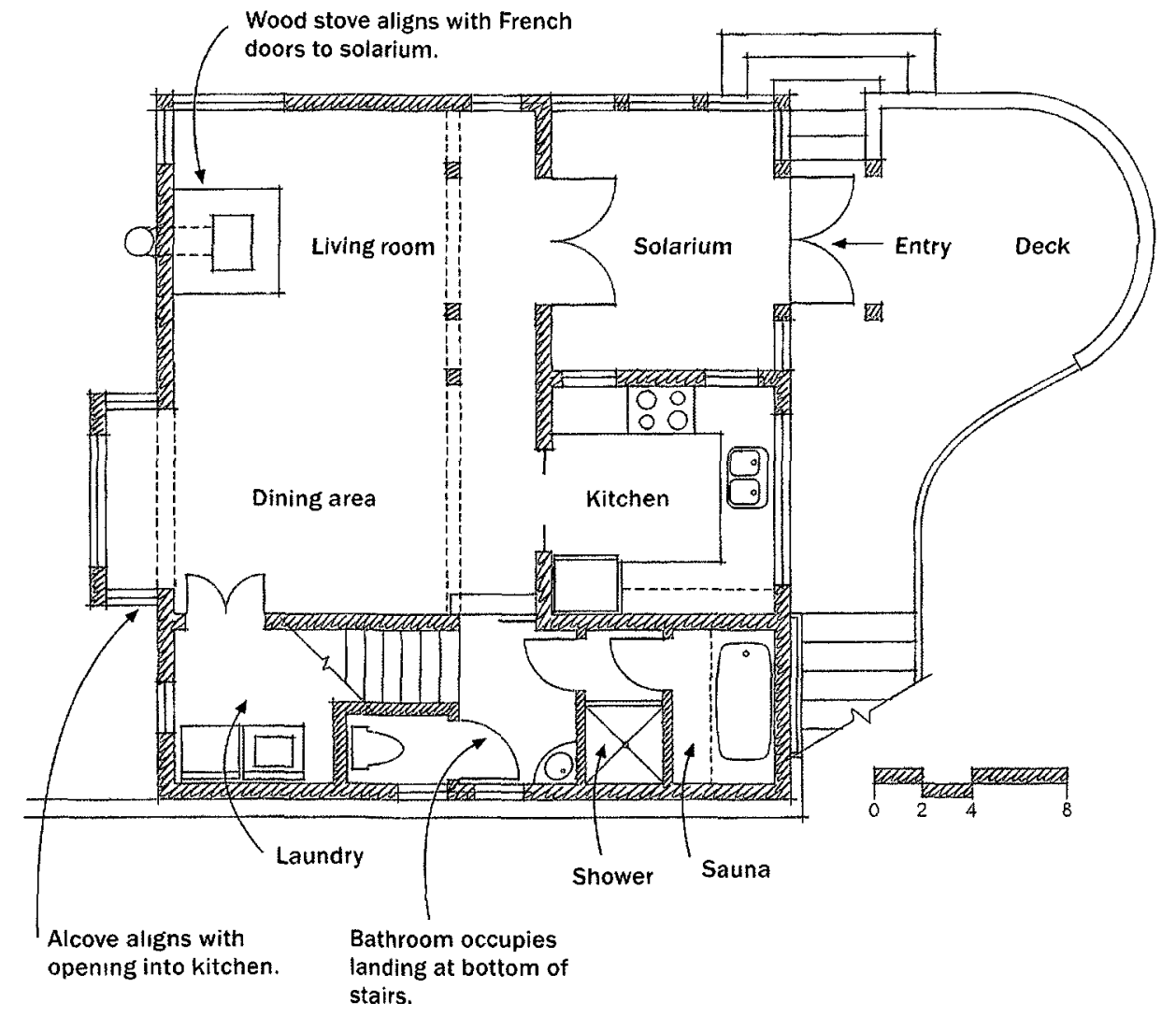

Illustration 37: Home in the Woods, ground floor plan
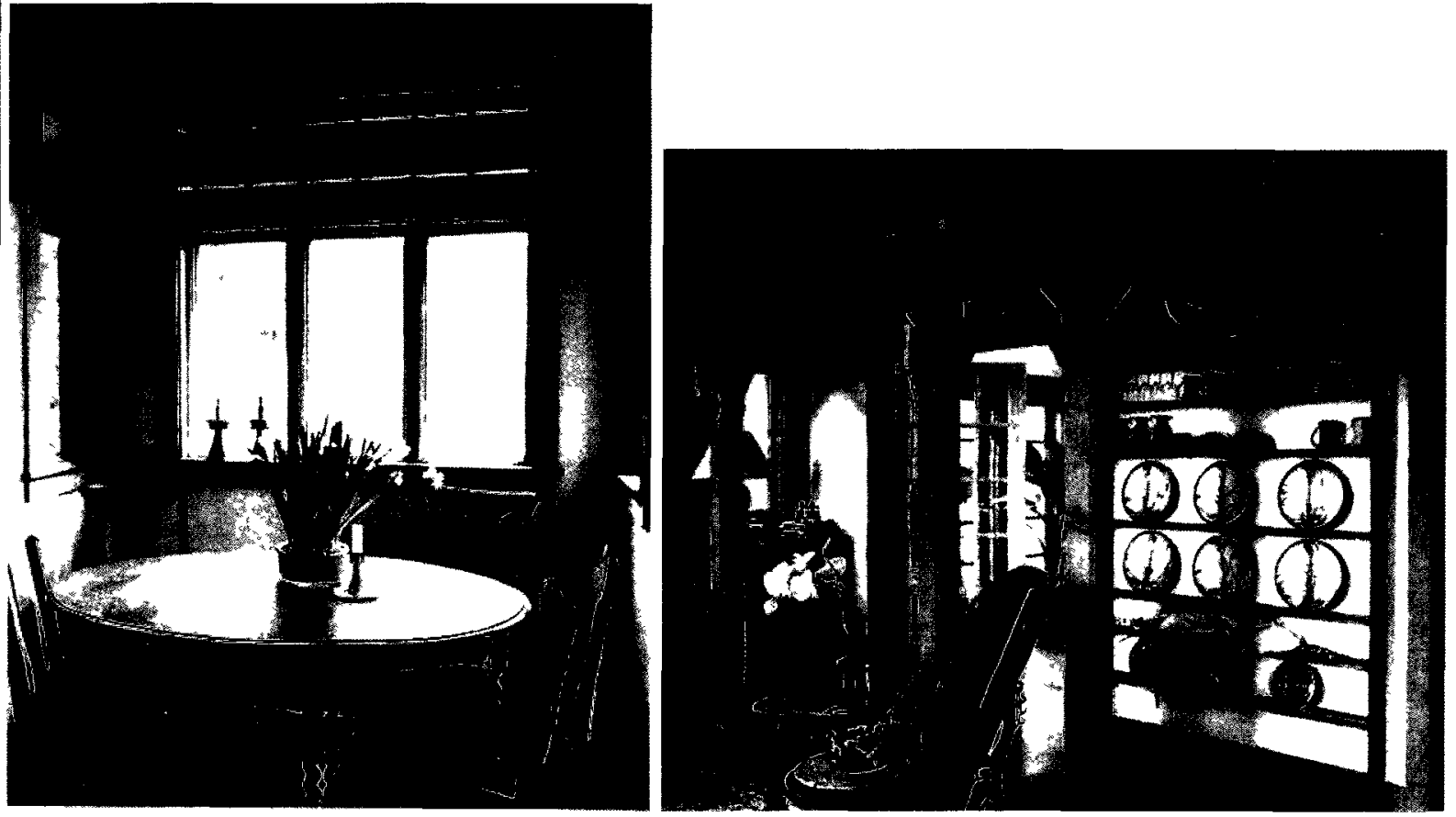

Illustration 38: Home in the Woods, Dining Room, right, connection into the solarium

IIIustration 39: Home in the Woods, using the walls as storage and diplay case 


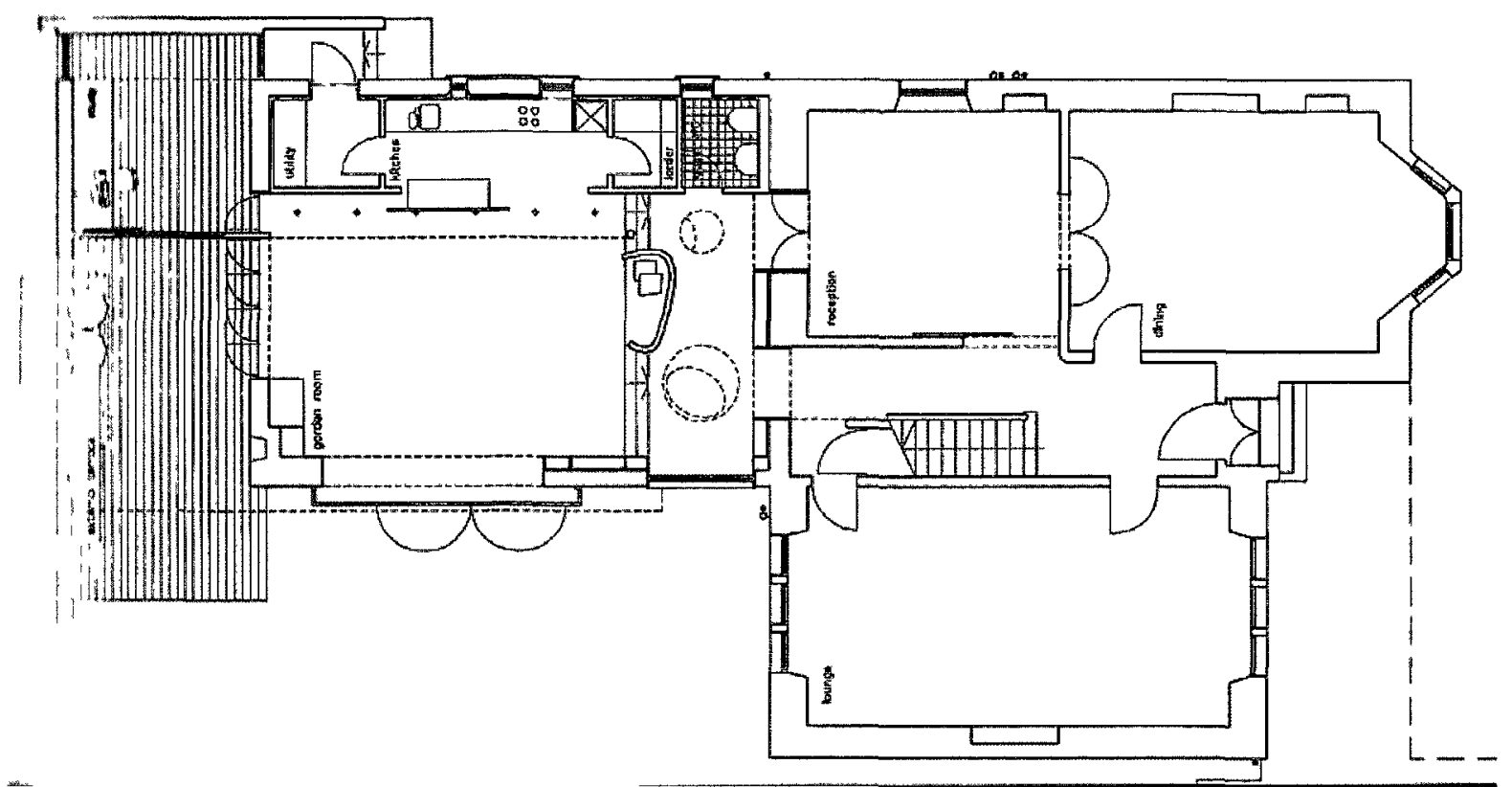

IIIustration 40: Waddel House, ground floor plan with addition

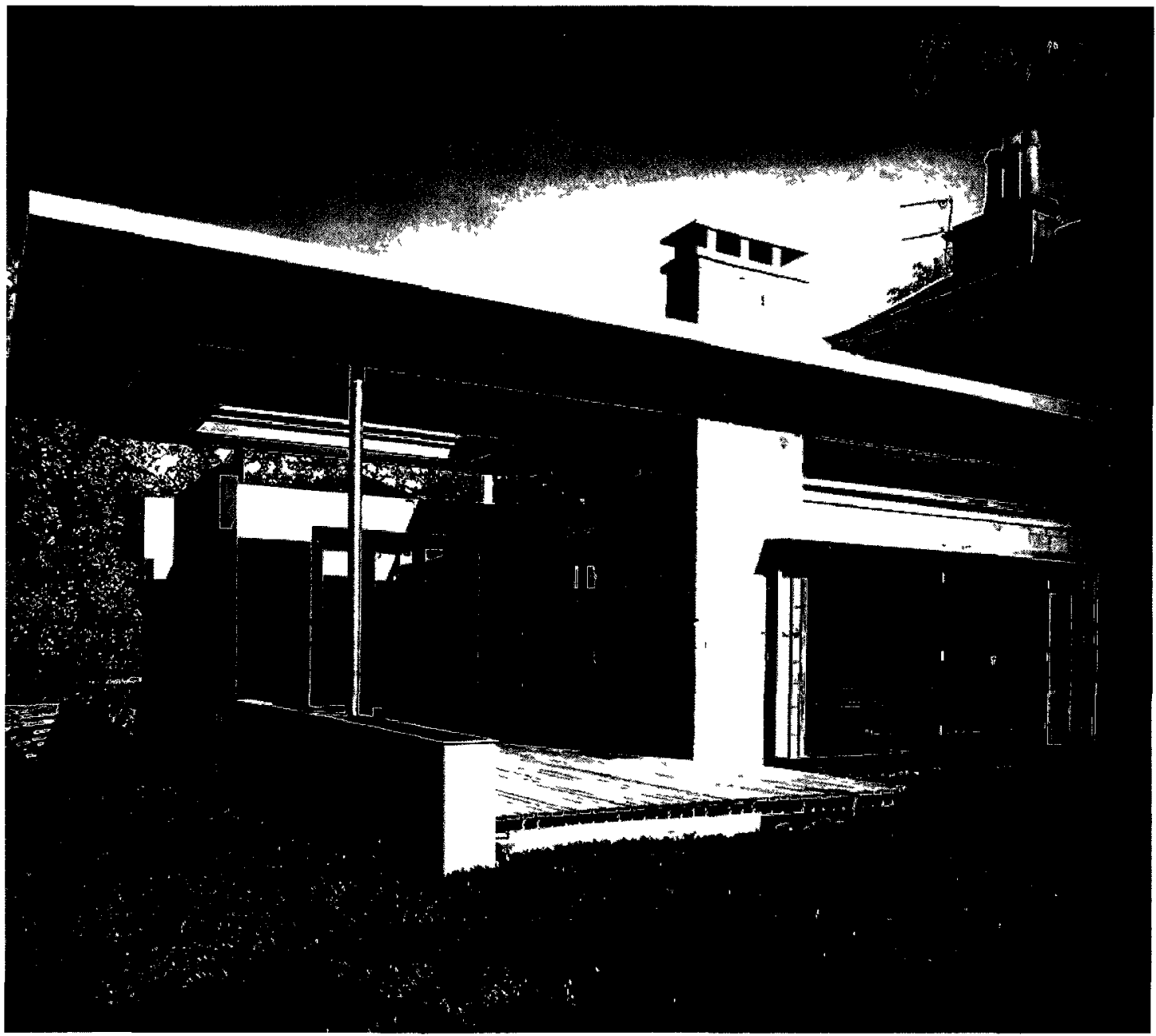

IIlustration 4l: Waddel House, addition 

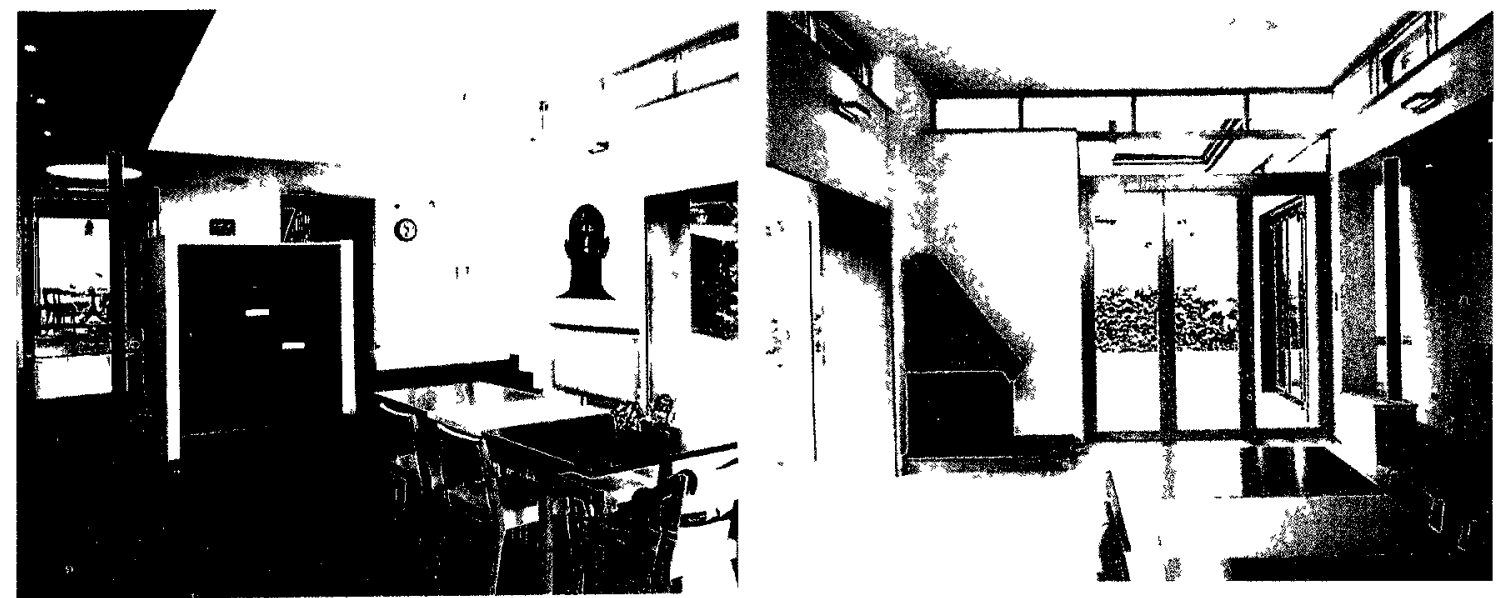

Illustration 42: Waddel House, view from addition to existıng house, right, view from existing house to addition

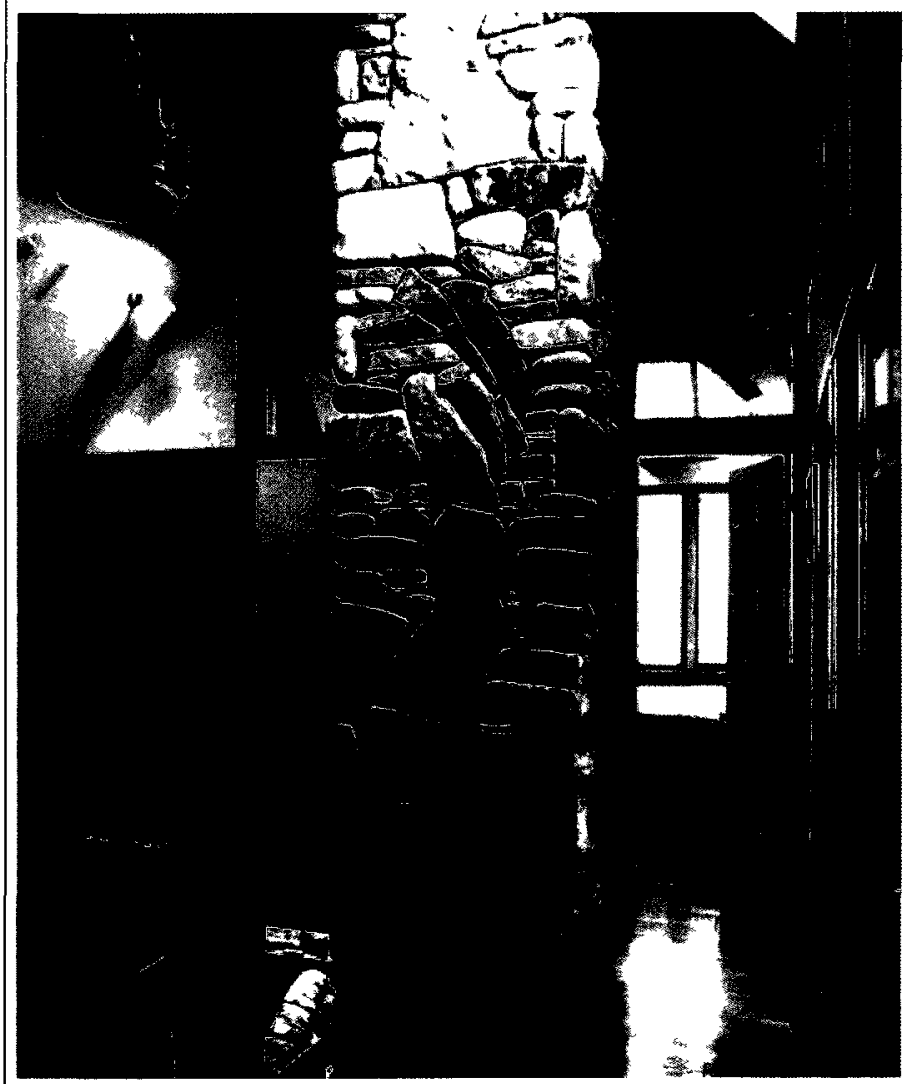

\section{Upper Floor}

FIRST PHASE

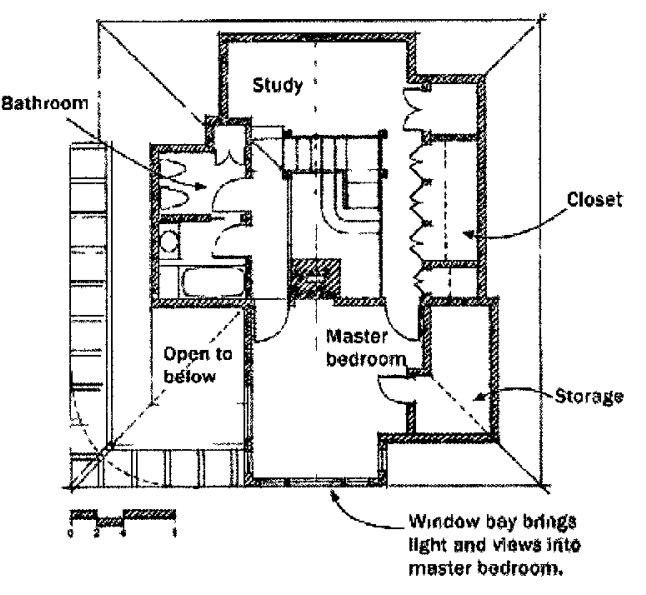

Illustration 43: Vacation house, Upstairs hallways, similar light to study, right, the relatıonship between the upstairs hallway and study 


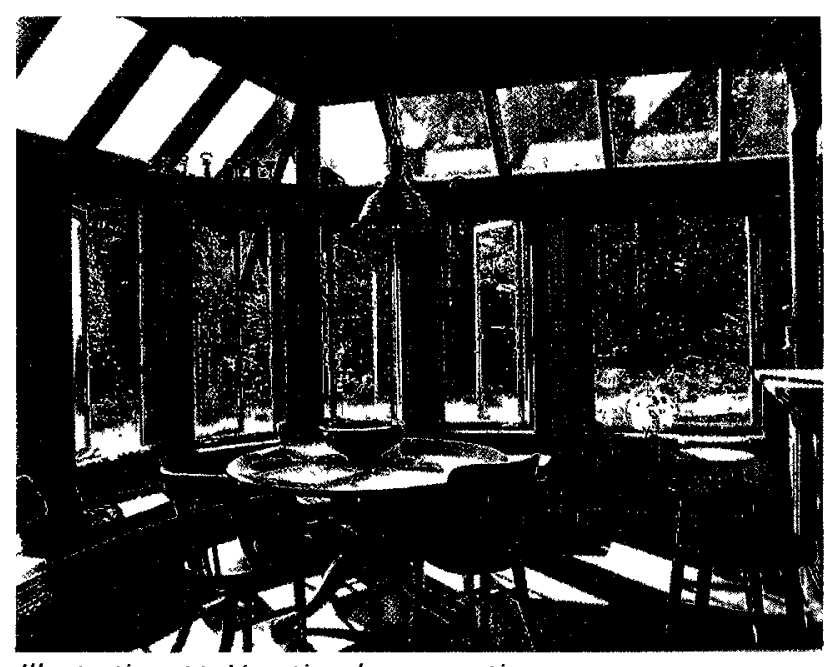

IIIustration 44: Vacation house, eating area

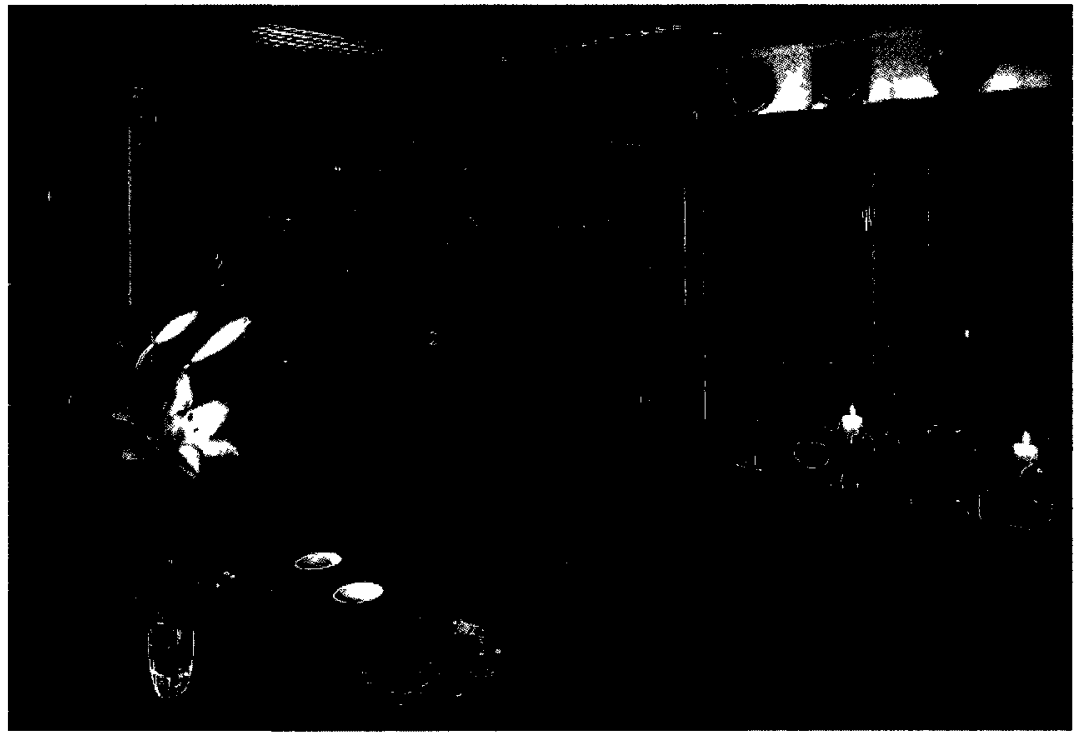

Illustration 45: Lighting accentuating the eating area

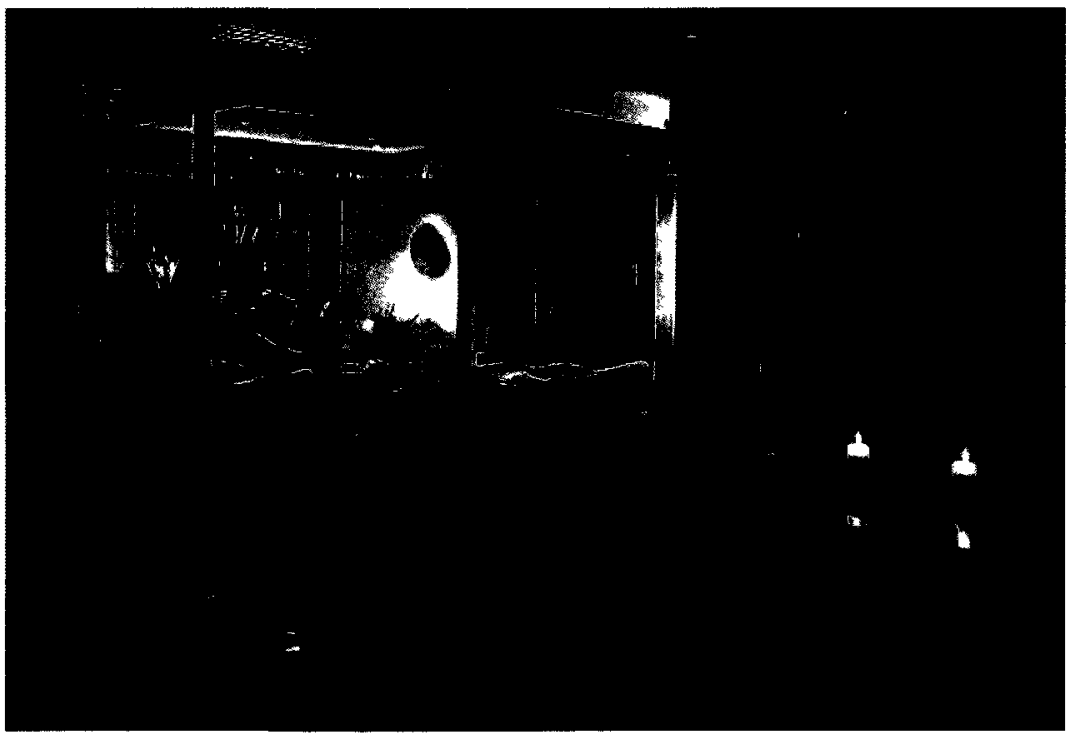

Illustration 46: Lighting accentuating the living area 


\section{Chapter 4 The Site}

\section{The Story}

Located on the outskirts of downtown Ottawa, Ontario, Hintonburg boasts an interesting history. Hintonburg began with the building of Richmond road in 1818 by the military to connect Richmond Landing on LeBreton Flats, to the town of Richmond, so named for the Duke of Richmond. Villa estates lined Richmond, some of which belonged to Judge Armstrong, Judge Ross (eventually to become the Salvation Army Grace Hospital) and Andrew Holland. As the estates were sold off, they were subdivided into smaller plots of land and short roads which gives Hintonburg its charm. The economic boom of 1890 , and the introduction of the streetcar in 1896 saw the population of the area grow. Following the fires in the Bayview Yards and Hull on April 26 1900, the french population and diversity of the area increased. In 1907 the suburb was annexed by the city and by the 1920's Hintonburg's Wellington Street was "a thriving main street with several grocery stores; dry good stores; two movie theatres (one of which became a bowling alley); several drug stores, including the Victoria Pharmacy; and numerous other thriving 
businesses" ${ }^{\prime 3}$. Currently, there is a variety of small residential housing in Hintonburg, as well as a bustling main street of small boutiques, theatres, restaurants, and businesses. Though it is essential that we begin to densify to address suburban sprawl, it is also fundamental that we retain the visual and historical qualities of the area.

The site in reference to this thesis (III. 47 ) is in the heart of Hintonburg along Wellington Street, which has a history that is also very significant to the area. The main building on the site began as a small Victorian house (III. 48), though it is currently used as a church and convent. In October of 1895 it was rented out as the New Orphington Lodge, for Catholic children emigrating to Canada, by the Southwark Catholic Emigration Society and Canadian Catholic Emigration Society (later joined and renamed the Catholic Emigration Society). The emigration of children was with the foresight that "children of working-class slums faced a bleak future at home and would be better off starting a new life in the colonies; [philanthropists] were committed to the idea of giving them a 'fair chance' to make something of themselves" ${ }^{32}$. In the society's first year of operation alone, 60 children were brought in two groups and distributed to Catholic homes in need of help on the farm or in the house. If the child was no longer needed, they would be sent back to the society to be redistributed to another home. In some cases a child might have stayed with the same family until he or she was old enough to leave, but in other cases the children were sent to 4 or 5 different homes until they came of age to live on their own. In 1904, as conditions for the boys and girls were noted to be below standard in the small Victorian house, construction of a new additions

31 Leaning, John. Hintonburg \& Mechanicsville: A Narrative History. Ottawa, Ontario. Hintonburg Community Association, Inc. 2003. Pg. 31

32 Rooke, Patricia T., and R. L. Schnell. Discarding the Asylum : From Child Rescue to the Welfare State in English-Canada (1800-1950). Lanham, MD: University Press of America, 1983. pg. 210-15 
(fronting on Wellington St.) was undertaken (III. 49). The Victorian house is described in the inspection report from May of 1904 by G. Bogue Smart as follows:

The accommodation at this Home, I regret to say, is not what it should be. The boys' sleeping quarters consists of one large room in the attic. This room is unfurnished, unplastered, and access to it is had only through a narrow attic stairway. There were some camp beds with mattresses and blankets sufficient to accommodate half a dozen boys, and the balance of the party are obliged to sleep on the floor on very ancient and worn looking mattresses, covered by a blanket and a quilt and a pillow, without a cover, for each. On a hot night this room must be insufferable. In case of fire or other emergency, it would be almost impossible to get the children out unless by jumping from the upper windows. The building throughout is badly in need of renovation. ${ }^{33}$

After the addition, the New Orpington Lodge was renamed St. Georges Home. Up until the First World War, an average of 300 children were immigrated through St. Georges per year. As a result of low employment in Great Britian during the years 1920-21 of World War I, fewer children were sent to Canada, but after the war, the number of children emigrated increased to over 400 a year. This in turn brought another addition fronting on Grant Street to be commissioned (III. 50). However, through lobbyists and governmental debates, the emigration of children from Britain slowed. In March of 1925 the Immigration Branch "ruled that children unaccompanied by their parents would not be admitted to Canada under the age of fourteen for three years" ${ }^{34}$. This became law in 1928. When the depression hit Canada, fewer people were willing to open their homes to more children. In 1930 there were only 100 boys admitted, while no girls admitted at all, as demand for domestic work was

33 NA, C-7356, RG 76, v. 203, file 87308 (2), G. Bogue Smart, Inspection Report, 29 May 1904.

34 Parr, Joy. Labouring Children : British Immigrant Apprentices to Canada, 1869-1924. Toronto: University of Toronto Press, 1994. 131-134 
drastically reduced. By 1932, no children emigrated to Canada through this program. In 1934, St. Georges closed its doors. Of the total 98,000 children who were sent to Canada, 8,228 went through the doors of St. Georges. The Emigration Society sold the property to the Archbishops of Southwark and Liverpool, but the home stayed closed until 1940 until it was rented to the Department of National Defence (Navy) for experimental research. After the war, the home then again stood empty until it was sold in 1946 to the Archdiocese of Ottawa as a rectory for the Queen of Most Holy Rosary parish. Since then, the back portion of the home has been renovated to fit the function of a church (III. 51 ans III. 52), while the 1904 Wellington addition serves as a convent. Presently, with around 200 families making up the congregation of the Queen of the Most Holy Rosary parish is still growing, and holds services 6 days a week to accommodate them. 


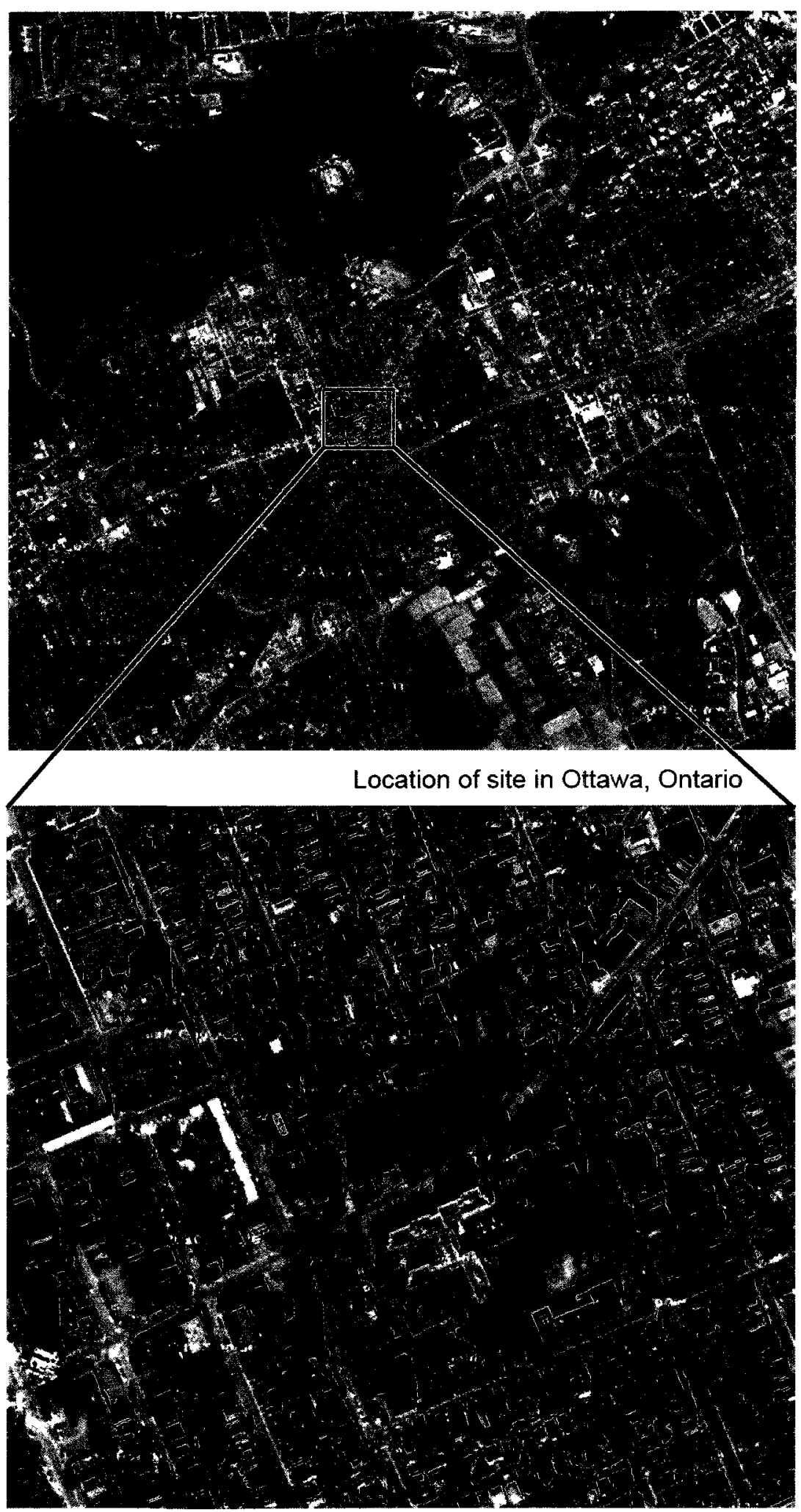

Illustration 47: Locations of site in Ottawa, Ontario 

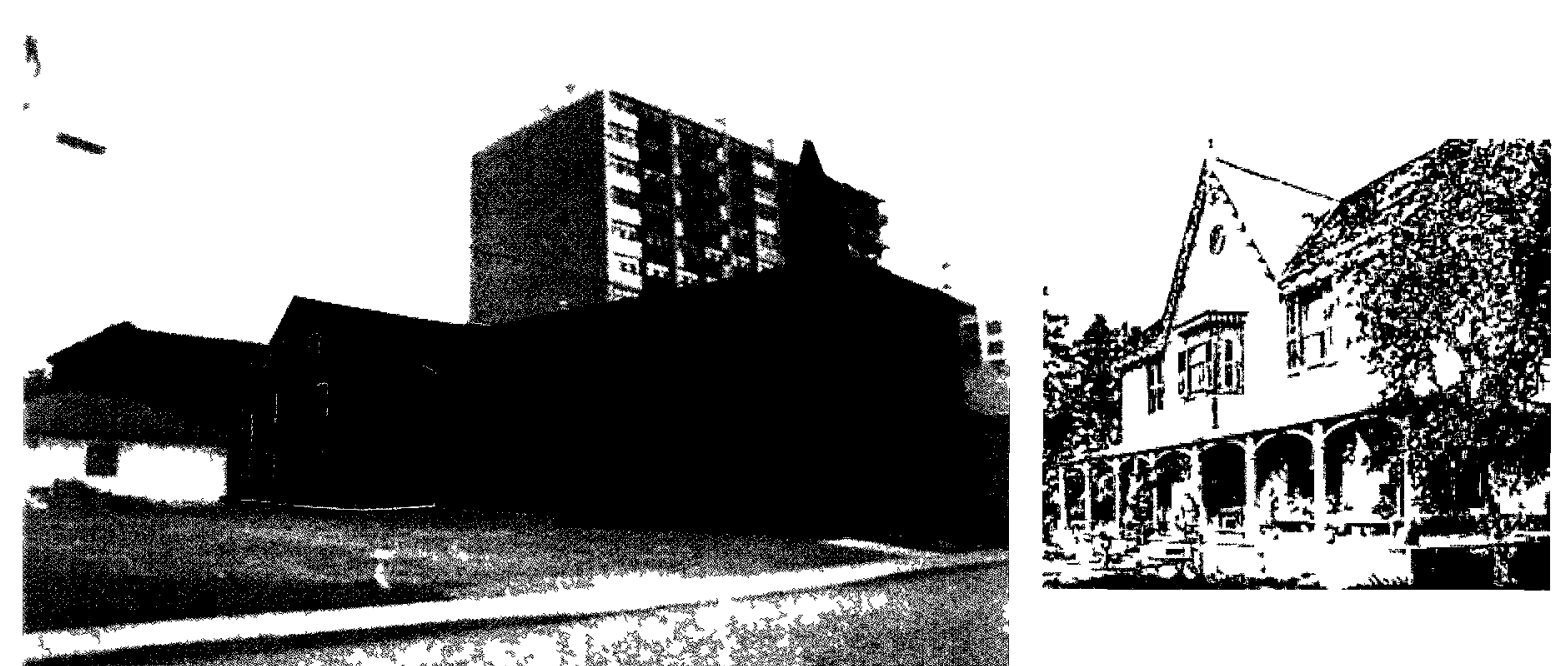

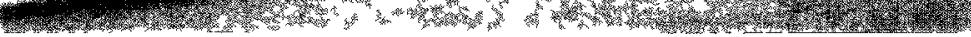
Illustration 48 Original 1800 s Victorian House, left - current, right original front facade

+

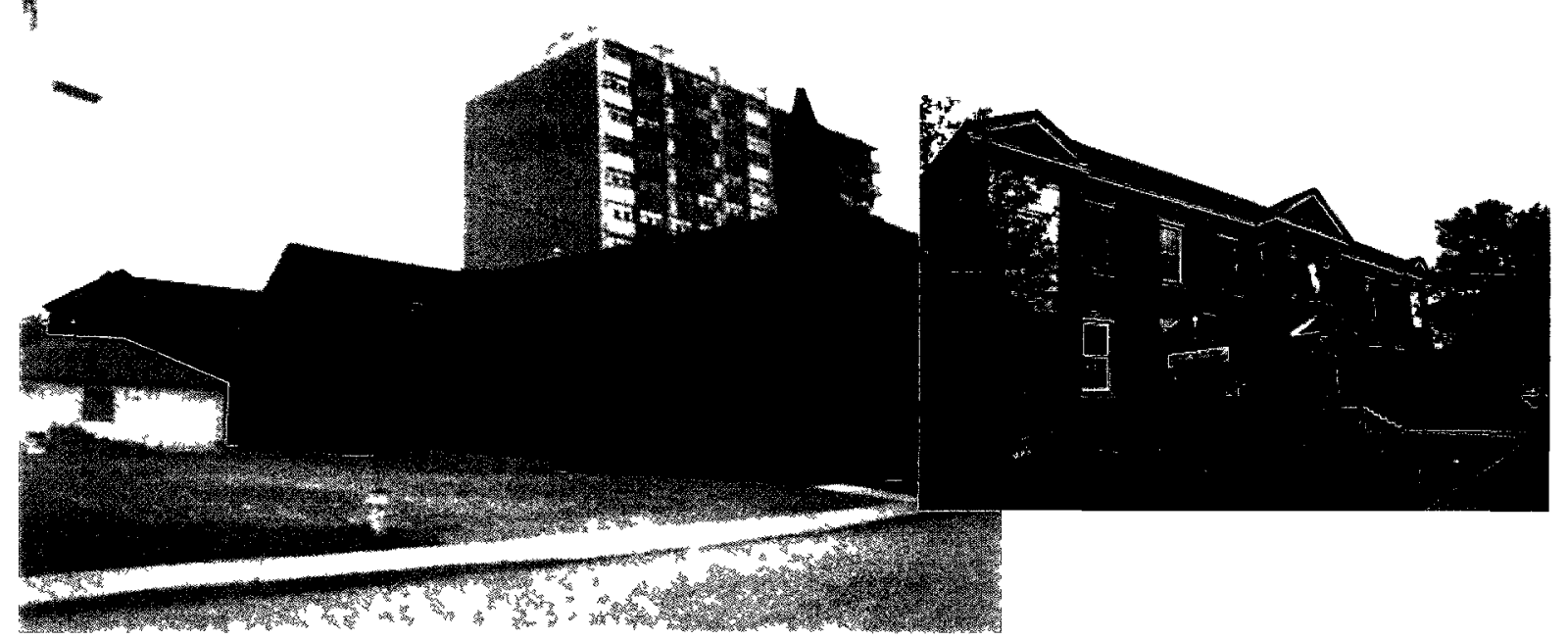

IIIustration 491904 addition, left - connection to existing Victorian

house, right front facade

$-$

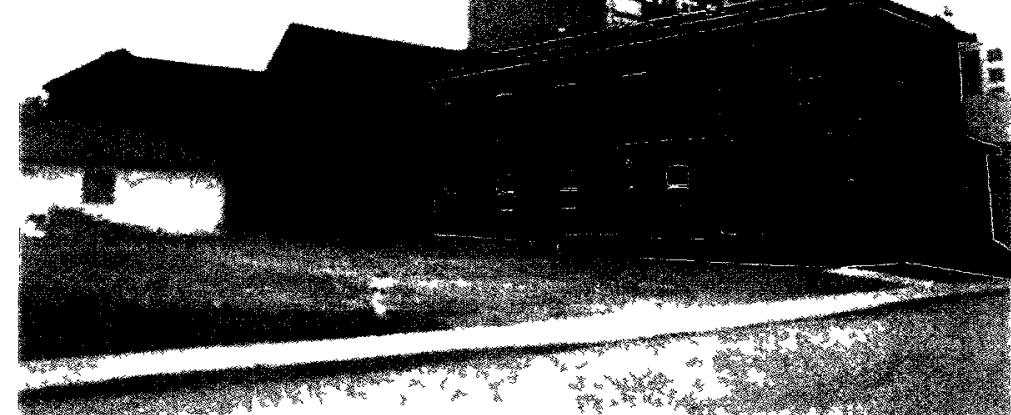

Illustration 50 1920s addition, left connection to Victorian house

right, Grant Street Facade

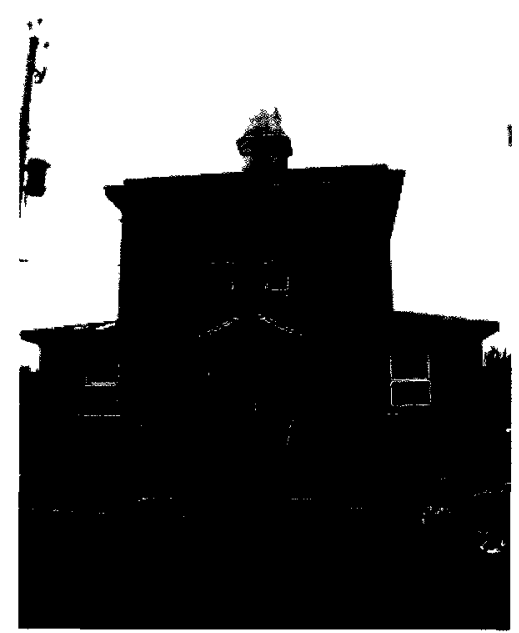




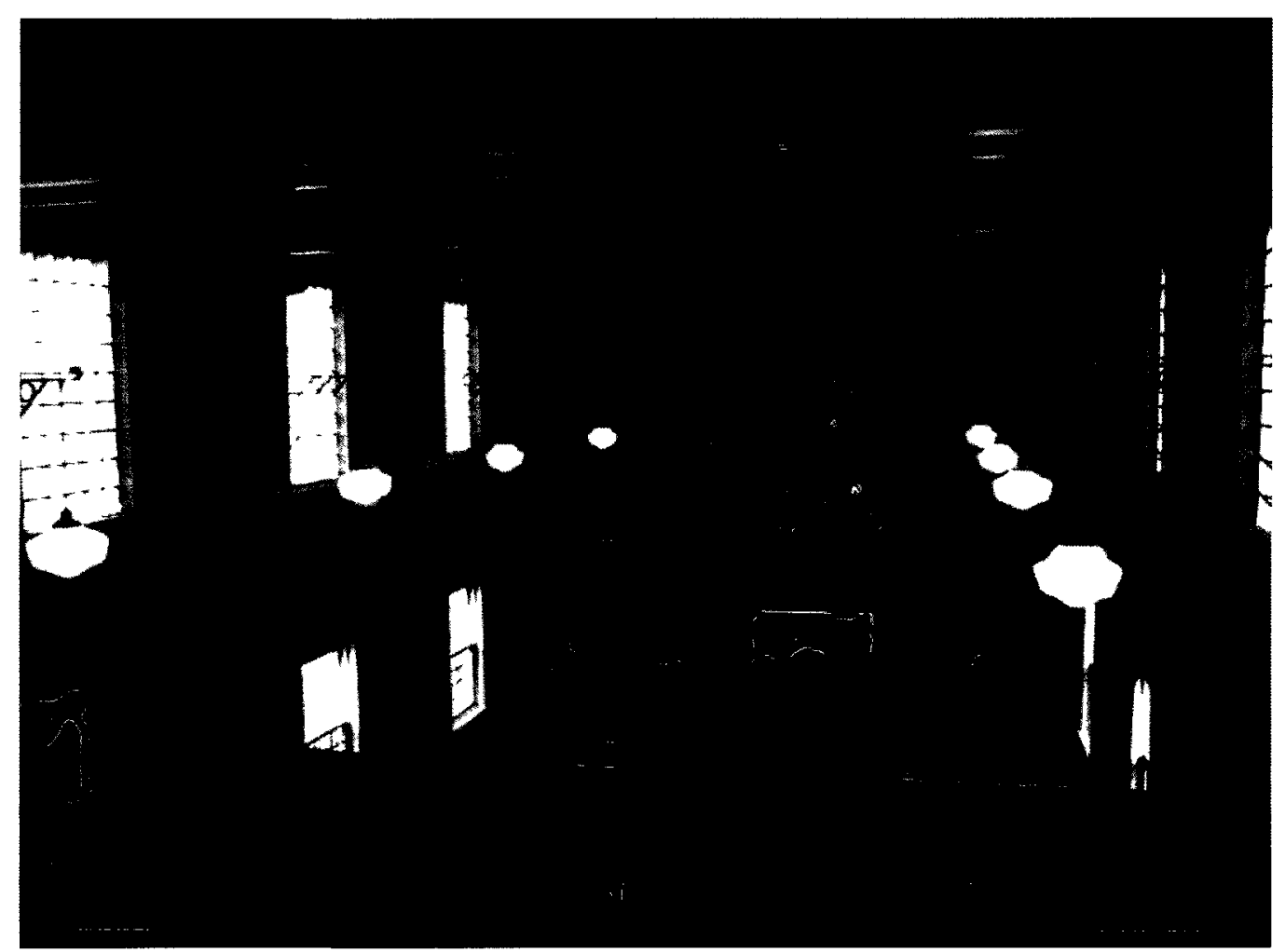

IIIustration 51: Interior view of nave (within the 1920's addition) from balcony

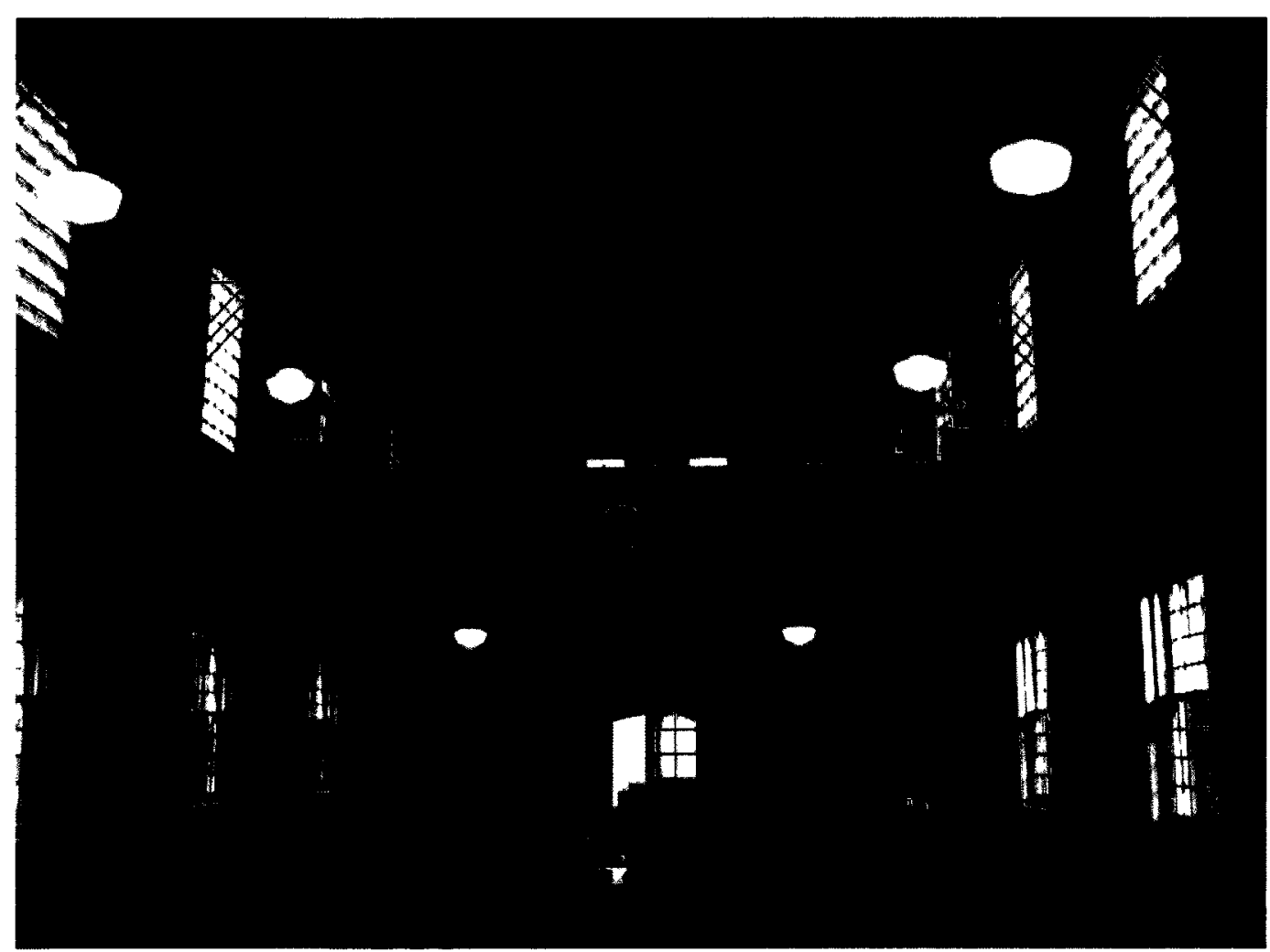

Illustration 52: Interior view of balcony, looking towards Grant Street 


\section{Overview of Project}

In order to explore the use of space-metaphors in a project of architecture, I am proposing a combination of commercial, community, and private space. Currently, along with the church previously mentioned, there is a parking lot, and a Royal Bank of Canada branch on the site (III. 53). As the Hintonburg community is gradually expanding and becoming livelier, this site is being drastically under used. In recent years, Hintonburg has become known as the artistic area and is now promoting small business boutiques, creative corner art pieces placed on the side walks, and even establishing Quartier des Artists/Arts District (QUAD), which has helped promote cultural facilities such as galleries, theatres, and rehearsal spaces (III. 5456). As part of my proposal, the Royal Bank of Canada will continue to function on the site, but within a complex of other commercial spaces which will harmonize small businesses and entrepreneurs with live/work studios above for artists, and corresponding exhibition spaces. The Grant Street address of the church will be appropriated as a community centre, while the Wellington Street address will be used as a bed and breakfast. Lastly, there will be two more additions to the site, a pool for the community centre, and a residential complex (III. 57). While respecting the site for what it is, the overall planning aims to create a sustainable, liveable, and collaborative community, developed through space metaphors within the Hintonburg area (III. $58 \&$ III. 59). 


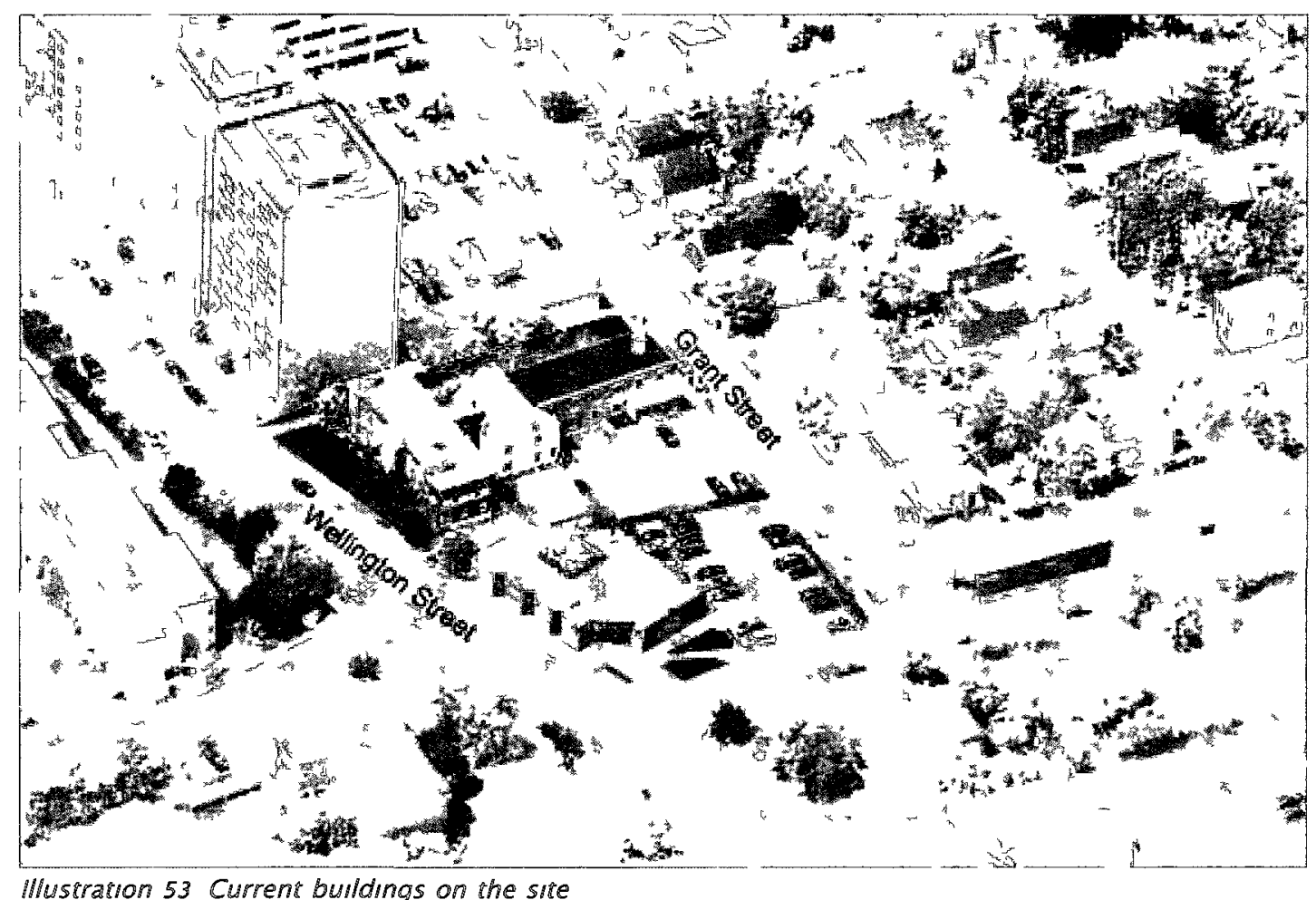

Ilustration 53 Current buildings on the site

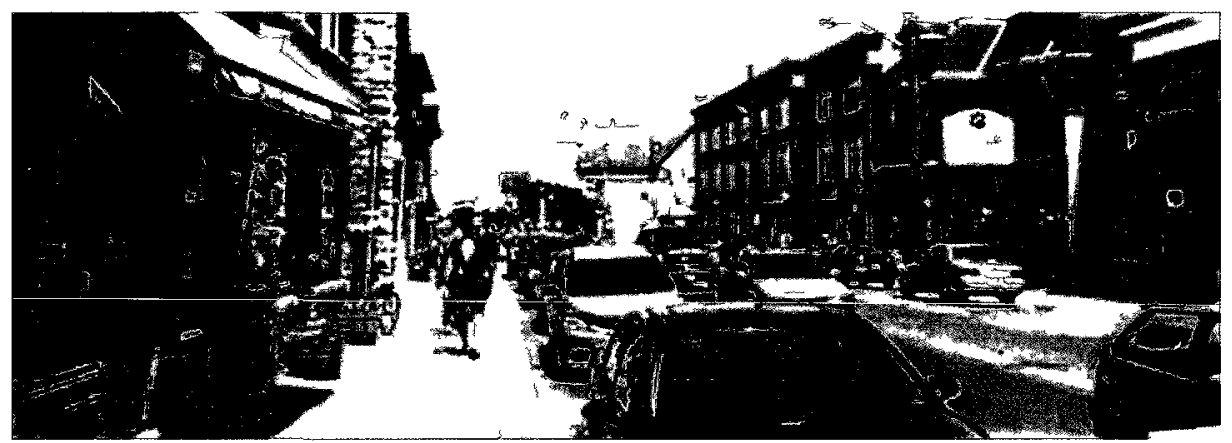

IIlustration 54 A view down Wellington Street

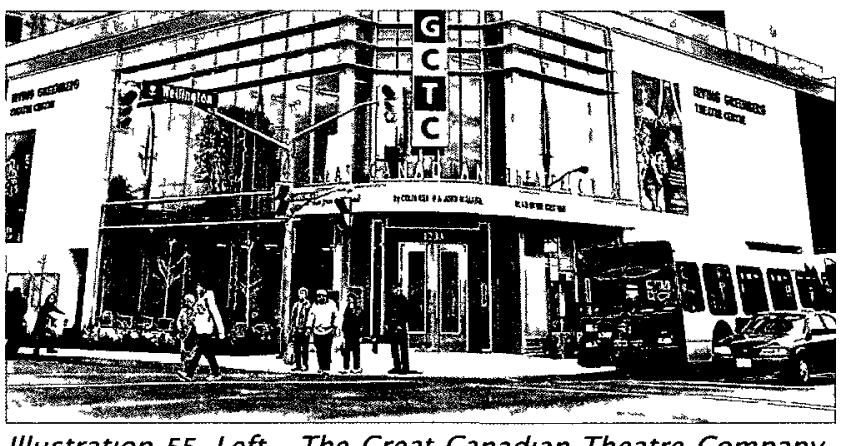

Illustration 55 Left - The Great Canadian Theatre Company, right - the Parkdale market

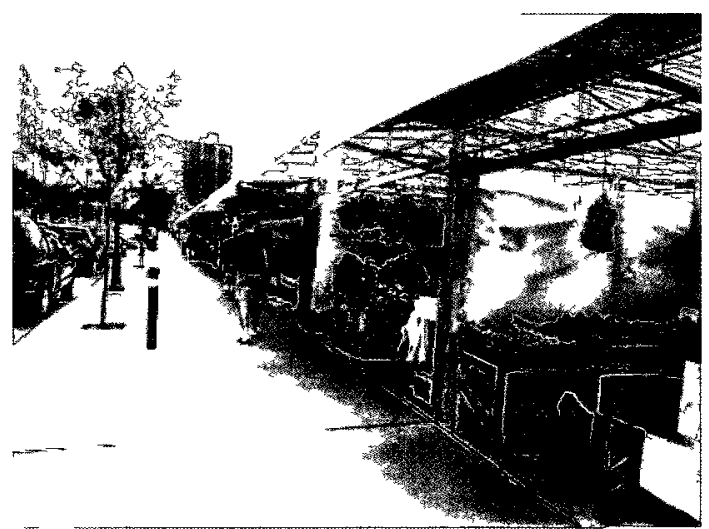



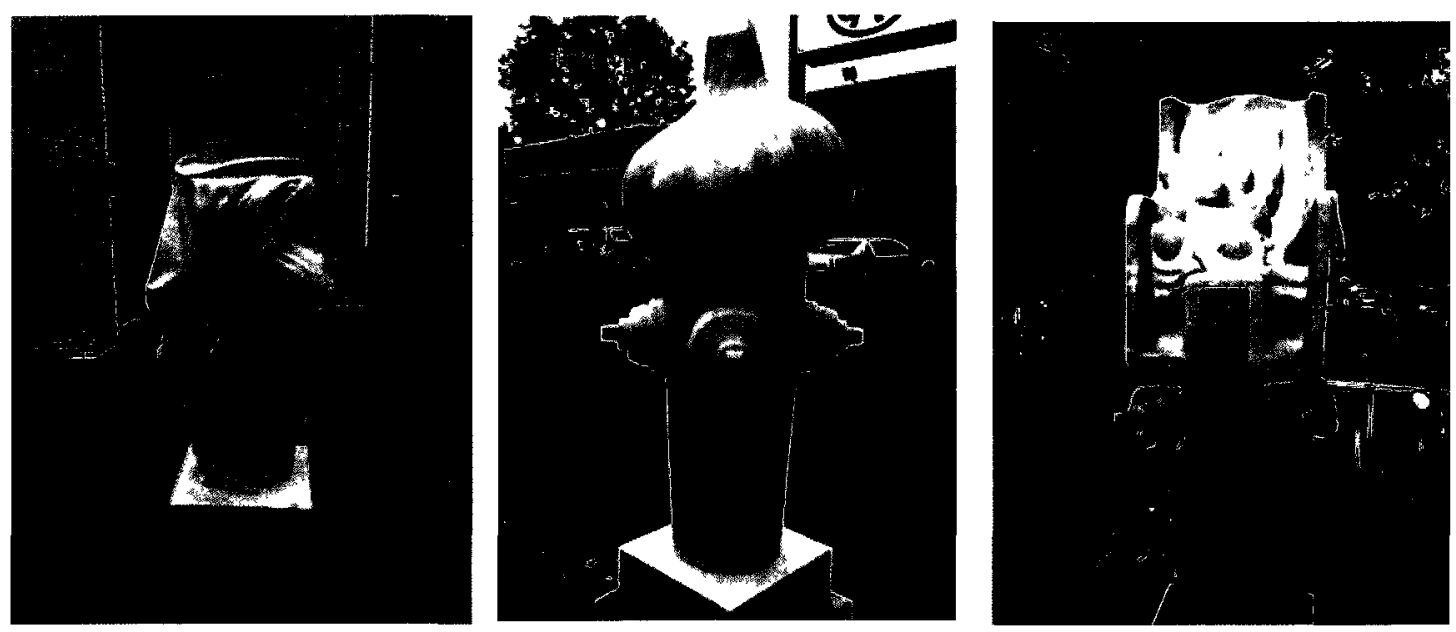

Illustration 56: A sample of

street corner sculptures by

Marcus Kucey Jones and Ryan

Lotecki, 18 in total are dispersed

around the Hintonburg area

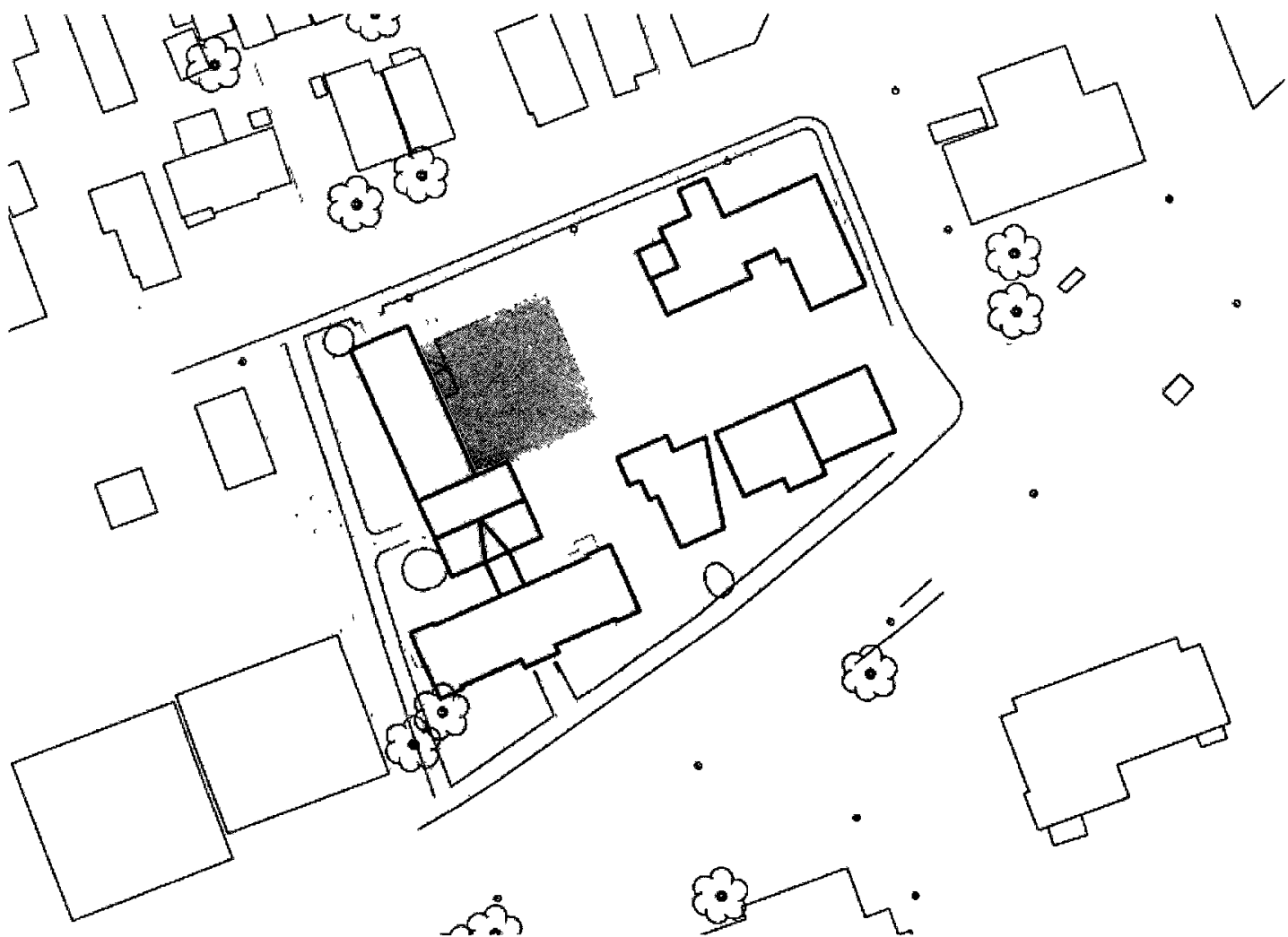

Illustration 57: Site plan of proposed design, red - community centre, blue - new pool, green - new residential, light blue - commercial/artists residence/gallery, purple - bed and breakfast 


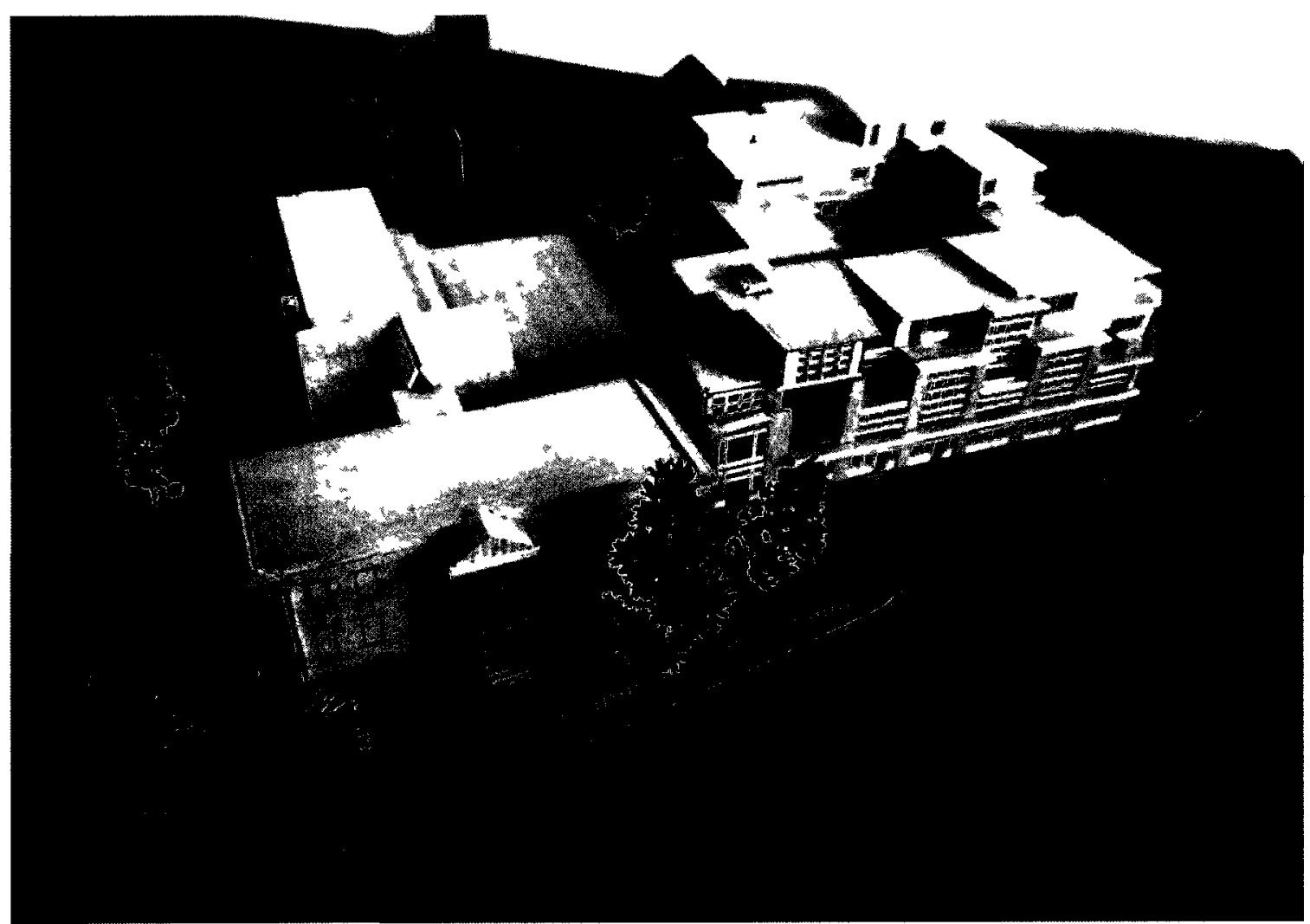

IIIustration 58 Bass wood model, Wellington Street view

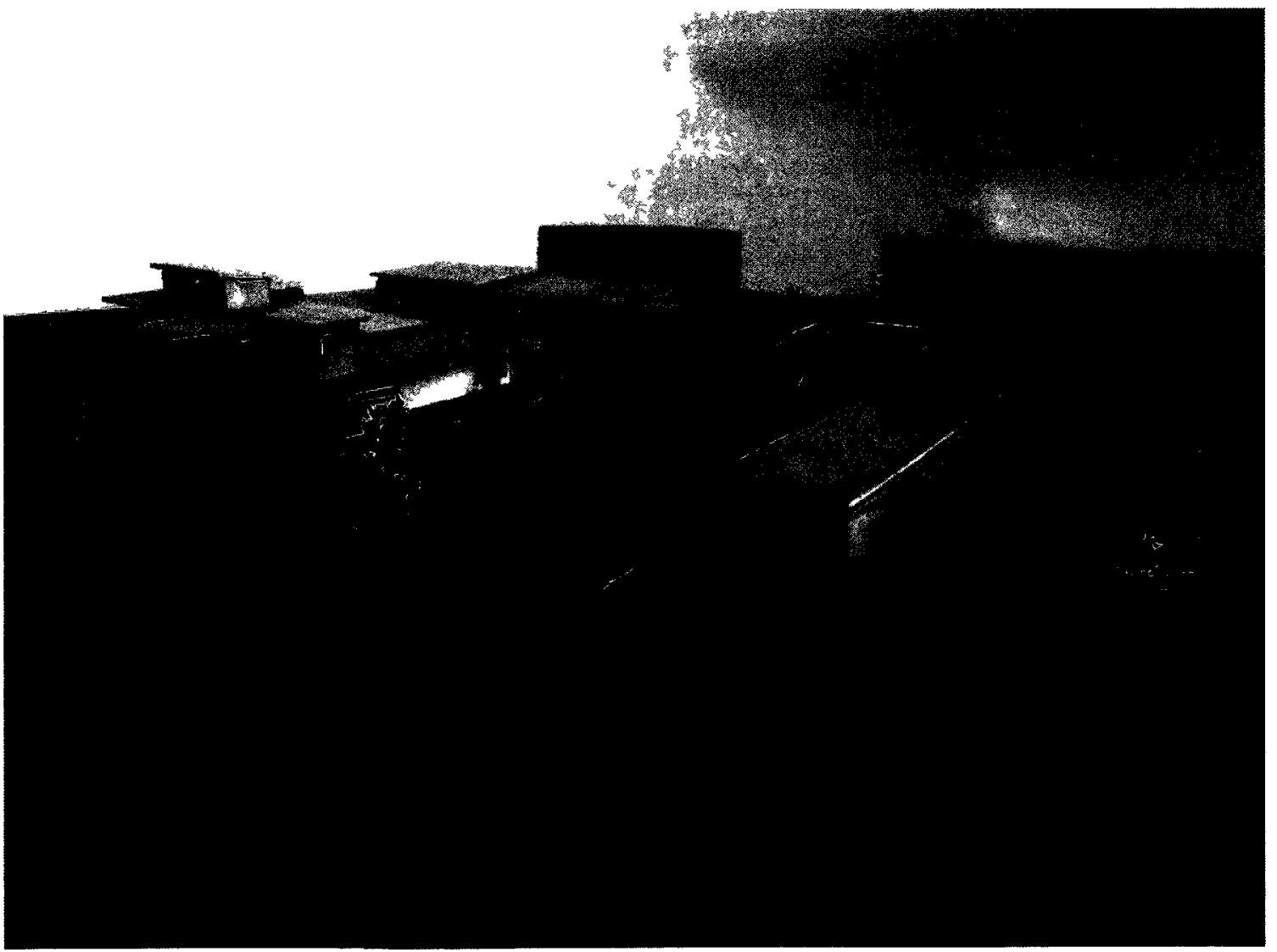

IIIustration 59 Bass wood model, Grant Street view 


\section{Church as Community Centre}

For the past 60 years, this church has served its community well, as a place of worship. Even though the building has served its purpose well up to this point, it has gone beyond its intended use. As the congregation increases, and with the popularity of the area increasing, a major renovation to the building will be needed whether it is kept as a church or not. The growth of the congregation provides the church with a unique opportunity to build a new institution that could hold the growing congregation and build for the future. Though the proposed new function of the building would no longer be a church, it would continue to serve the community. As a community centre, the main open space that was once the nave of the church, can serve as a daycare centre, summer day camp, as well as a space for community events. With the addition of a pool, the space can also turn into a recreation facility for Hintonburg.

So as not to overpower the existing building, the pool is situated in the basement level of the church. Large windows near to roof of the pool allow lots of light into the space, while allowing the interior to still be private (III. 60). The basement of the church houses the change rooms and wash rooms for the pool and community centre, while the upstairs is left free for large functions and a multi-purpose space (III. 61). The roof of the pool lands at the bottom of the first floor windows to allow for a spacious height above the pool, keeping a low profile on the outside and function as an outdoor terrace accessed from the community centre and exterior for the community. 


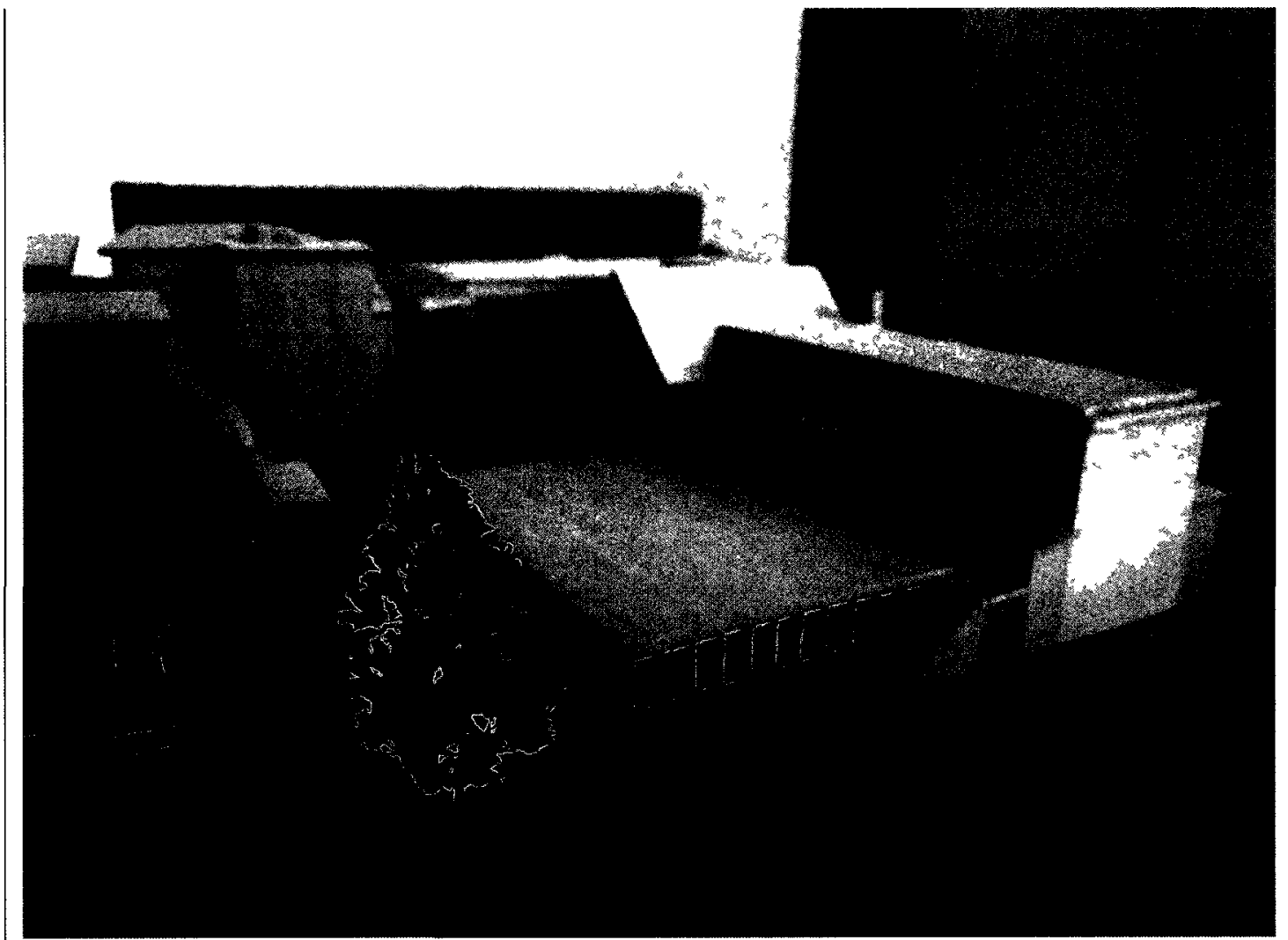

IIlustration 60: Exterior view of new pool addition

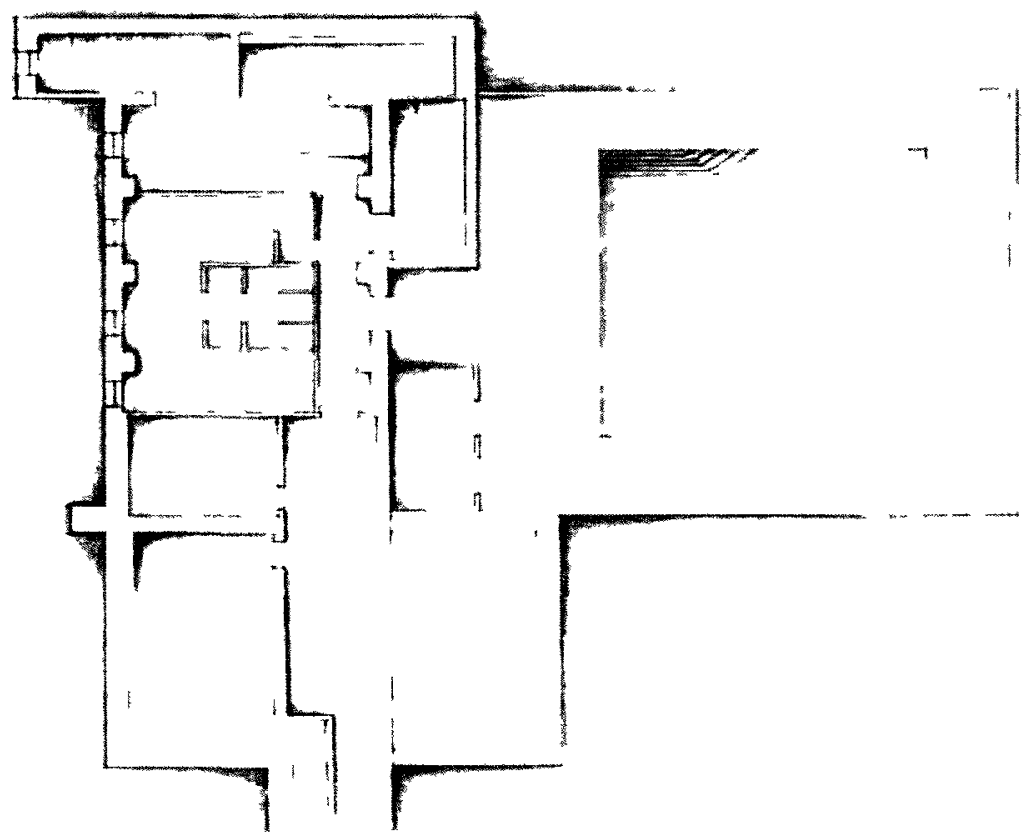

IIIustration 61: Basement plan, showing pool and corresponding amenities 


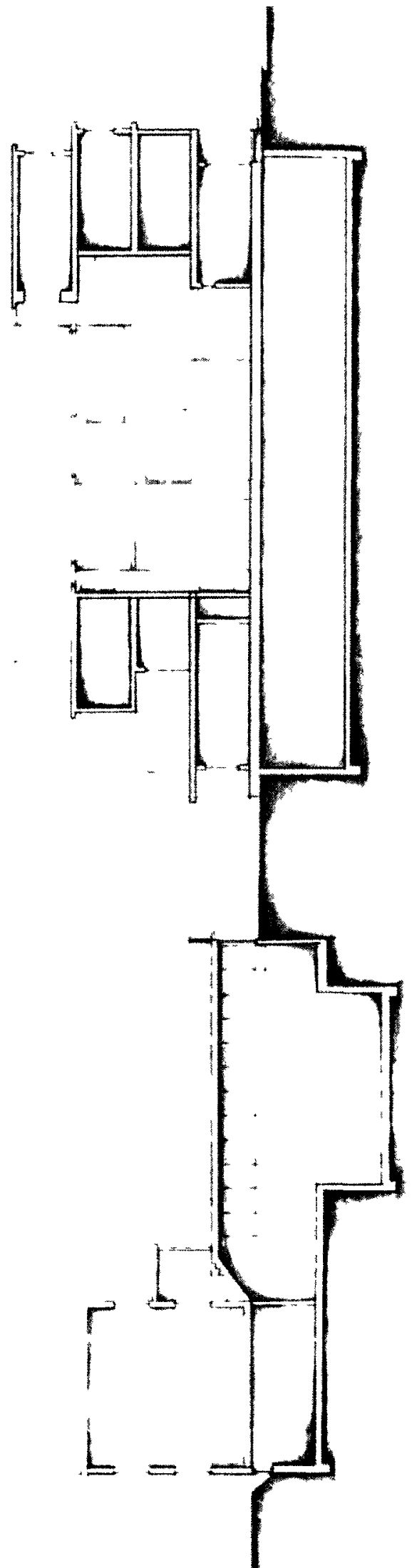

Illustration 62: Section through the Community Centre showing relation of pool to the centre, and access to the roof terrace from the interior 


\section{Bed and Breakfast}

The 1904 addition, fronting Wellington Street, has a very strong presence on the street scape (III. 63). Standing for more than 100 years, the building has become an icon of the area, and should be rightly preserved for the community as well as for its historical literacy. The typology of this front part of the building is very different from the rest of the building. The front, was not only the façade for the Catholic Emigration Society, but also included the kitchen where girls learnt household skills, administrations rooms, and dining spaces for all the children. This building also incorporated sleeping quarters for the employees who looked after the children, taught them, and ran the office. As a bed and breakfast, all of the utilities of the front building can be used, and the integrity of the building can be withheld. The buildings would stay public for anyone wishing to visit the historic site, and would also serve the community by providing room for guests and tourists. The floor plan

(III. 64) are based off of the 1946 drawings by Auguste Marineau Architect, when the home was converted into a convent. The renovations made in 1946 work well with the program of a bed and breakfast, and no major renovations are required. The bed and breakfast has 7 rooms of various sizes, and a common lounge, and dining room. 


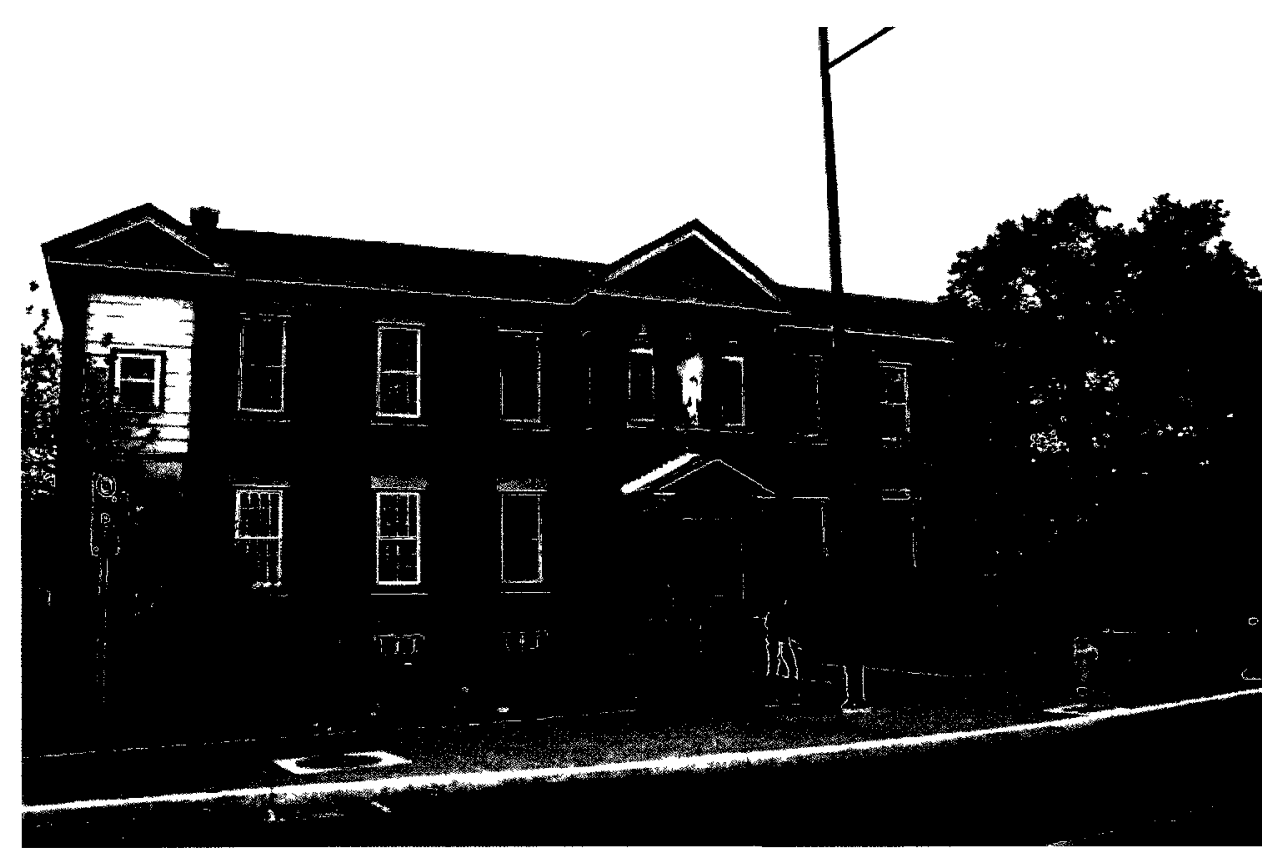

I/lustration 63 Front Facade

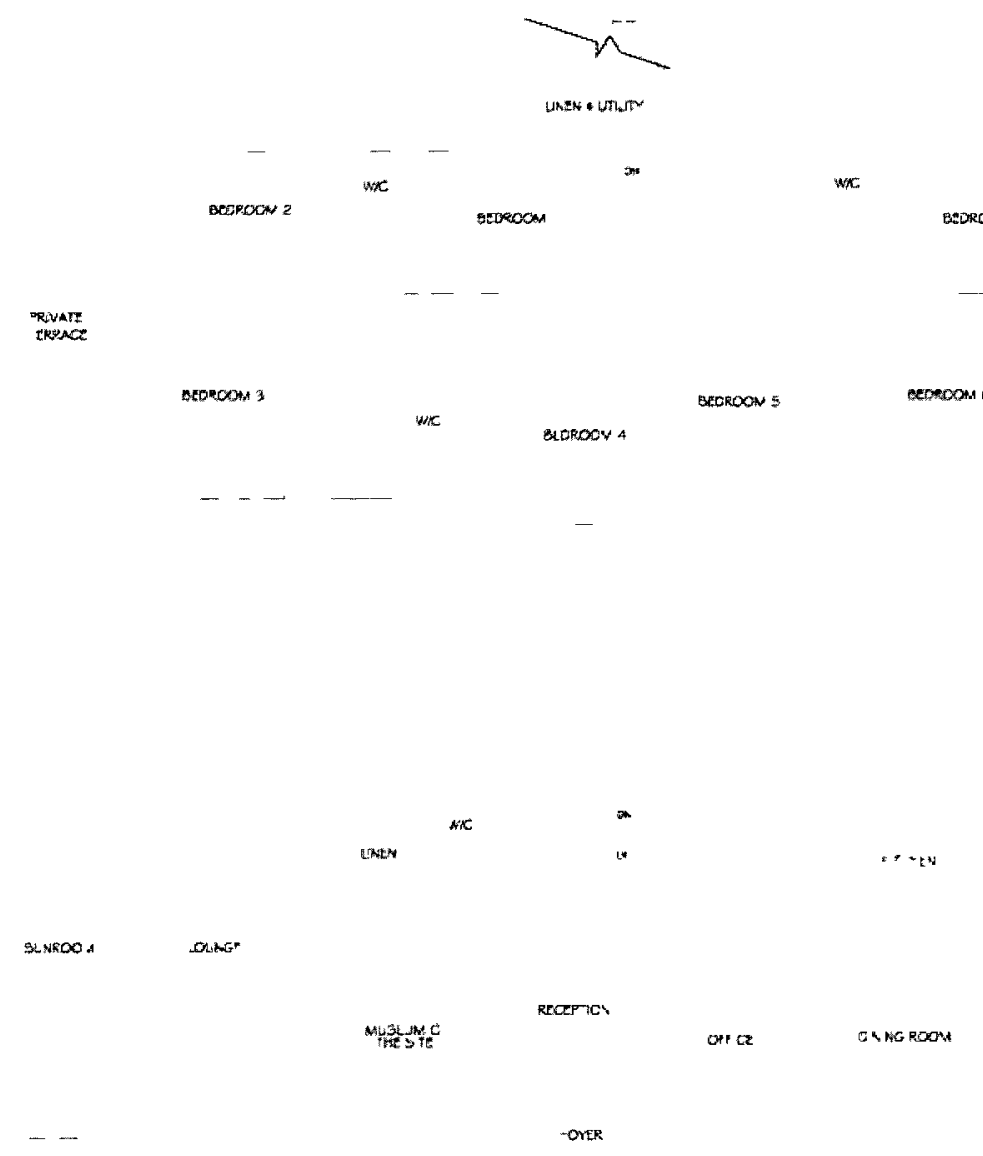

IIlustration 64 Interior floor plans, and room layout 


\section{Commercial}

On the south east side of the site, a new commercial building, artists live/work studios and gallery space is proposed. As a traditional main street, the integrity of the area needs to be held with a strong presence, but not so overbearing that the fabric of the street is lost. With this in mind, the entire ground floor is made for commercial use, since the existing building is pulled back from the street, so should the new commercial building, keeping the urban fabric it is providing for the block (III. 66). The new commercial building also gives an opportunity to provide gallery space and artist live work space above.

Walking into the gallery entrance, the space is double height to accommodate large works of art (III. 65). The main entrance space, coming off the busy street serves as an open area for gatherings, and parties, while as you go higher into the upper gallery spaces they become quieter and contemplative (III. 67). The second level is accessed through the main entrance space, a double height corridor leads to the different studios, private galleries of the individual artists, and 2 outdoor terraces that can be used by the artists, or as gallery space (III. 68 \& III. 69). The double height in the corridor allows for subtle northern light to enter into the studios as well as the living accommodations above, providing light from both sides of the building rather than one. The third floor gallery (III. 70) overlooks the covered terrace at the front, and has an abundance of windows providing natural light to the artwork. The fourth floor gallery (III. 71) has fewer fenestrations, except for a window facing Wellington street, which can work well for light-up artworks, and cinematographic art. At night, this column of gallery space lights up, adding some 
night life to the area (III. 72).

While living close to their work, the artist living spaces each have their own separate entrance off the main corridor to allow for privacy. There are 5 studios, with 4 living accommodations above, 2 which are visually linked to their respective studios. The illustrated live/work studio shows the integrated use of the walls as part of the furniture to hold art supplies, as well a become a temporary exhibition space for small personal exhibitions of the artists.

Illustration 73 shows an example of a live work studio. In this example, materiality is used to highlight the stairs, and provide a central element that can be seen from all rooms in the unit. The concrete blocks of the two stair cases frame the kitchen and eating area alluding to the feeling of being behind something. The built in shelving, overlooking the studio space below can be used for reference materials, as a display case, or both, increasing interaction with the architecture. While light it brought in from both north and south facing windows, the bedroom is located on the north side, where the light is more subtle, allowing the bright intense light to filter into the work spaces. The studio below also uses built in drawers to store paints, pencils, and other materials. The larger shelving above can be used for storing paper or displaying artwork. The studio in front has a fold down table which can be used to work on, or as a central table everyone can see, such as for life drawing classes. These studios also have light entering from both north and south, with the larger work area near the south facing windows. Though small, the assemblage of the rooms allows you to see glimpses of others, increasing the interaction, and discourse with the architecture. 


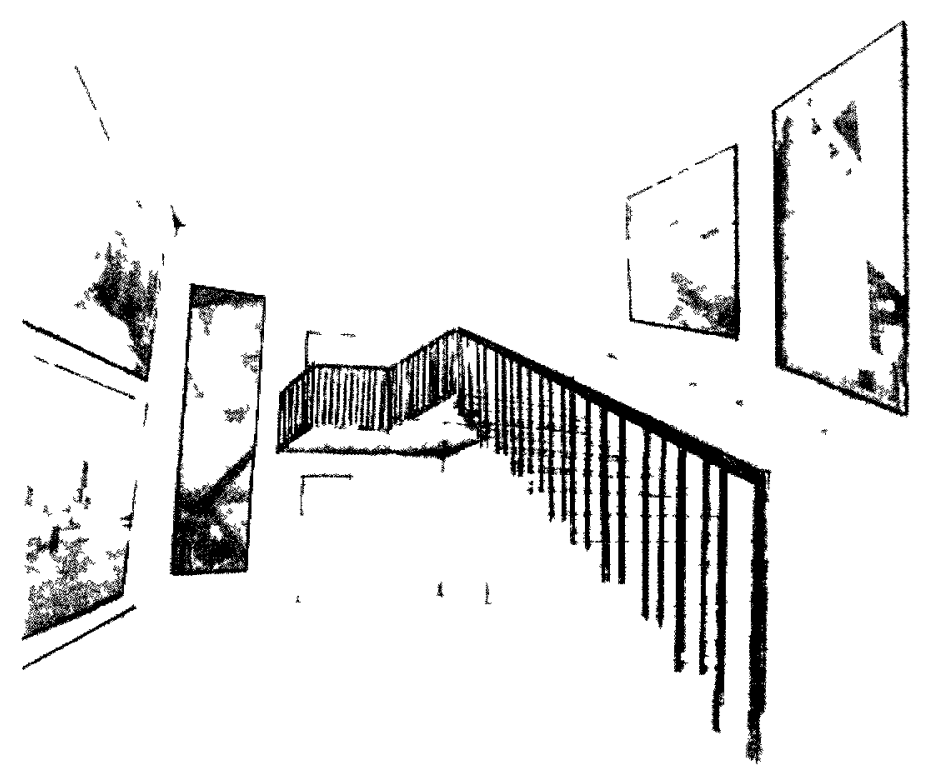

IIIustration $65 \cdot$ Entrance of Gallery and Artists Studios

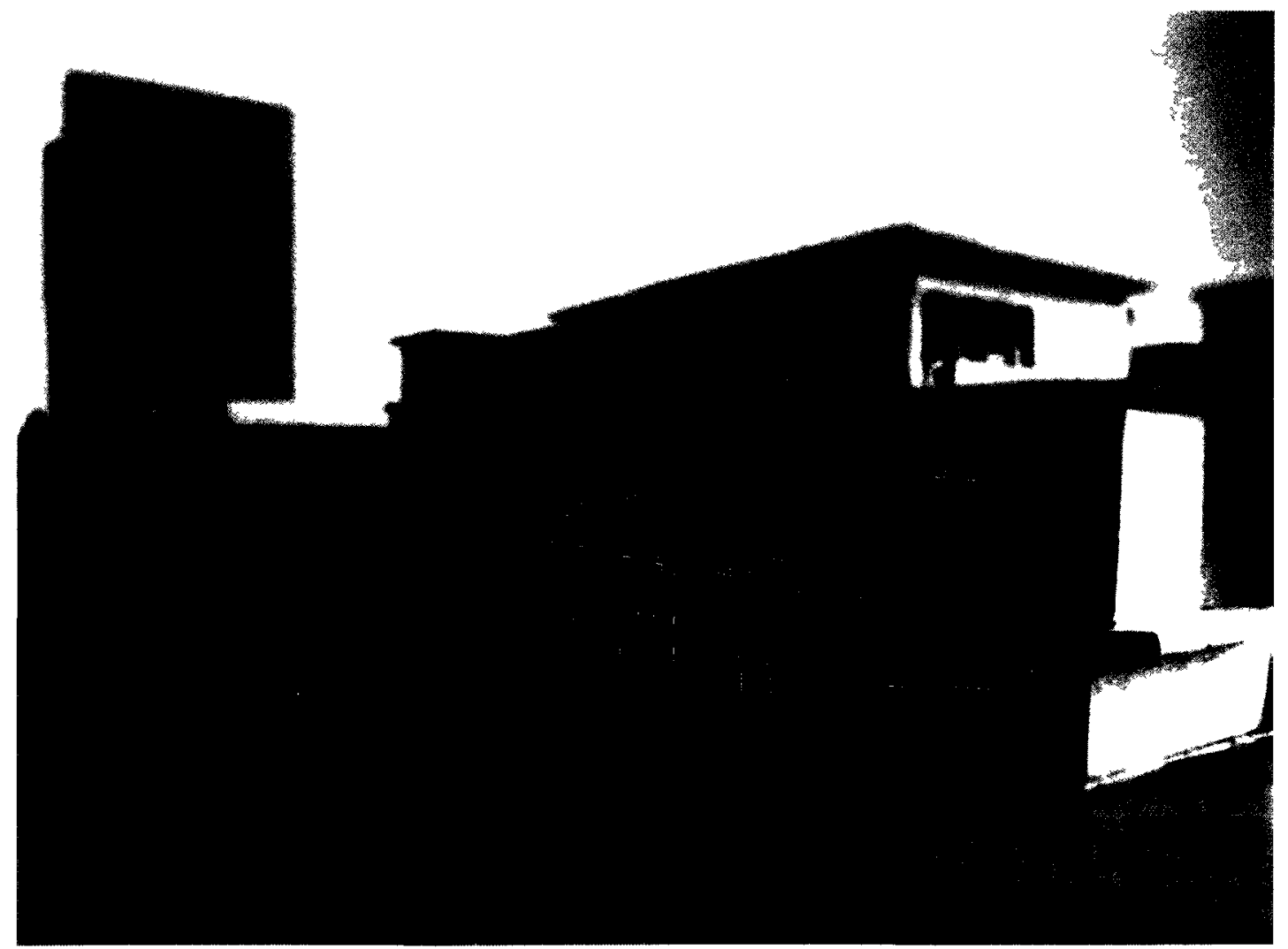

IIlustration 66 Commercial building with artists /ive/work studios, and gallery spaces 


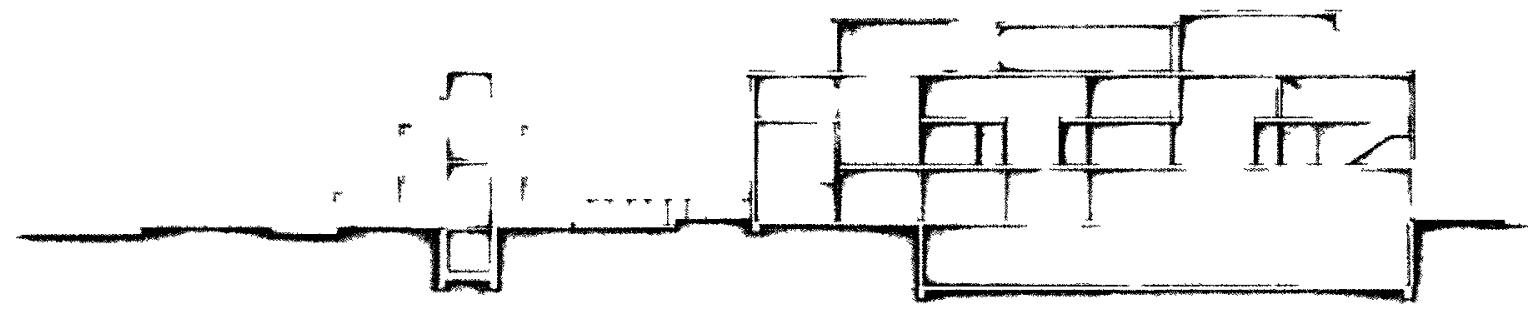

Illustration 67 Section though commercial space, gallery, and resıdences Public gallery spaces are shaded for clarity

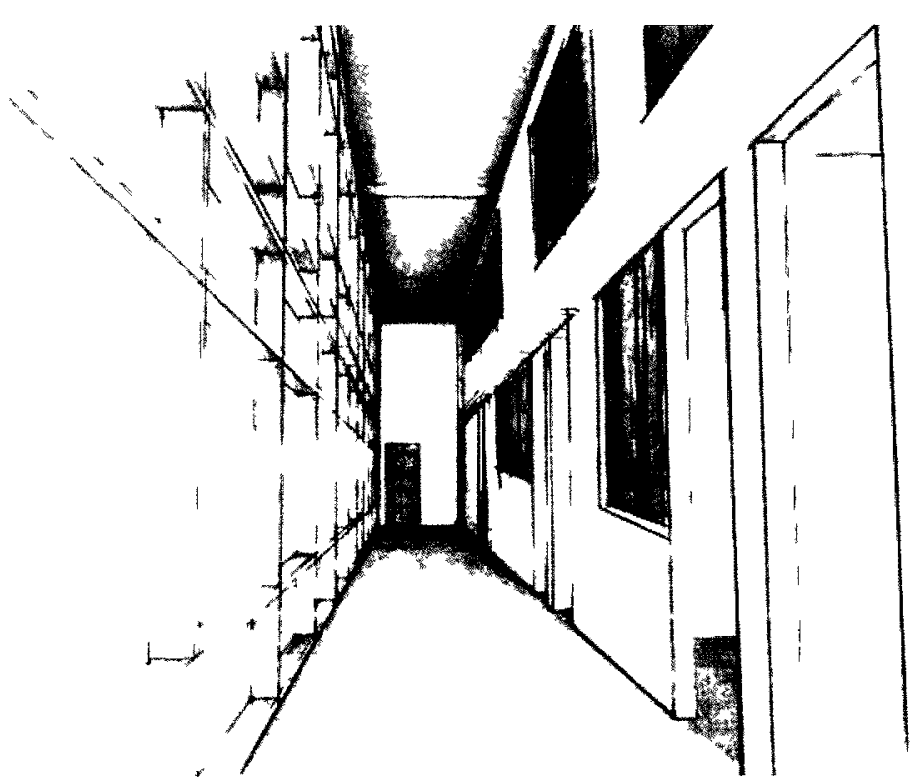

Illustration 68 Interior double height corridor leading to exterior gallery space artıst studios, and residences 


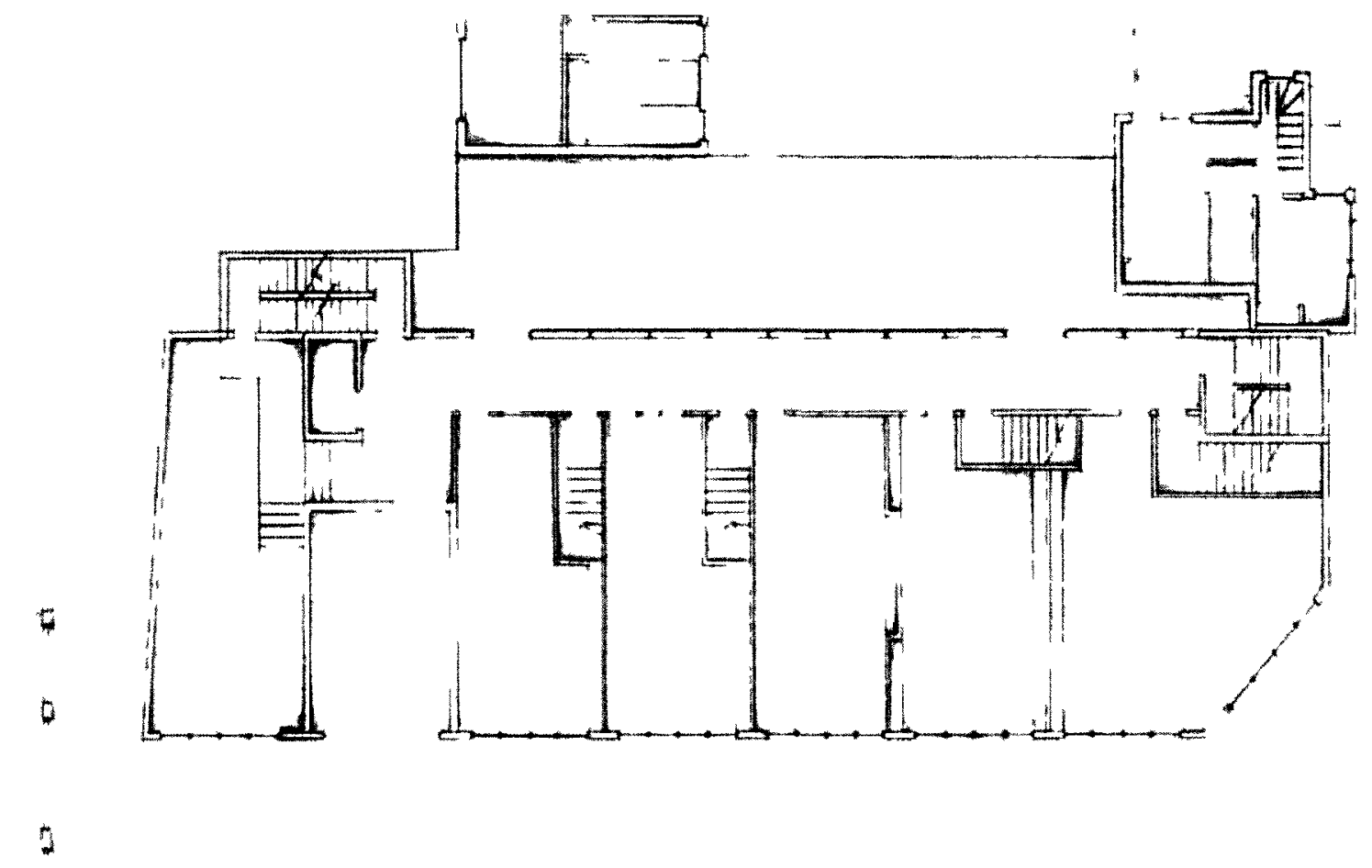

IIIustration 69 Second floor of commercial building, showing terraces, studios, and entrance stairs to residences

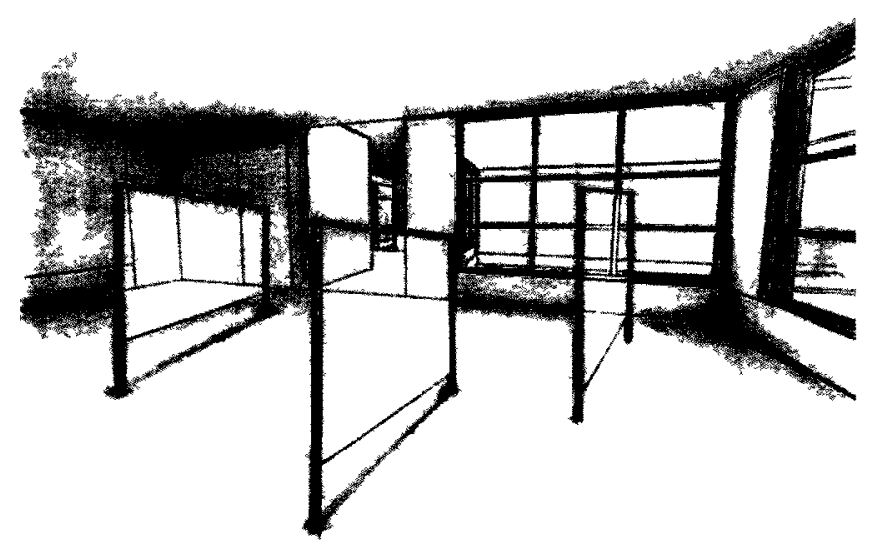

Illustration 70 Third floor gallery space perspective sketch 


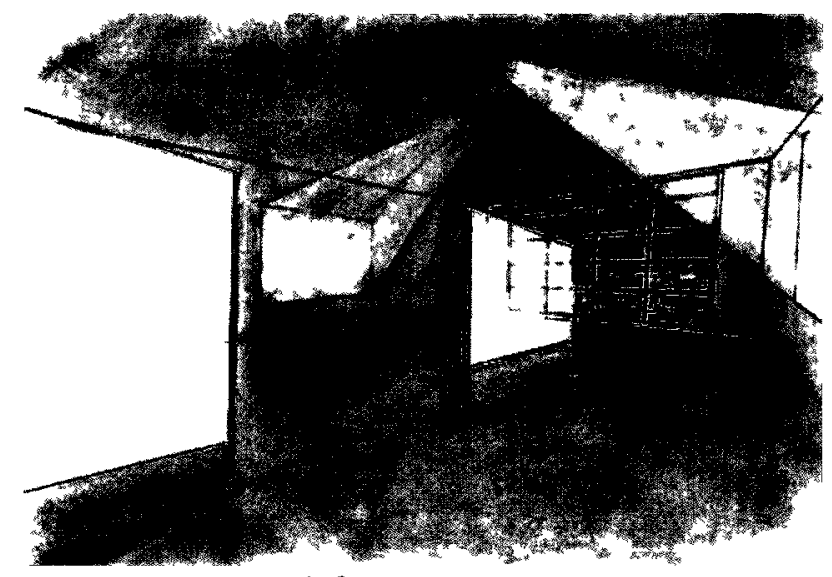

Illustration 71 Fourth floor gallery space perspective sketch, at night

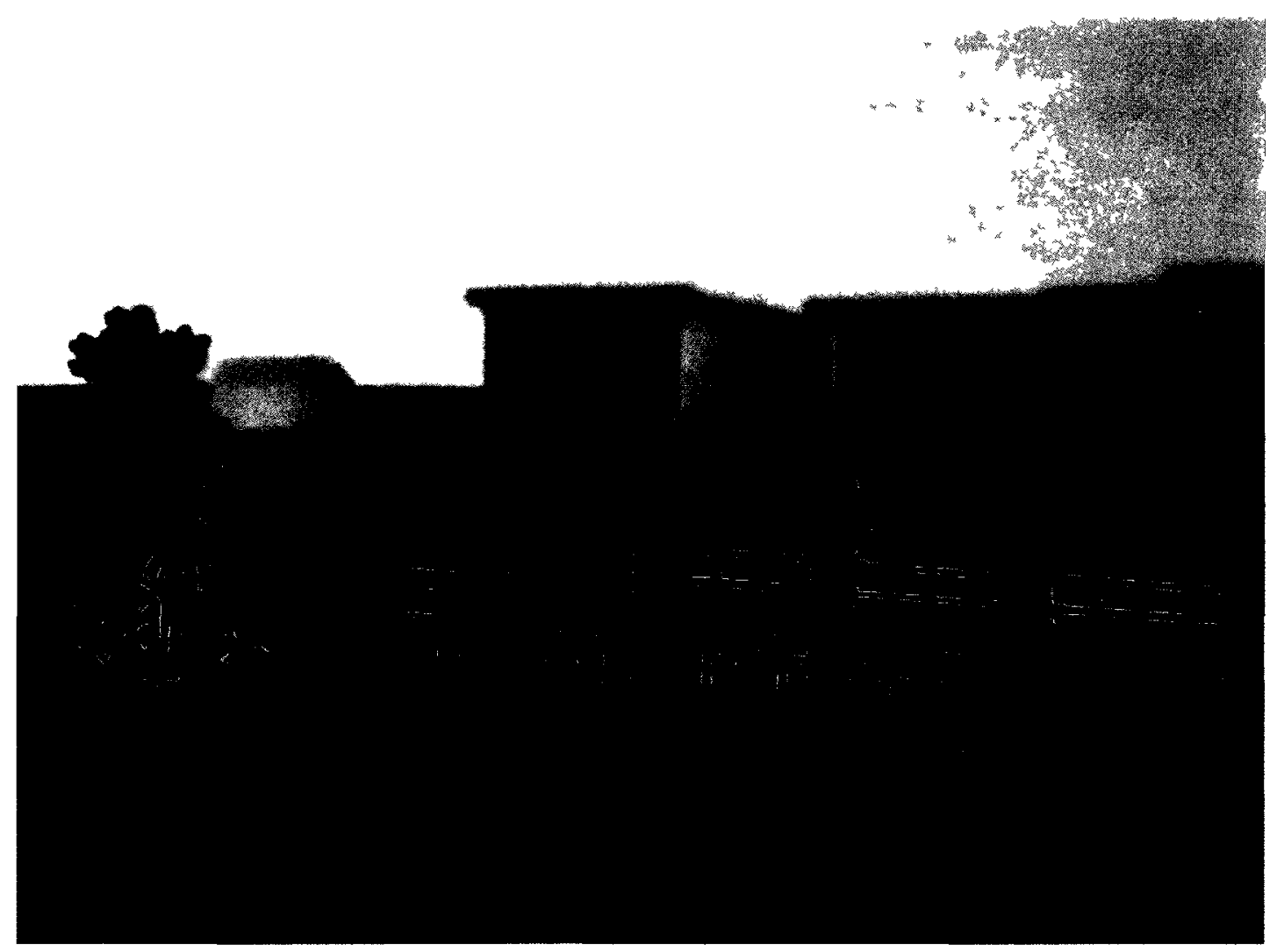

Illustration 72 Though not at night, the main entrance, and gallery spaces are assembled in a column on the left side of the commercial building, lighting up at night 

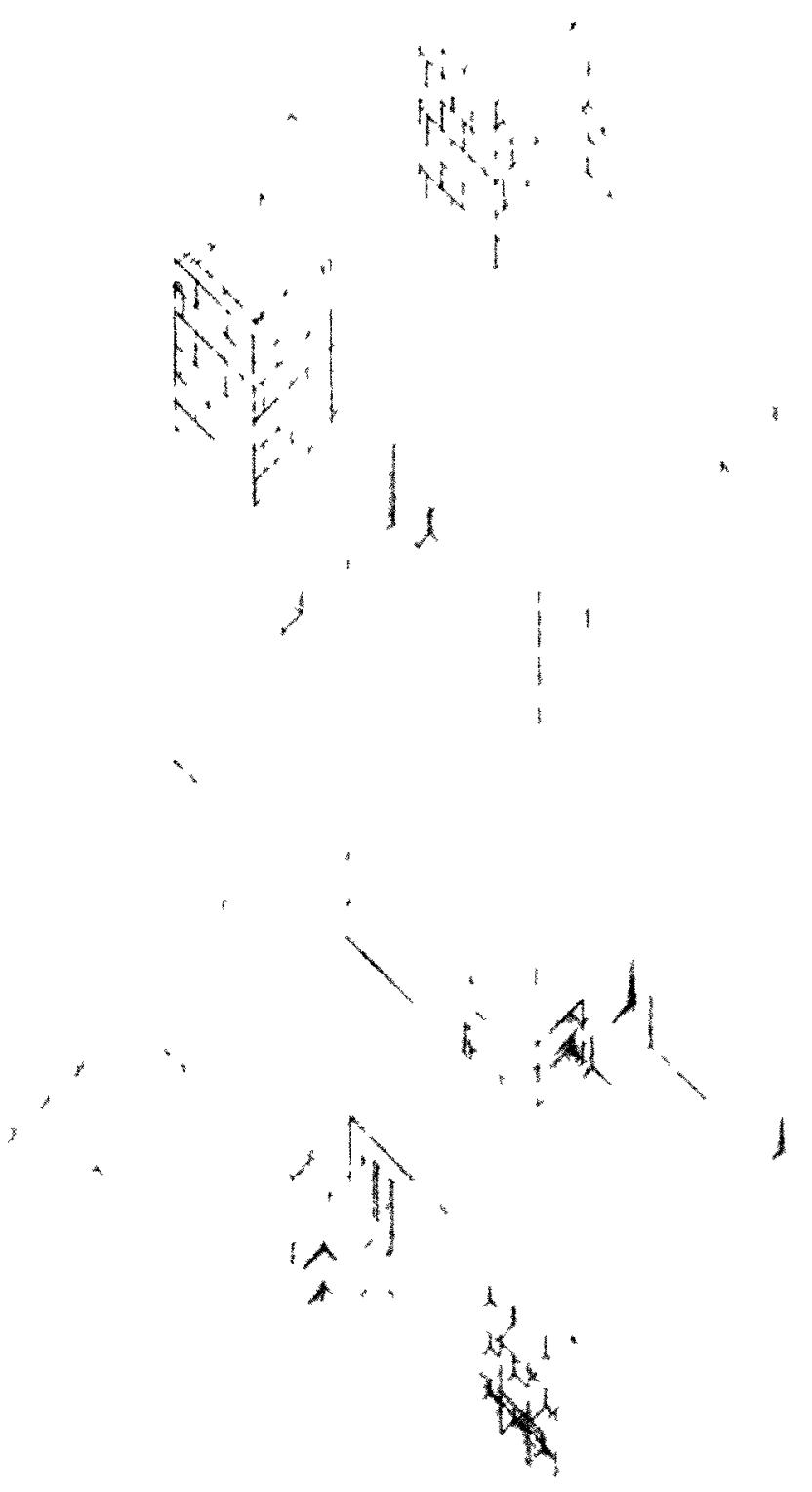

IIIustratıon 73 Axonometric of an Artısts /ive/work studio 


\section{Residential}

The residential portion of the site incorporates 15 different units in a single building. Unlike a condominium, or apartment building, this building is designed through the personalization of each unit. For each unit to have character, the first step is the personalize each to the first inhabitant. After the main exterior walls were decided for each individual unit, they were assembled in an arrangement that would both fit the position of the rooms, and which floor that was best suited for that inhabitant. While, each unit did not fit perfectly with each other, a play between the units become necessary, pushing and pulling, creating a cohesive whole. With each push and pull of the space, a relationship between the individual forms begin to frame exterior spaces, and create additional nooks and niches on the interior (III. 74-76).

Within each unit, materiality, arrangement, form, and lighting are used in different ways to create spaces that not only provide hooks and triggers for memories, but creating spaces that compliment the inhabitant. Split levels are used in some units to create definition within the house, provide nooks for retreating to, while allowing a connection through the space (III. 77). Adding additional thickness to a wall is another way to enhances a space. Built in shelving, and cubbyholes in the walls, not only reduces the need to extra furnishings, but creates display cases for the inhabitants items (III. 77). The same wall detail may be used to store everyday objects, memorabilia, mementos, or helps the inhabitant with an activity they enjoy 
the most. Though similar details may be used in different units, it is the user that determines how it is used, and therefore a discourse of how it is used, and interacted with is created.

Similarly, with an open plan, the user determines its use, but unlike the wall details, an open plan does not offer any discourse. It does not add to or accentuate any use that is applied to it, but rather is just there. Many models houses include the open concept plan on the ground floor, especially as the spaces become smaller. In this design, only some units have open plans, when it works for the inhabitant, while others incorporate a more traditional separation of rooms. In some cases, a moveable wall between rooms is utilized, for example, between the dining room and family room. Therefore the moveable wall can be open when only the family is home, or closed when there are guests, or when two different activities require separate rooms and privacy. The following section will go through 3 units within the complex. See appendix $A$ for the rest of the floor plans showing all units in the residential complex.

The first example is shown in Illustration 78. This unit is designed for an older family, whose two children are away at school and only come home for the summers. Located on the second floor of the complex, there is no ground exterior space, but instead a patio overlooking the courtyard and artists terrace. The main floor includes a niche for the mother who enjoys playing the piano, a kitchen, dining room, living room, and small bedroom. Though the plan is mostly open, the kitchen and eating area are separated from the living space with an extended wall, and half wall. The half wall also has shelves for display which further separate the dining 
room and living room. Around the corner from the living space, is a niche made for a piano, and the door to the outdoor patio. This niche could be used for other activities of futures owners, giving them a space where they can retreat to do their favourite hobby, while still being a part of the rest of the room. The bedroom on the lower level, is tucked under the stairs, though small, it works well for guests, and visiting family. This space is also great for small children. The smallness of the space is proportional to a child, and alludes to the idea of a fort, and daydreaming.

Upstairs, there are 2 bedrooms and a cozy sitting area. Though the children are away most of the year, this area is a place where awards, photos, and personal collections are displayed. The built in couch has storage underneath, as well as acts as a quite place for reading, or having conversations.

The living room, and activity niche space is double height, while the kitchen and dining area have lower ceilings for a more intimate feel. Also, the two floors of the unit are not situated on top of each other, allowing for a long view up into the bedroom area, and alluding to spaciousness. Lighting into these areas also compliment the program of the room. In the kitchen, a long high window is used to provide light, but still allow for counter space below, while in the dining room, four smaller windows are used. The windows in the living room provide lots of light, while still allowing for wall space for personal photographs or a television. Upstairs, in the master bedroom, because of an over thick wall with shelving in it, there is a window that is very deep creating another nook for reading or contemplation.

Illustration 79 shows a smaller unit, designed for a couple just starting out. This 
couple likes to entertain a lot, so the main part of their unit is designed to accommodate guests and entertaining. The design begins with the unit being located on the ground floor, which allows the occupants to have their own private entrance to their house. Entering the unit, guest descend from the foyer into the kitchen, living room, and dining room. Only the hallway leading into the bedroom and bathroom are at the same level as the entrance, causing one to definitively feel as though they had entered into a separate area without completely separating the spaces. The dining room, though in the area of the house which is lowered, is visually separated from the rest of the of the house with the use of a lowered beam, and a single step up. This makes the space very intimate. Though there is no natural lighting in the dining area, dimmable pot lights within the lowered beam and around the room control the lighting atmosphere. Built in shelving within the dining area provide a place for dishes to be displayed, while leaving them easy to put away and bring out. The living room is open concept, to hold a large party, but is also cut off from the kitchen on one side to allow a secluded space that could be turned into a guest room at the end of the night. A hobby room is located beside the living area so that it is close to the main room, but has the ability to be closed off when guests arrive. The bedroom is extra large so if one did need to retreat to a quite place, a sitting room within the bedroom could be utilized. Inside the bedroom, a unique block wall indicating the location of the elevator behind it, begins to separate the bedroom and sitting area, providing not only a place to retreat to, but also a quiet place for reading.

Lastly, Illustration 80 is a unit designed for a single person, an editor and avid book collector and reader. Though most of the amenities for this unit are located on the 
lower level of this unit, (the kitchen, bathroom, and bedroom) the main living space is located in the loft above. Working from home, the loft space provides a distinct space that is differentiated from the normal house amenities, making the space easier to work in, having less distractions, and providing a secluded spot to enjoy reading. Lighting also helps delineate these two spaces, with brighter, more intense light on the lower level, and only soft, subtle light entering the upstairs by either small high windows, or the filtering of light coming up from the double height space. Built in shelving following the stairs up to the second level also to allude to a different space. The book shelf rises up to form the only partition upstairs, creating a very strong formal element within the small house. The built in shelving is adjustable, to accommodate any type of book, or be rearranged to fit other things such as a television, or other media devises. The shelving also extends into a long table to spread out papers or work. The upper level also has access to a small outdoor area.

While each of the units are different, a character can be found in each through the personalization of the unit. The personalization facilitates each individual with everyday tasks, and hobbies, making it more comfortable, and equally creating a discourse with the architecture. Through the uniqueness of each unit, hooks are created which memories can hold on to and become more remarkable. The hooks can also be triggers from past experiences. Perhaps a raised dining room, a shelf acting as a room divider, or even a built in seating area can trigger past experiences of your own life. Even after the original owners, the new owners are able to interact with the character that has formed. A raised dining room may become a play room for a child, or the shelving that followed the stairs may become a showcase for 
valuables collected on trips from around the world. Whomever moves in, they chose the house because it has a character which seems to be in tune with them. This give and take, letting the architecture inform you, and you inform the architecture, creates an interaction and discourse and life within the house. 


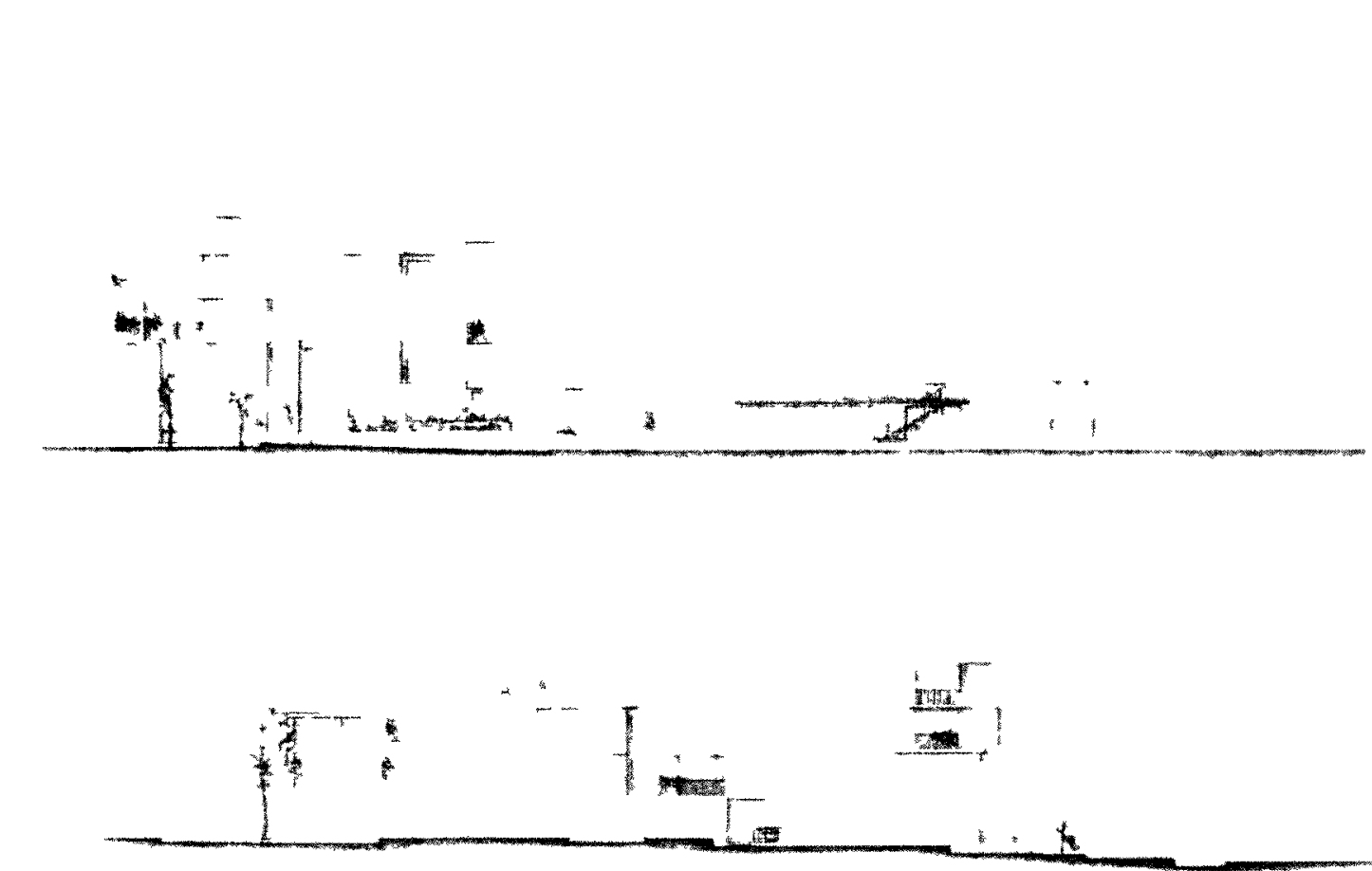

IIIustration 74 Top - Grant Street (North) elevation, bottom - East elevation

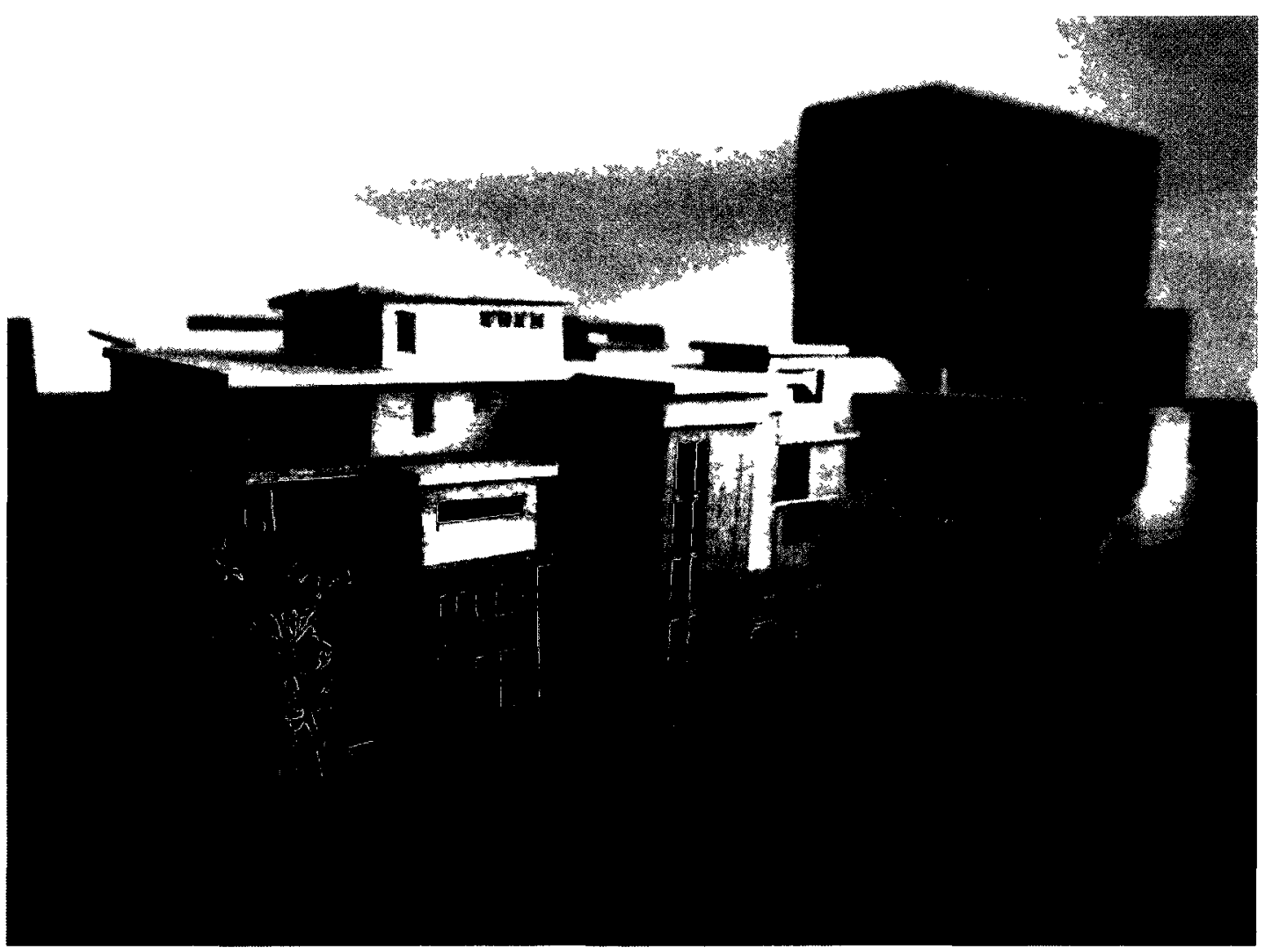

Illustration 75 Bass wood model, showing north east corner of site 


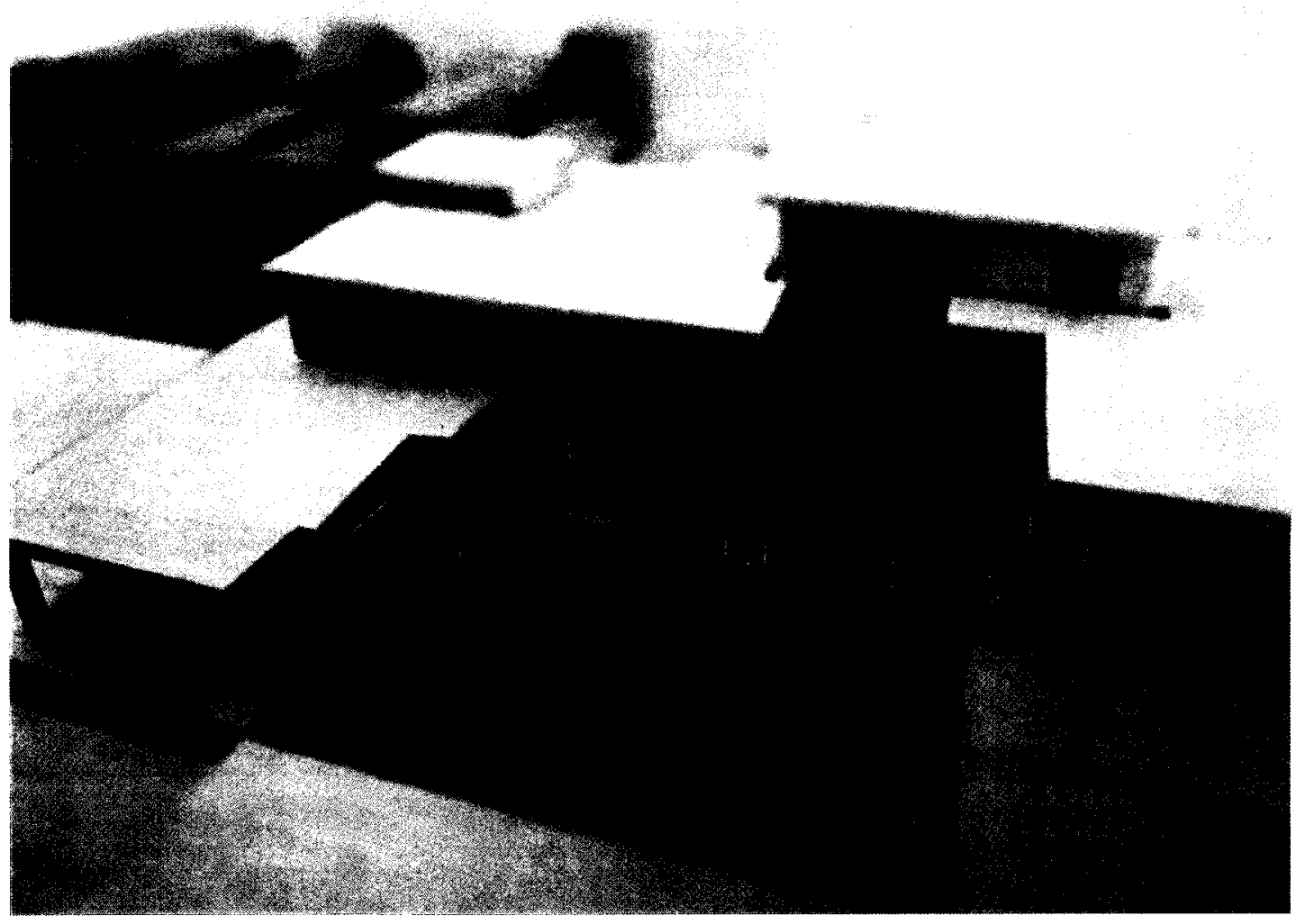

IIlustration 76: Bass wood model, view into interior courtyard of residential complex

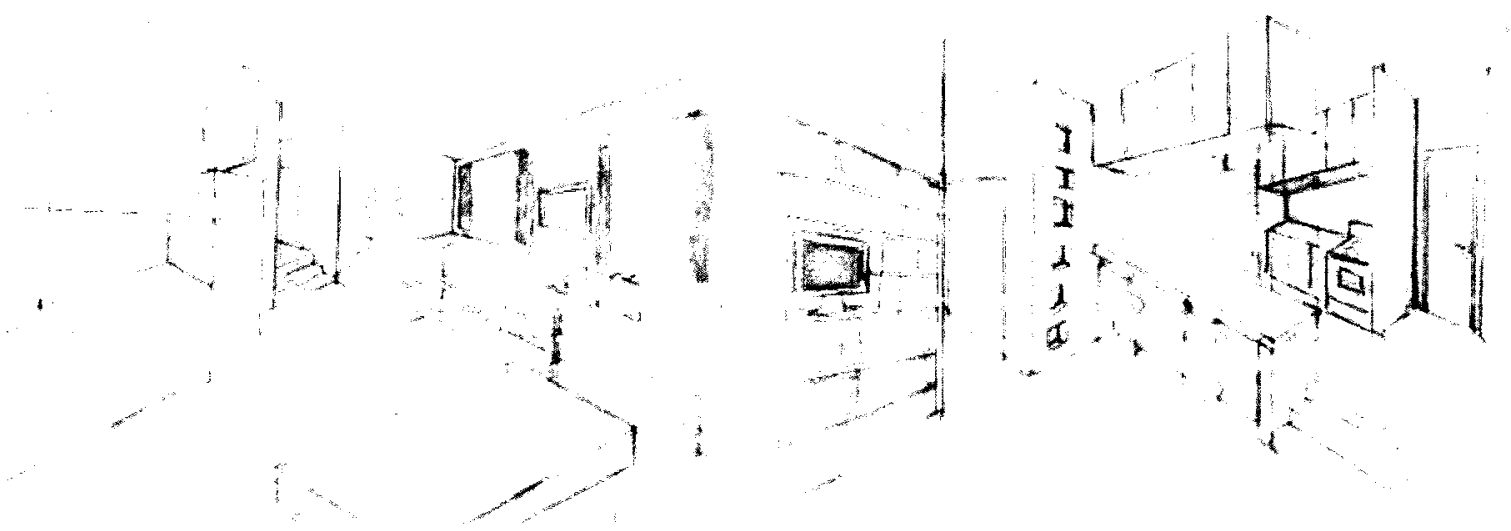

Illustration 77: Sketch examples of the use of split levels 


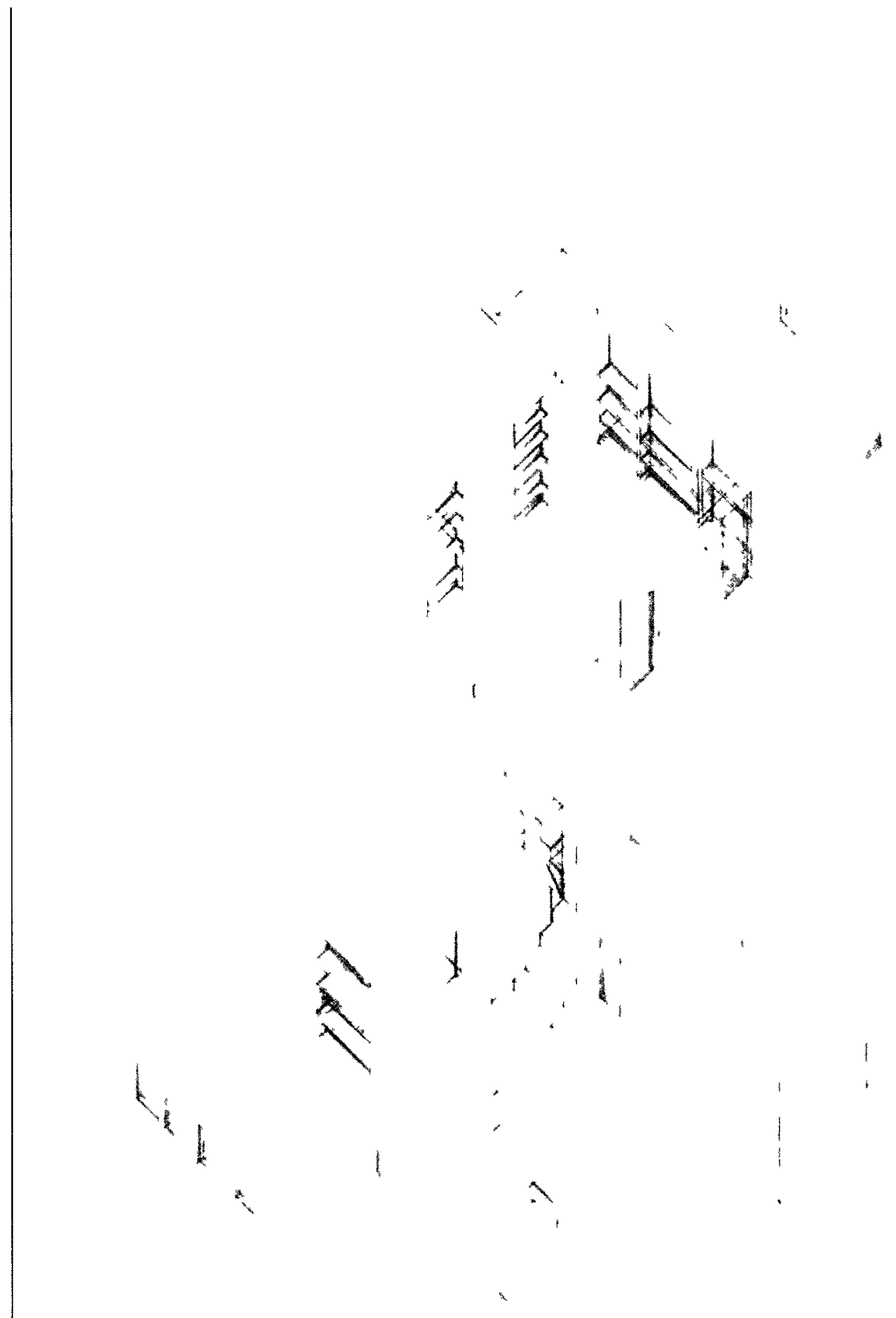

IIIustration 78 Example unit 1 , 


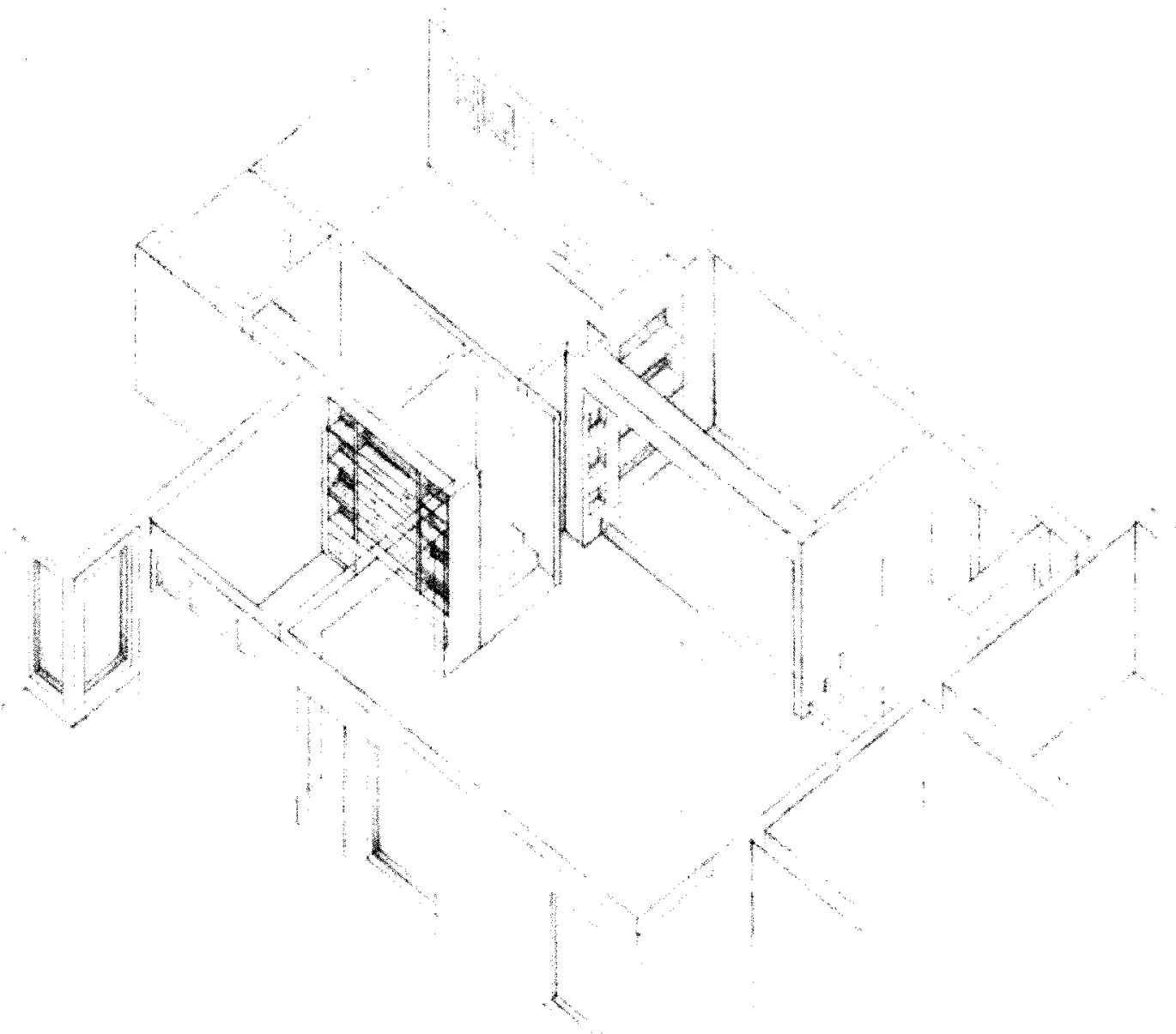



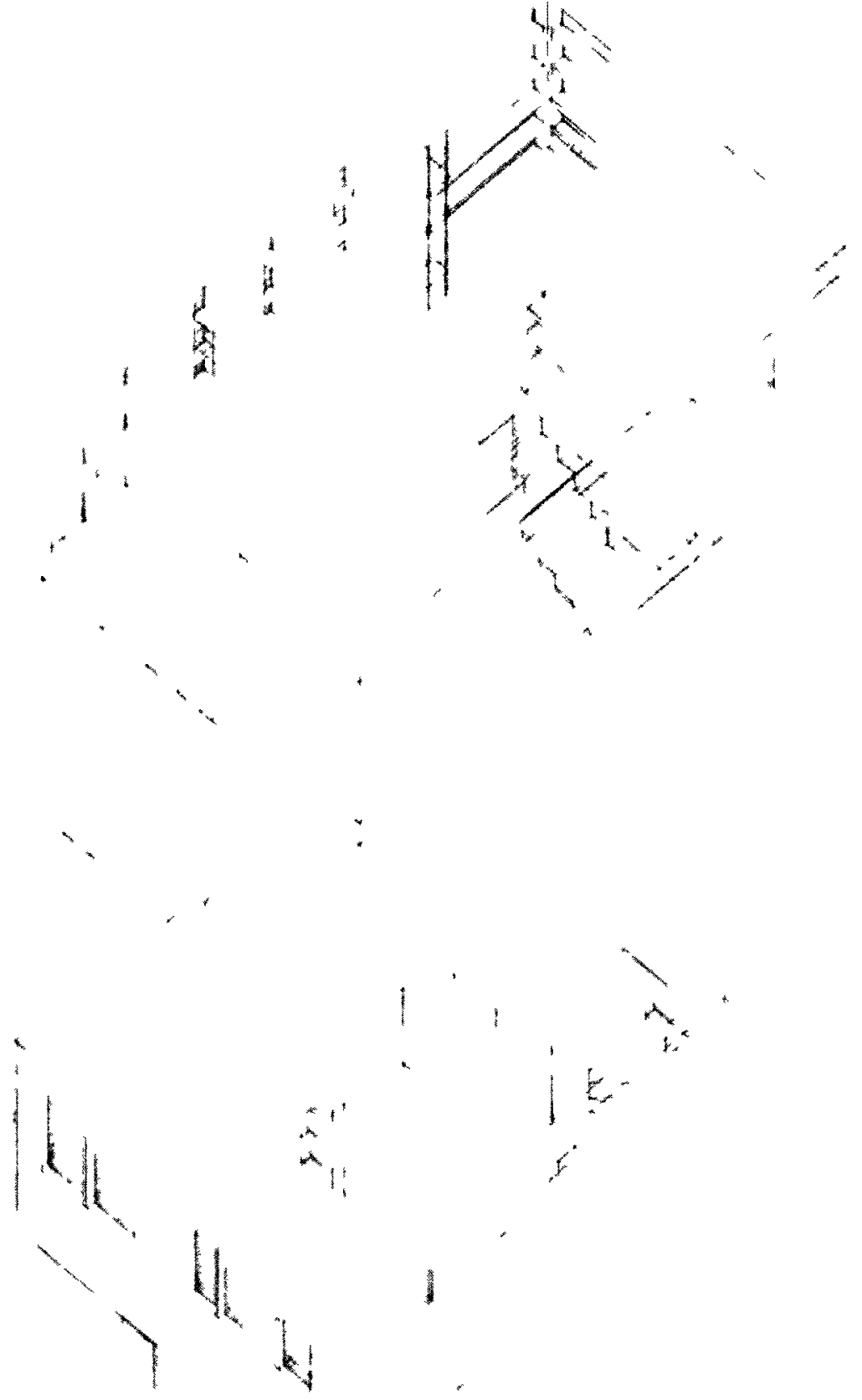

Illustration 80 Example unit 3 


\section{Conclusion}

As a dreaming place, relaxing place, and place of solitude, the house is required to be more than just shelter, it needs to live with us, and become our own world.

Metaphors and Space proposes that the life within a house can be explained as the space metaphors created and experienced within, and the interaction that one has with the house.

Interaction between the house and the inhabitant is generated by the character of the house which is established through form, materiality, assemblage, and light. These create the niches and nooks, the light and the shadow, and the smooth and textured spaces which allow for unique interactions with the house. It is through these acts that one remembers their first house, and has the ability to relive those moments. Without these characteristics in the house, memories do not have hooks to hold on to, and can be lost in our vast range of our experiences. These memories can later be re-experienced when the relevant trigger is presented, creating a space-metaphor. The space-metaphor enhances the spatial experience in the house; the past space from a memory is imposed on the present space, creating a new perceptive view of 
the space being currently inhabited.

The quality, or intensity, of character, can be implemented in every new house, but few show these characters. New houses are thought of as a facility for memory making, or daydreaming, rather than what they should be, a space that nurtures, provokes, and accentuates memories. The first house one experiences has important memories associated with it, but it is the current house one lives in that trigger these memories. In the suburban and urban analysis, little or no triggers are evident, the spaces are made for memories to happen in, rather than being made with them. Blank walls, and square rooms, though allowing for anything to happen in the space, fade into the background. Furniture delineates spaces in these houses, therefore requiring more pieces of furniture, and therefore more space.

Using, and understanding the analysis, the proposed design utilizes characteristics to enrich the experiences within the house, and create a discourse which bring further appreciation to the house. Using built in shelving, multi-tiered or multi-leveled units, strong formal elements, views between rooms and elements, and personalization of the units, the house becomes more than just a shell. Rather than allowing the architecture to solely be another layer, the new design draws on the characteristics of the house to make it part of life, accentuating, and generating, life and memories. As our experiences are intensified within the house, not only are our memories clearer, but it provides a chance for them to be recalled, and therefore transferring their meaning to the new space. All of this generates a life within the house that would be left out, leaving the house an empty shell. 
The emphasis of bringing life into the house is key. When the inhabitant moves into a house for the first time, the architecture should speak to them about how it needs to be lived in, which starts a discourse. If more and more characteristics are present, the more the house is able to interact with its user, and the more ways in which the life is expressed. In this way the house always seems to have an action, or a thought, or give the inhabitant what they need in order to feel comfortable, safe, and secure. Just as the house interacts with its user, so too does it grow and live with them. The experiences and memories that are created within the house are strong, and a firm sense of belonging can be attained. When this quality in the house is met, the house is more than just a house, it becomes a home. 
Appendix A

Additıonal ımages of project

Drawings
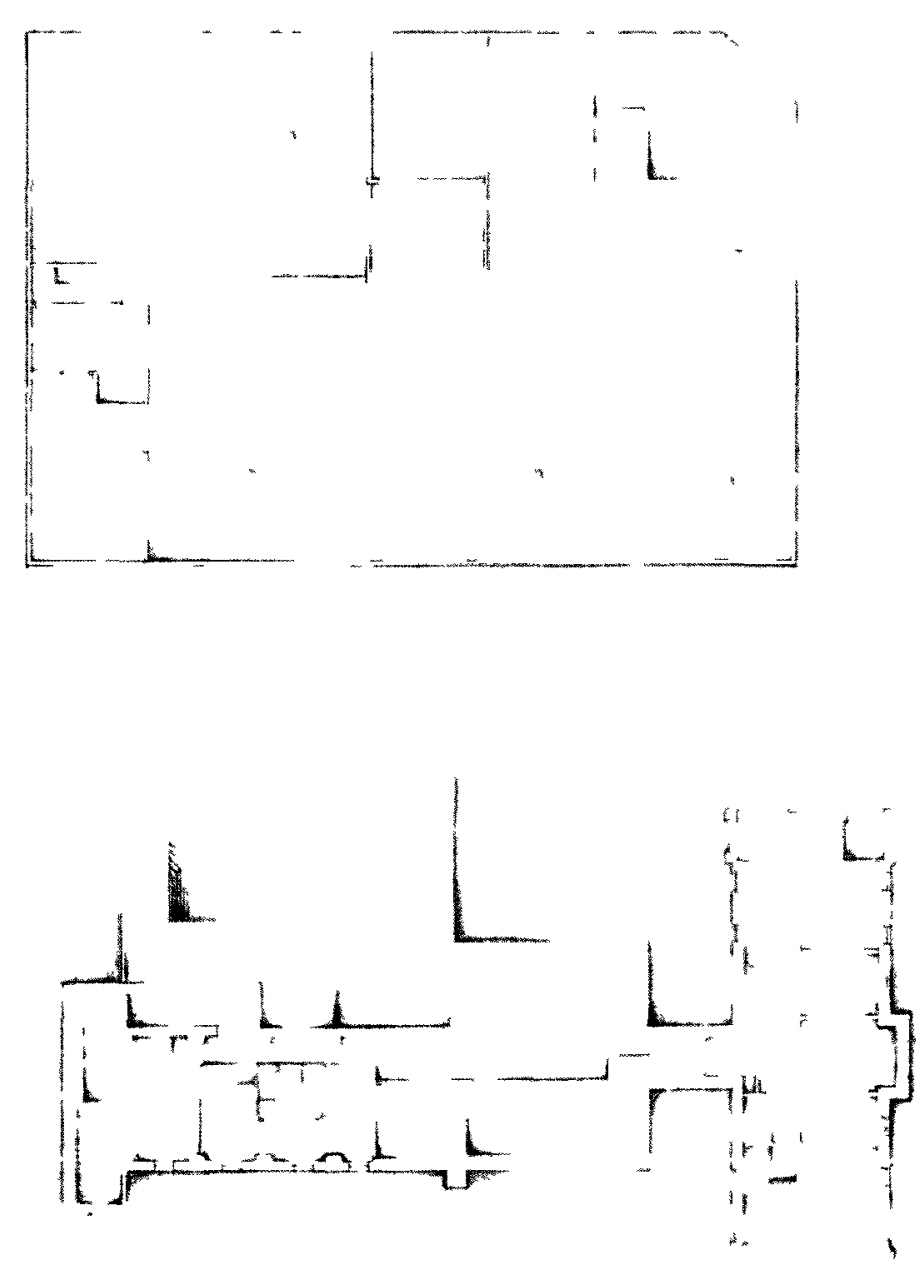


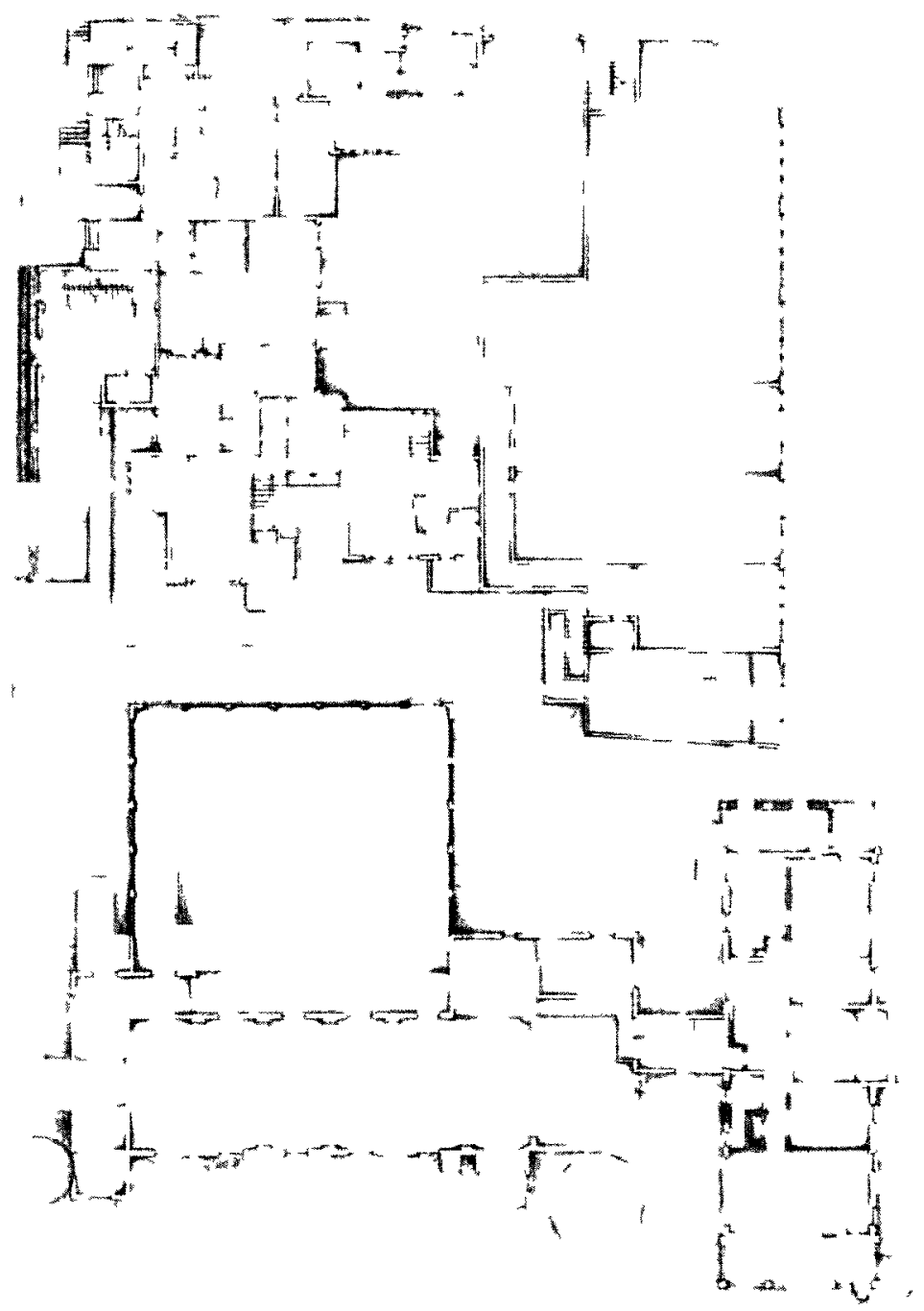




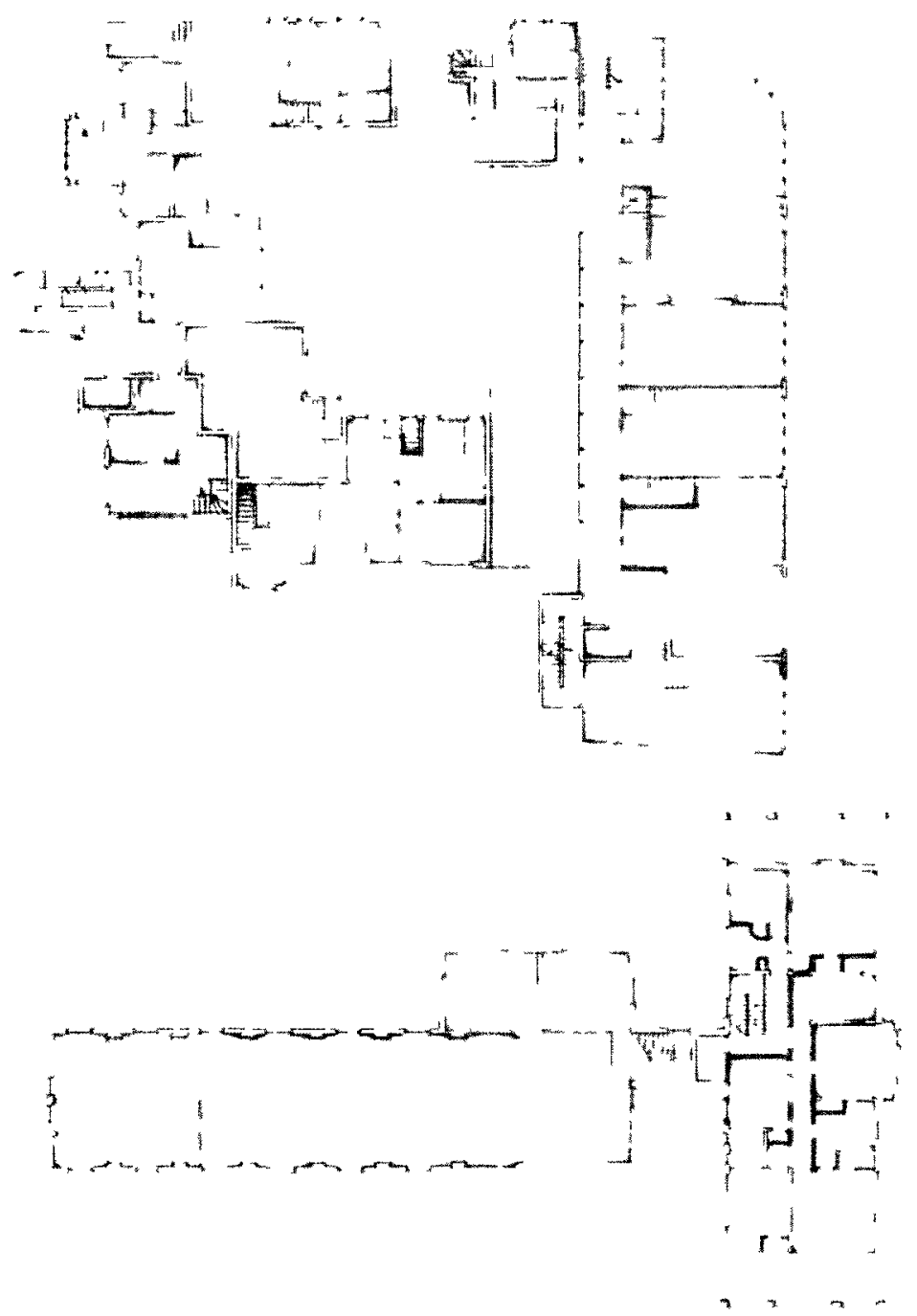




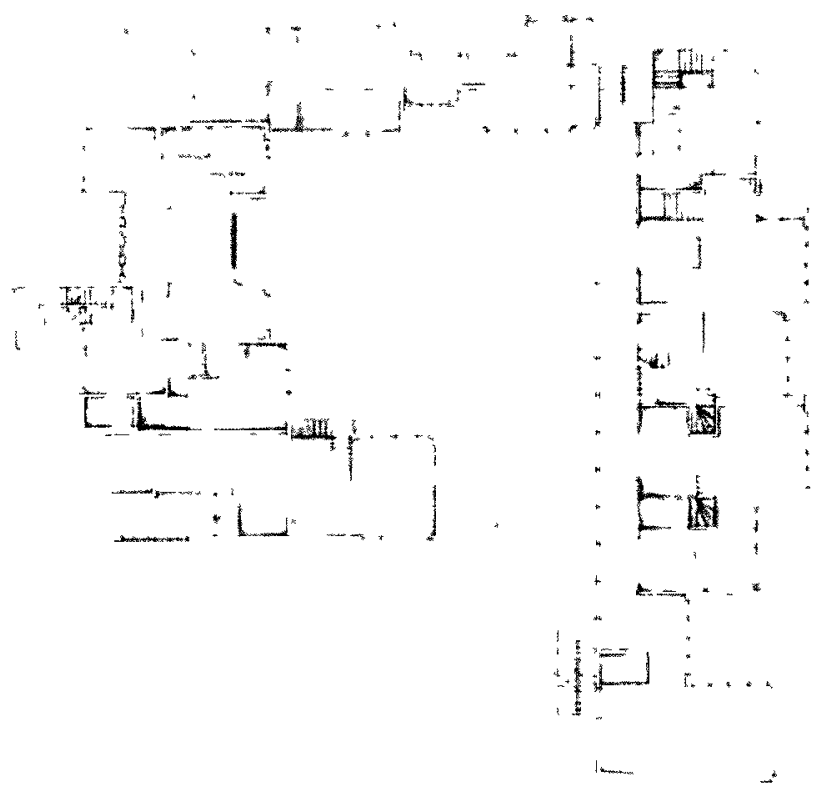



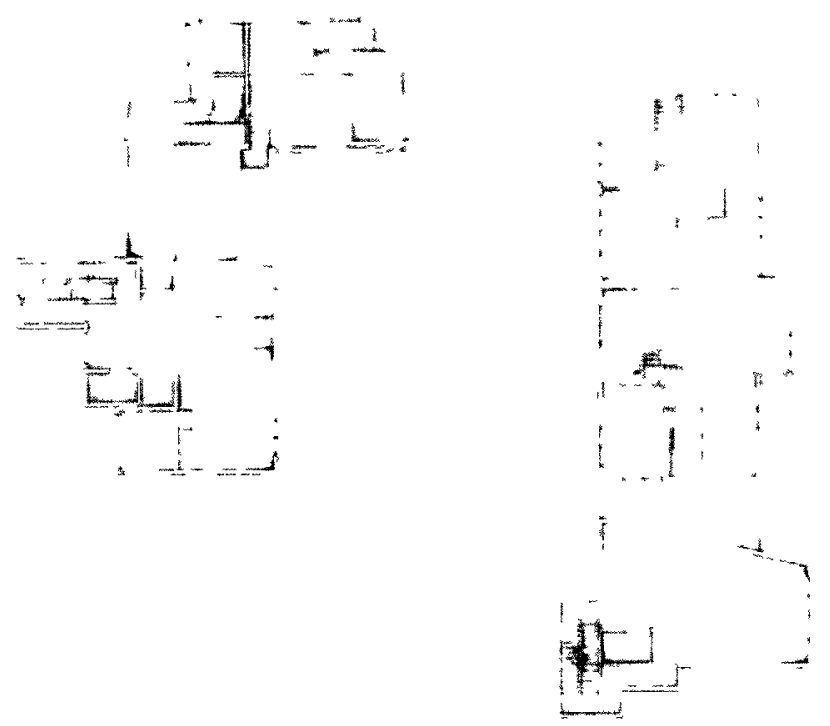


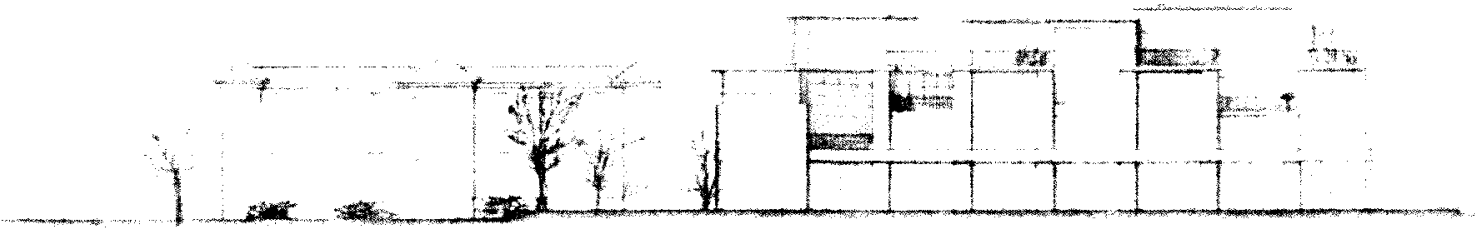

IIIustration 86: South and West elevations, North and East elevations on page 84

\section{Images of Model}

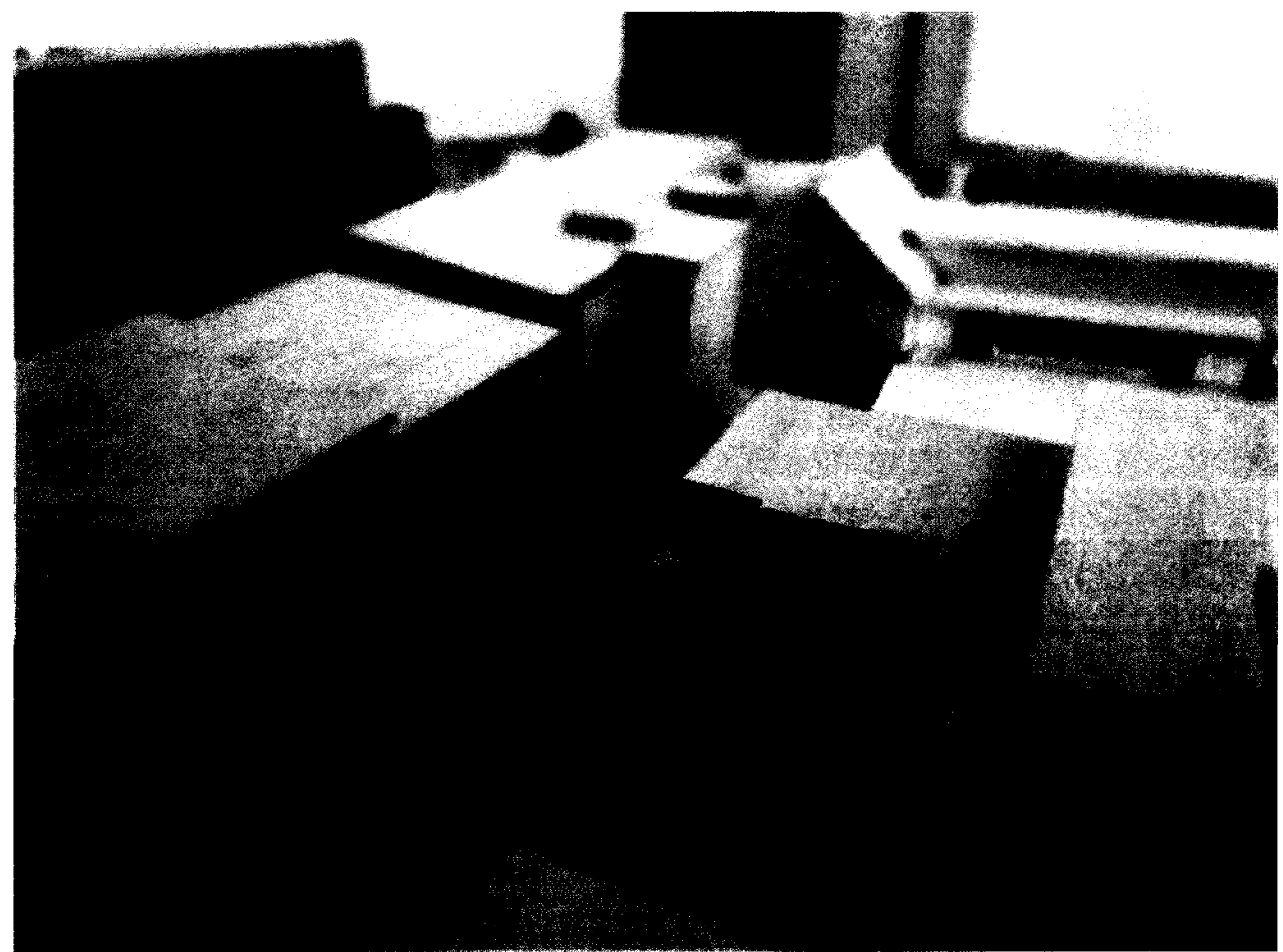

IIlustration 87: Back terrace between artist studios and residential complex 


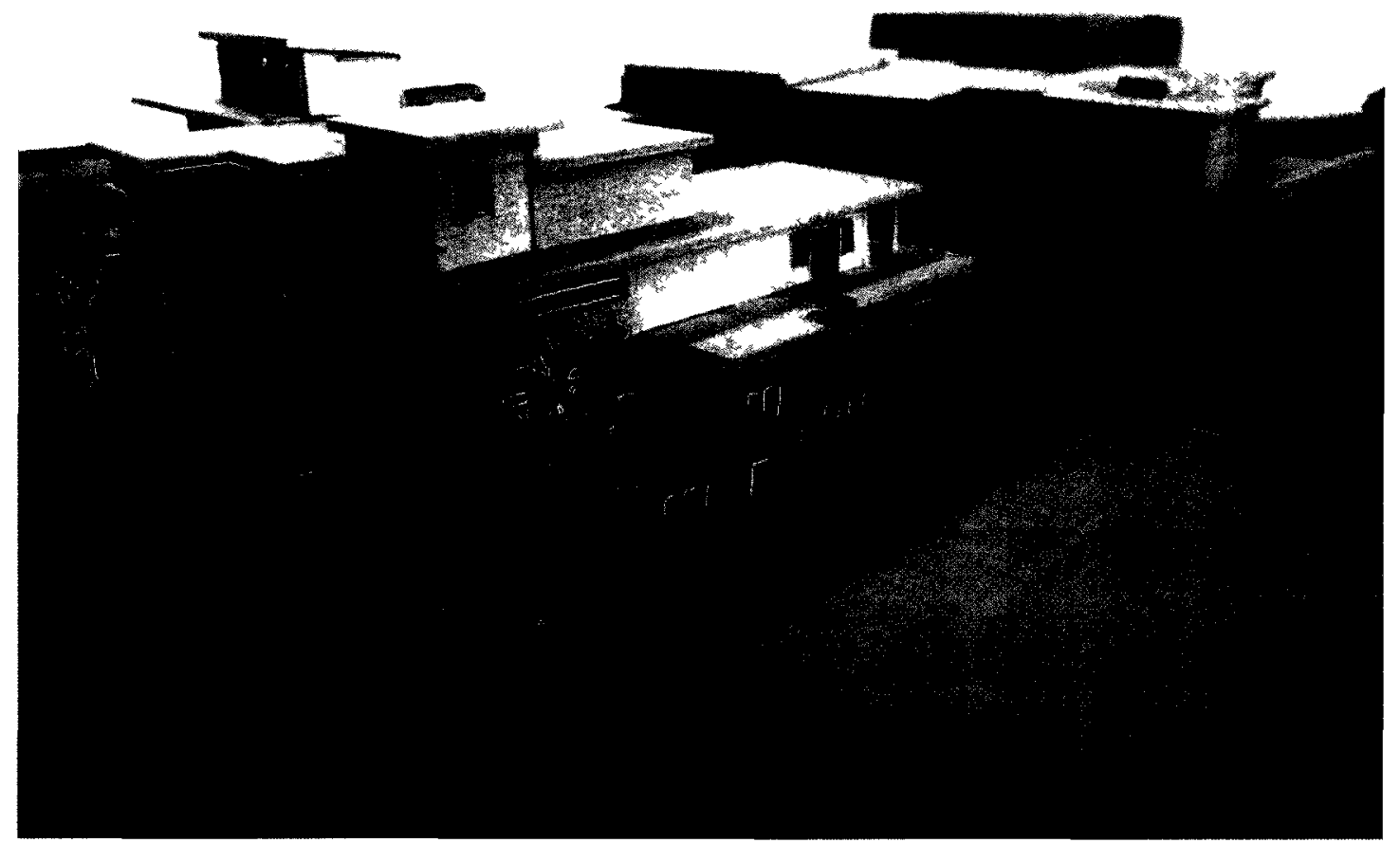

IIIustration 88 Front entrance, and East side of resıdential complex

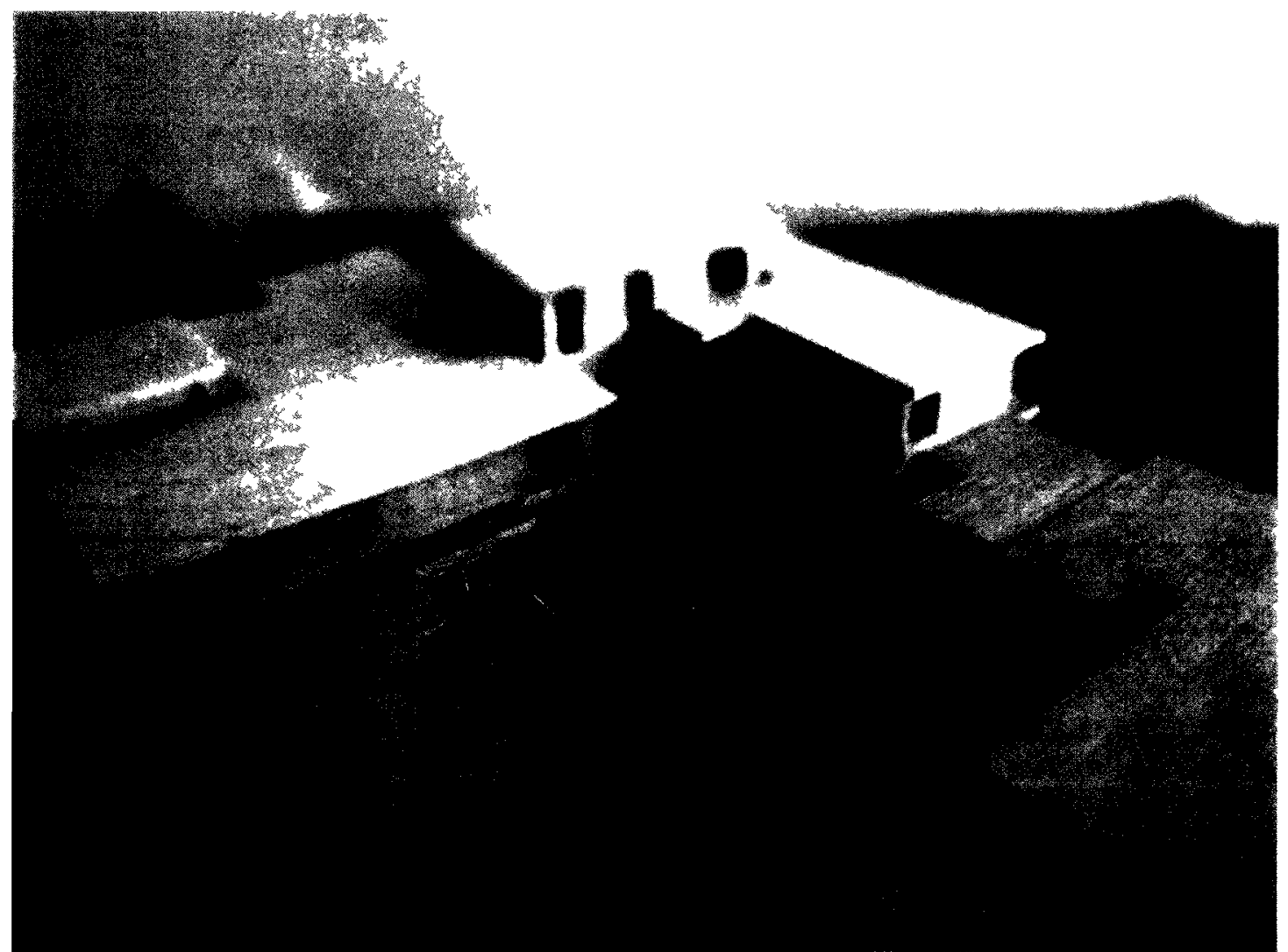

IIIustratıon 89 Interior courtyard 


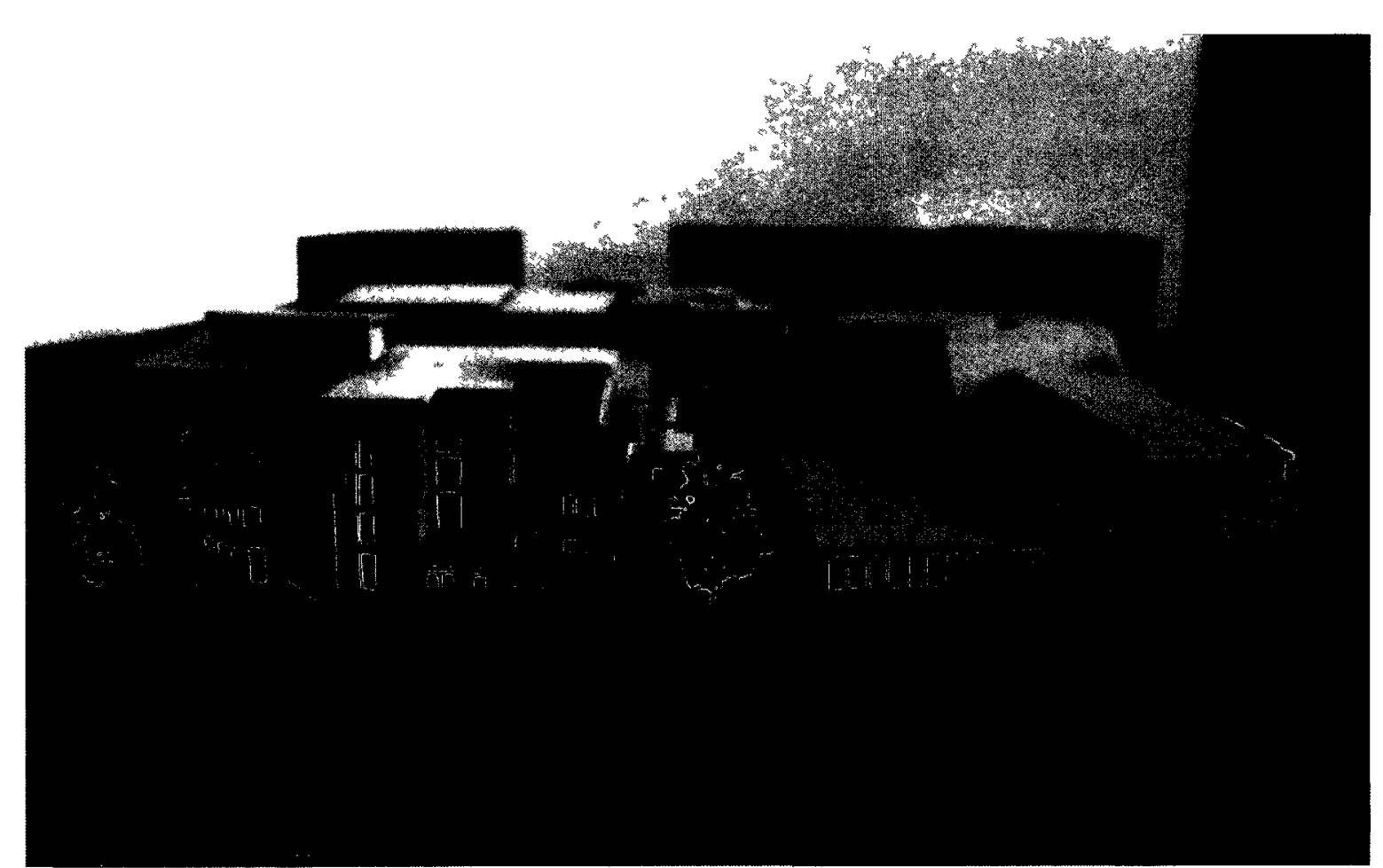

IIlustration 90 Grant Street view

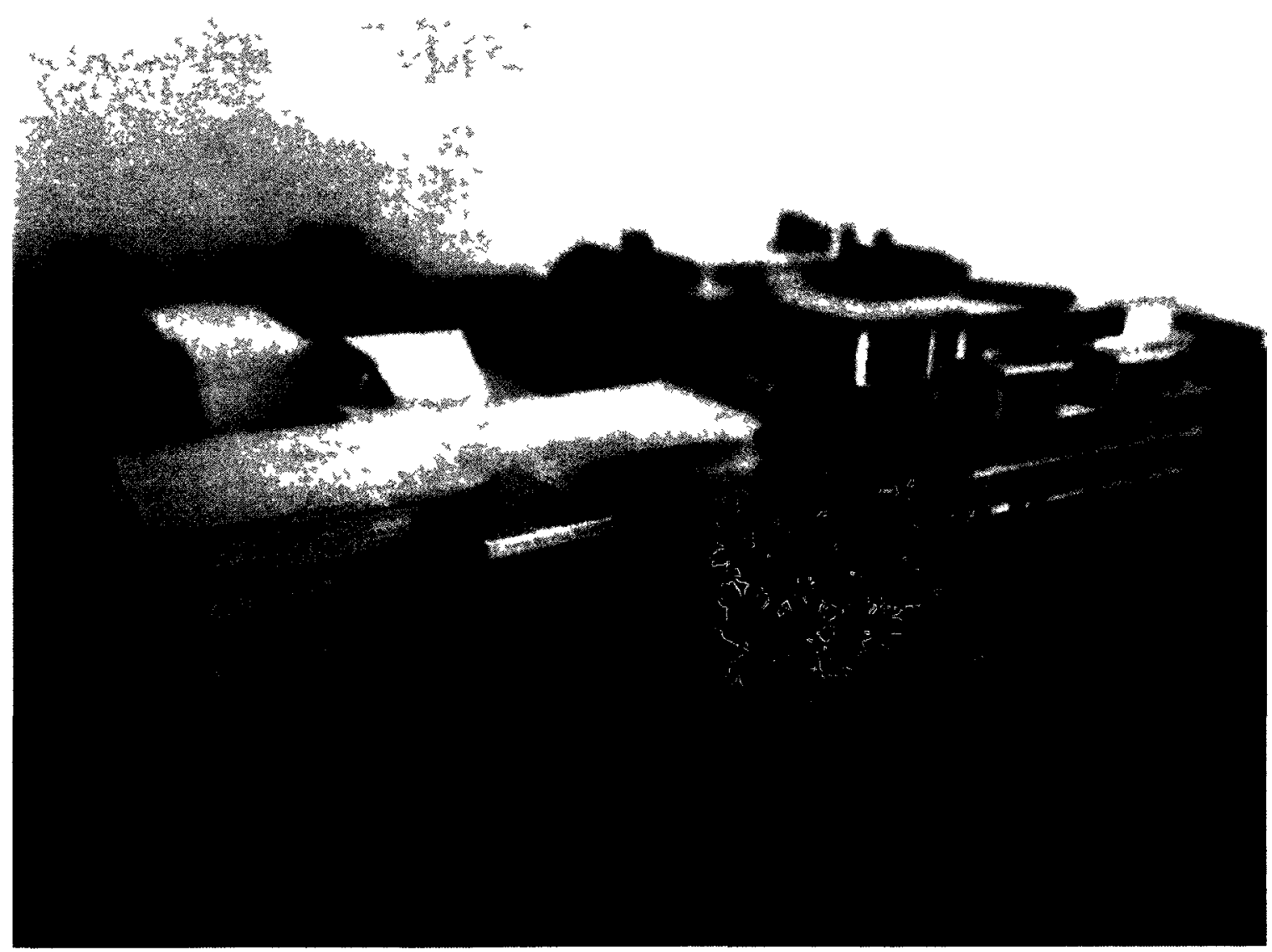

IIlustratıon 91 Bed and Breakfast (In exıstıng buildıng) 


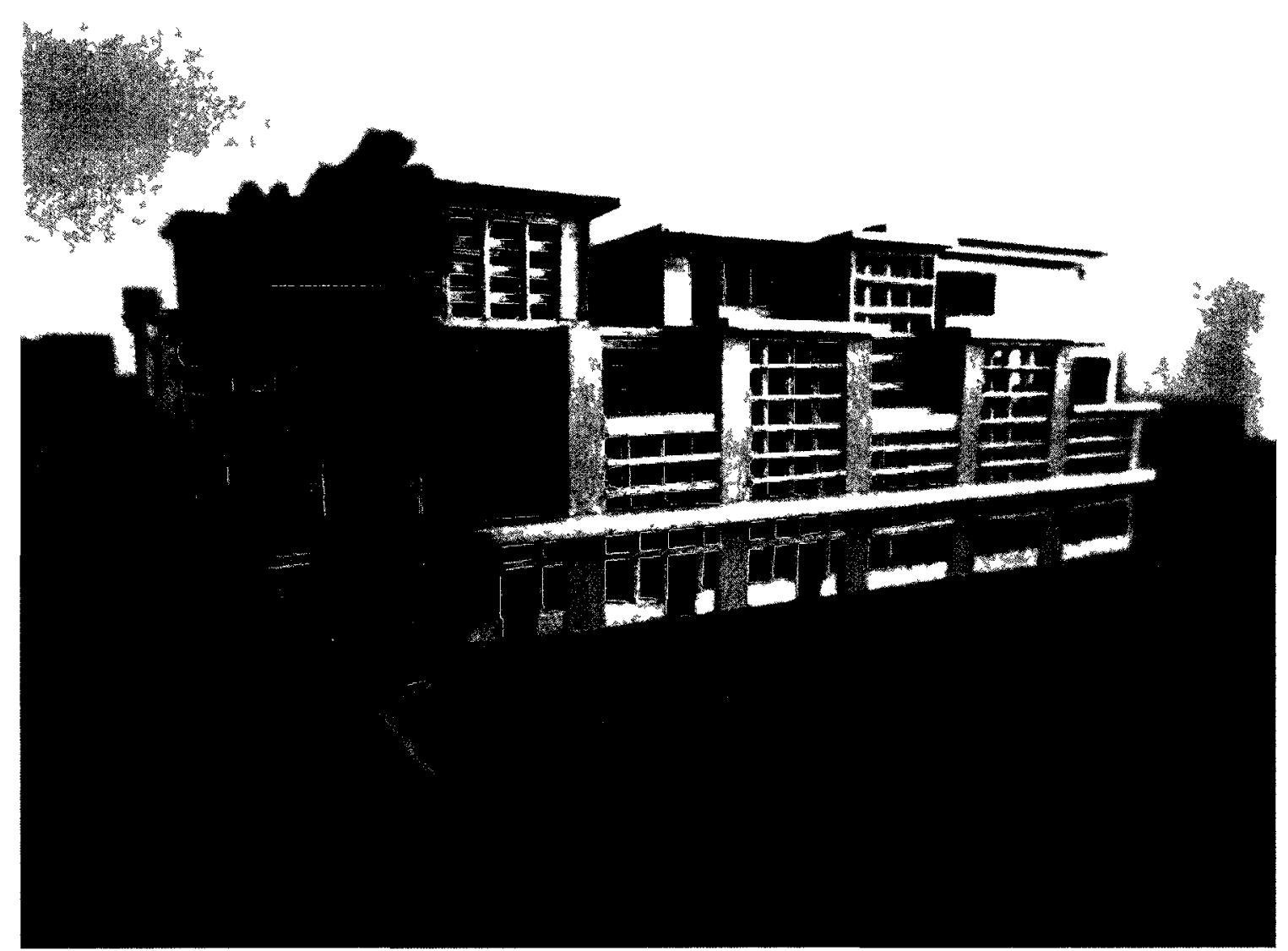

Illustration 92 Commercial bullding

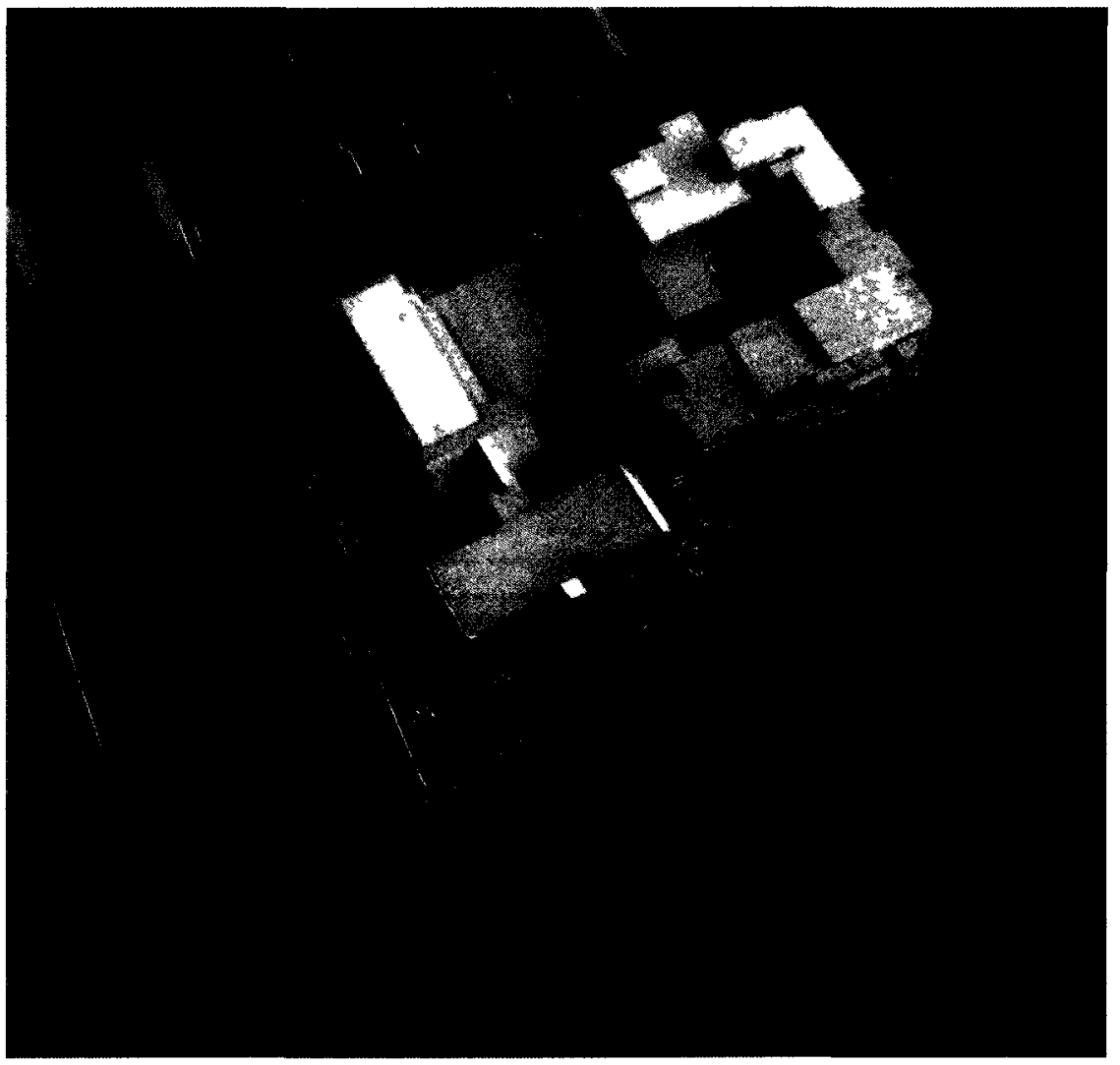




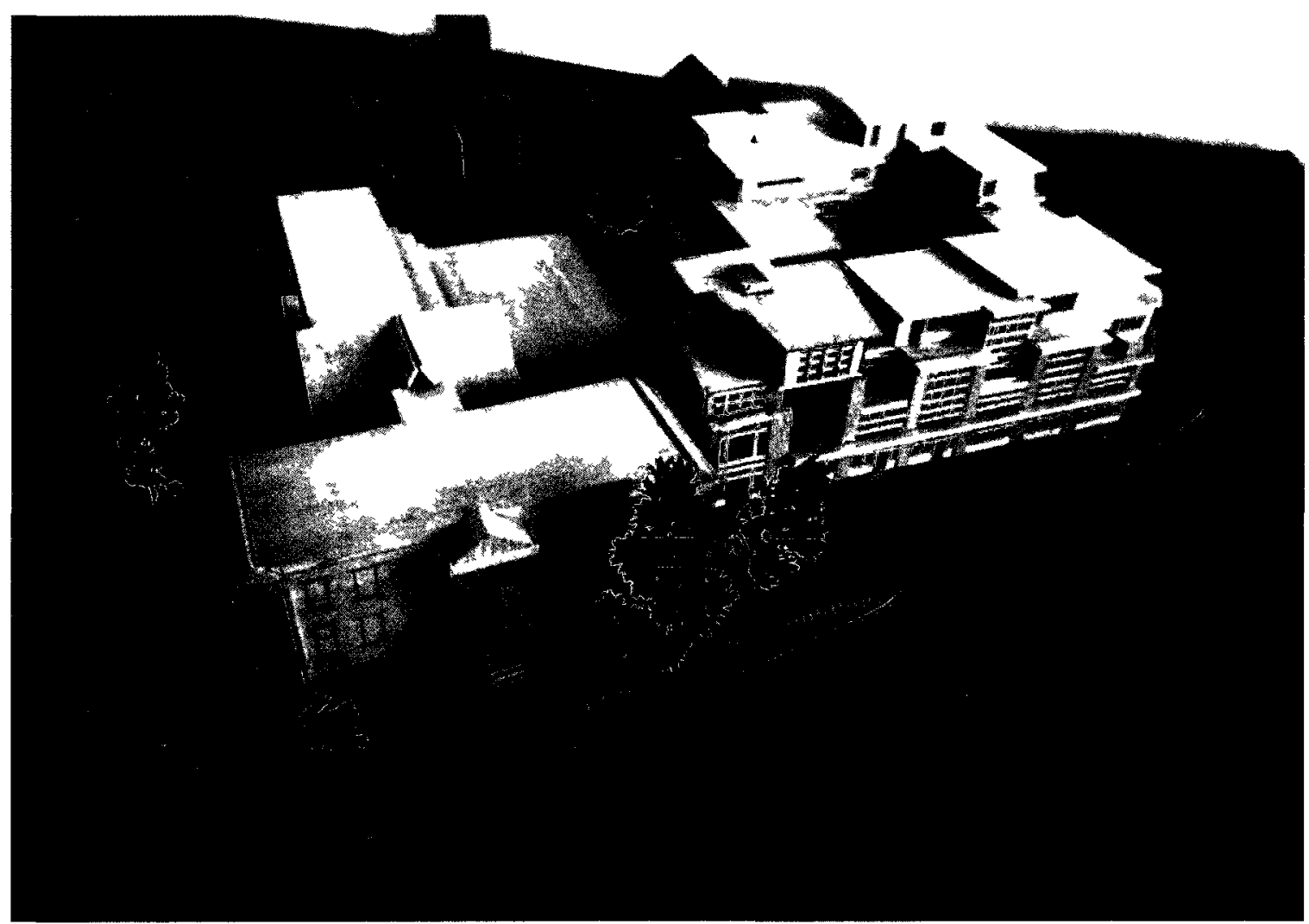

IIIustration 94 Wellington Street view 


\section{List of Illustrations}

All images by author unless otherwise stated.

Frontispiece

Illustration 1.

The Royal Edward

Illustration 2.

Drywall framing detail in living room

Illustration 3.

Sun room, windows above chairs lead to dining room

Illustration 4.

The Bristol, ground floor plan

(Plan courtesy of Tartan)

Illustration 5.

The Beckwith, ground floor, looking from family room

Illustration 6.

Nook in childrens bedroom

Illustration 7 .

The Oriole, ground floor plan

(Plan courtesy of Tamarack)

Illustration 8.

Scale model of domicile development, hom

Illustration 9.

Typical floor layout with 11 different units

(Plan courtesy of domicile)

Illustration 10. 01 series suite layout of hom by domicile

(Plan courtesy of domicile)

Illustration 11. $\quad 02$ series suite layout of hom by domicile

(Plans courtesy of domicile)

Illustration 12.

Living space of an '01' suite, nook for a single chair

Illustration 13.

Large dining area of 'O1' suite layout

Illustration 14.

Kitchen, dining and living area of a '02' suite layout

Illustration 15.

Locations of urban houses used in analysis

(Google earth image composition)

Illustration 16. 224 Royal by Hamel Design

Illustration 17.

Basement, ground and second floor plans of 224 Royal Ave.

(Plans courtesy of Hamel Design)

Illustration $18 . \quad$ Niche in back wall behind living area

Illustration 19.

Stone wall in living area and dining area

Illustration 20. Ceiling heights in master bedroom delineate spaces 31

Illustration 21. Light from stairwell brings light into the middle of the house $\quad 31$

Illustration 22. Corner windows help bring light in 32

Illustration 23. Fireplace adds a unique feel to the space, and creates discourse 32

Illustration 24. Roof Terrace 33

Illustration 25. 127 Armstrong, by James A. Colizza Architects 33 
Illustration 26. Site plan of 127 Armstrong

(Courtesy of James A. Colizza Architects)

Illustration 27. Open space above closets 34

Illustration 28. View from living space into kitchen 34

Illustration 29. (left) Kitchen with a double height portion, (right) office abov 35

Illustration 30. Interior window in kitchen 35

Illustration $31 . \quad$ Interior stone wall at Taliesin West 49

(Hess, Alan, Frank Lloyd Wright, and Alan Weintraub. Frank Lloyd Wright : The

Houses. New York : London: Rizzoli ;, 2005. Pg. 255,

Photographer: Alan Weintraub)

Illustration $32 . \quad$ Living room at Taliesin West

(Hess, Pg. 254, Photographer: Alan Weintraub)

Illustration $33 . \quad$ Falling Water $\quad 50$

(Hess, Pg. 242, Photographer: Alan Weintraub)

Illustration 34. Falling Water Fireplace 50

(Hess, Pg.243, Photographer: Alan Weintraub)

Illustration $35 . \quad$ Villa Linnanmaki 51

(Komanoya, Pg. 103, Photographer: Marko Huttunen)

Illustration 36. Villa Linnanmaki, upstairs 51

(Komanoya, Pg. 108, Photographer: Marko Huttunen)

Illustration 37. Home in the Woods, ground floor plan 52

(Susanka (2000), Pg. 35)

Illustration 38. Home in the Woods, Dining Room

(Susanka (2000), Pg. 37, Photographer: Grey Crawford)

Illustration 39. Home in the Woods, walls as storage and display 52

(Susanka (2000), Pg. 39, Photographer: Grey Crawford)

Illustration 40. Ground floor plan of the Waddel house 53

(Komanoya, Pg. 134)

Illustration 41. Waddell House, addition 53

(Komanoya, Pg. 130, Photographer: Keith Hunter)

Illustration 42. Waddell House, interior views 54

(Komanoya, Pg. 134, Photographer: Keith Hunter)

Illustration 43. Vacation house, (left) upstairs hallway (right) upper floor plan 54

(Susanka (2000), Pg. 142-143, Photographer: Grey Crawford)

Illustration 44. Vacation House, eating area 55

(Susanka (2000), Pg. 146, Photographer: Grey Crawford) 
Illustration $45 . \quad$ Lightıng accentuatıng the eatıng area

(Susanka (1998), Pg 66, Photographer Christıan Korab)

Illustration $46 . \quad$ Lightıng accentuatıng the living area

(Susanka (1998), Pg 67, Photographer Christıan Korab)

Illustration $47 \quad$ Location of Site in Ottawa, Ontario

Illustration 48

(Coogle maps, composite ımage)

illustration 48

Orıgınal 1800's Victorian House

(Left ımage, Photographer Dragana Perusın, Rıght ımage, Fortıeth Annıversary

Pamphlet by the Queen of Most Holy Rosary Church)

Illustration 49

1904 addition

( Left and right ımages, Photographer Dragana Perusın)

Illustration 50

1920's addition

(Left and right images, Photographer Dragana Perusın)

Illustration 51

Interior view of Nave

Illustration 52

Interior view of balcony

Illustration 53

Current buildings on the site

(Bıng maps ımage)

Illustration 54

A view down Wellıngton Street

Illustration 55

Left - The Great Canadian Theatre Company,

Right - The Parkdale market

Illustration 56

A sample of street corner sculptures

(Photographer Justın Van Leeuwen)

Illustration 57

Site plan of proposed design

Illustration 58

Photograph of model, Wellington Street view

Illustration 59

Photograph of model, Grant Street view

Illustration 60

Exterior view of new pool addition

Illustration 61

Blow up of basement plan

Illustration 62

Section through community centre and new pool

\section{Front Facade}

Illustration 64

(Photographer Dragana Perusın)

Illustration 65

Interior floor plans and room layout

Entrance of Gallery and Artısts studios $\quad 74$

Illustration 66

Photograph of model, commercial buildıng

Illustration 67

Section through commercial, gallery, and residential space 
Illustration 71

Illustration 72

Illustration 73

Illustration 74

Illustration 75

Illustration 76

Illustration 77

Illustration 78

Illustration 79

Illustration 80

Illustration 81

Illustration 82

Illustration 83

Illustration 84

Illustration 85

Illustration 86

Illustration 87

Illustration 88

Illustration 89

Illustration 90

Illustration 91

Illustration 92

Illustration 93

Illustration 94
Fourth floor gallery space perspective sketch, at night

Photograph of model, gallery spaces

77

Axonometric of Artist live/work studio

78

North and East exterior elevations

85

Photograph of model, north east corner

85

Photograph of model, view into interior courtyard 86

Examples of split levels in a unit $\quad 86$

Axonometric of an example unit 1

Axonometric of an example unit $2 \quad 88$

Axonometric of an example unit $3 \quad 89$

Basement plan 93

Ground floor plan $\quad 94$

Second floor plan $\quad 95$

Third floor plan 96

Fourth floor plan $\quad 97$

Front facade (south) and West facade 98

Back terrace between artists studios and residential complex 98

Front entrance and East side of residential complex 99

Interior courtyard 99

$\begin{array}{ll}\text { Grant Street view } & 100\end{array}$

$\begin{array}{ll}\text { Bed and Breakfast } & 100\end{array}$

$\begin{array}{ll}\text { Commercial building } & 101\end{array}$

$\begin{array}{ll}\text { Site overview } & 101\end{array}$

Wellington Street view 102 


\section{Works Cited}

Bachelard, Gaston. The Poetics of Space. Boston: Beacon Press, 1969.

Busch, Akiko. Geography of Home; Writings about Where We Live. New York: Princeton Architectural Press, 1999.

Dickinson, Duo. Small Houses for the Next Century. New York : McGraw-Hill Inc., 1995.

Gardiner, Stephen. Evolution of the House; an Introduction. New York: Macmillan, 1974.

Giedion, S. (Sigfried),. Space, Time and Architecture : The Growth of a New Tradition. $5^{\text {th }}$ ed., rev. and enl. - ed. Cambridge, Mass. : Harvard University Press, 1967.

Hanson, Julienne. Decoding Homes and Houses. Cambridge ; New York : Cambridge University Press, 1998.

Hess, Alan, Frank Lloyd Wright, and Alan Weintraub. Frank Lloyd Wright : The Houses. New York : London: Rizzoli; 2005.

Isenstadt, Sandy,. The Modern American House: Spaciousness and Middle-Class Identity. Cambridge; New York : Cambridge University Press, 2006.

Jackson, Anthony,. Space in Canadian Architecture. Halifax, N.S. : Tech-Press, c1981. Jammer, Max. Concepts of Space; the History of Theories of Space in Physics. 2nd ed. Cambridge: Harvard University Press, 1969.

"Jackson Trails." tamarackhomes.com. Tamarack. n.d. Web. 2 March 2011

Kent, Susan. Domestic Architecture and the use of Space : An Interdisciplinary Cross-Cultural Study. Cambridge [England] ; New York: Cambridge University Press, 1990.

Kirshenblatt-Gimblett, Barbara. "Theorizing Heritage." Ethnomusicology 39.3 (1995): pp. $367-380$.

Komanoya, Rico. Mini House Style. New York, NY: Harper Design, an imprint of Harper Collins Publishers, 2004.

Leaning, John. Hintonburg \& Mechanicsville: A Narrative History. Ottawa, Ontario. Hintonburg Community Association, Inc. 2003. 
Le Corbusier. Towards a New Architecture. London : Architectural Press, 1970-1927.

Le Corbusier. Une Petite Maison, 1923. 6th ed. Zuerich, Switzerland,: Artemis., 1993.

Parr, Joy. Labouring Children : British Immigrant Apprentices to Canada, 1869-1924. Toronto: University of Toronto Press, 1994.

Ricoeur, Paul. "Metaphor and the Main Problem of Hermeneutics." New Literary History 6.1, On Metaphor (1974): pp. 95-110.

Rooke, Patricia T., and R. L. Schnell. Discarding the Asylum : From Child Rescue to the Welfare State in English-Canada (1800-1950). Lanham, MD: University Press of America, 1983.

Ruskin, John,. The Seven Lamps of Architecture. New York : Farrar, Straus and Giroux, 1979.

Rybczynski, Witold,. Home : A Short History of an Idea. New York ; Markham, ON. : Viking, 1986.

Schoenauer, Norbert,. 6,000 Years of Housing. New York : W.W. Norton, 2000.

Susanka, Sarah, and Kira Obolensky. The Not so Big House : A Blueprint for the Way we really Live. Newtown, CT: Taunton Press, 1998.

Susanka, Sarah. Creating the Not so Big House : Insights and Ideas for the New American Home. Newtown, CT: Taunton Press, 2000.

Ven, Cornelis Van de. Space in Architecture : The Evolution of a New Idea in the Theory and History of the Modern Movements. Assen : Van Gorcum, 1980.

Wright, Frank Lloyd, and Bruce Brooks Pfeiffer. Frank Lloyd Wright: Collected Writings. New York: Rizzoli, 1992.

Wright, Gwendolyn. Building the Dream : A Social History of Housing in America. New York: Pantheon Books, 1981. 